\title{
النمو العمراني لمدينة القاهرة في العصر الفاطمي \\ دراسة في الجغرافيا التتاريخية
}

دكتور

إيمان عيد عبد الحميا

مدرس الجغر افيا التاريخية

كلية البنات / جامعة عين شمس الجئن

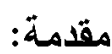

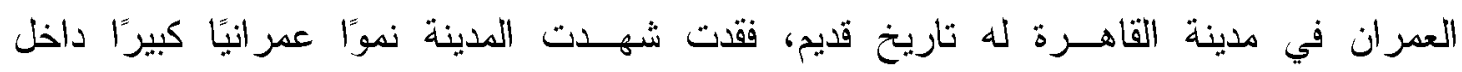

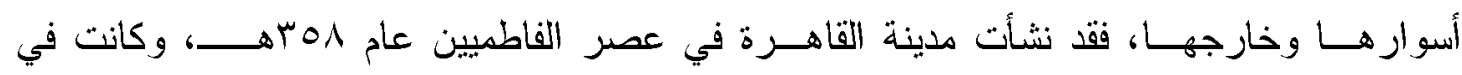

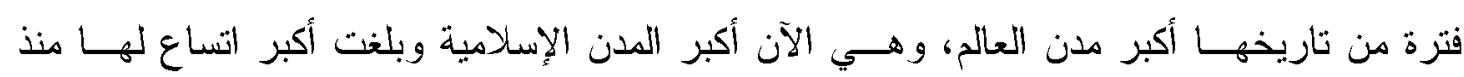

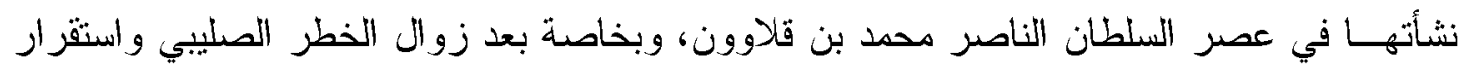

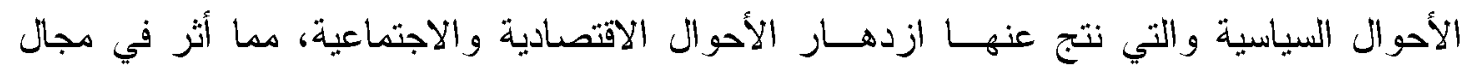

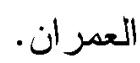

موضوع الار اسة: يتاول البحث النمو العمراني لمدينة القاهرة في العصر الفاطمي، منذ نشأتهــا الأولى على يد

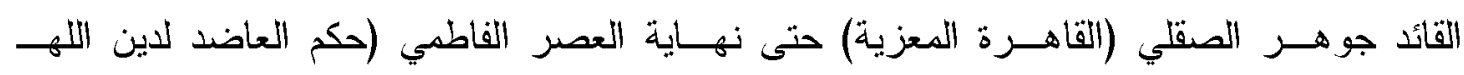

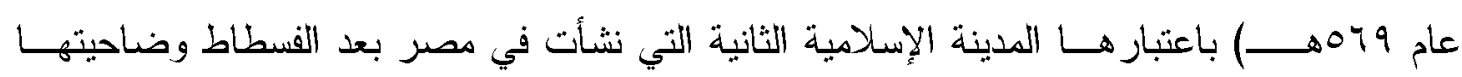
العسكر و القطائح.

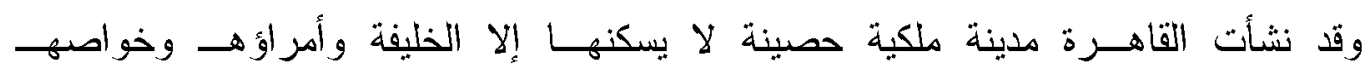
وجندهـ، و لا يسمح للعامة بذخولهـا إلا بإذن ملكي خاص، وقد قامت كحصن شمالي متقدم لمدينة

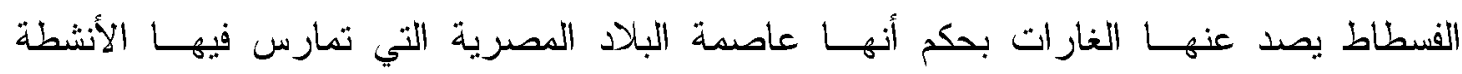

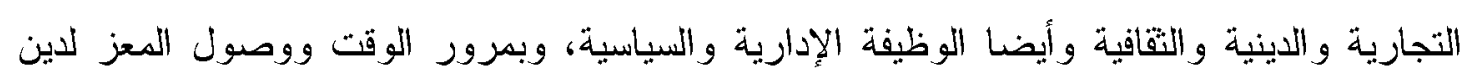

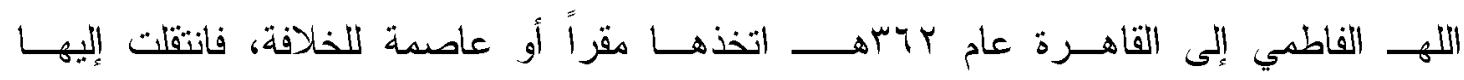

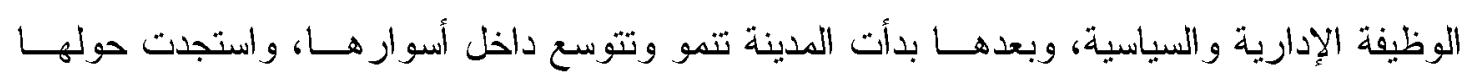

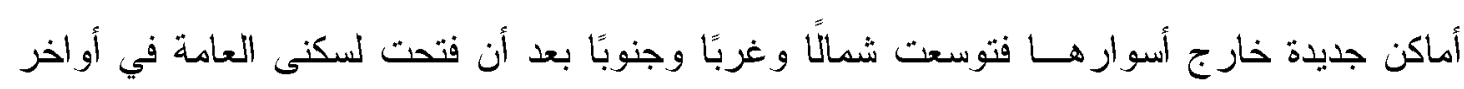
حكم الفاطميين، وبخاصة أيام بدر الجمالي الذي قام بتحصين المدينة وتوسيع أسوارهـا ونـا شمالًا وجنوبًا 
وسنقوم في هذا البحث بلدراسة:

أولًا: خصائص الموضع و الموقح لمدينة القاهرة عند نشأتها الأولى واعتراض المعز لدين الله الفاظمي على اختيار موضع القاهرة.

ثانيًا: الملامح العامة للقاهرة عند النشأة الأولى، ومبرر هذه النشأهاءة، وأسباب تسمية مدينة القاهرة،

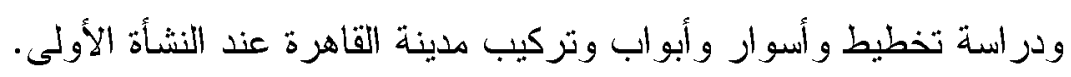

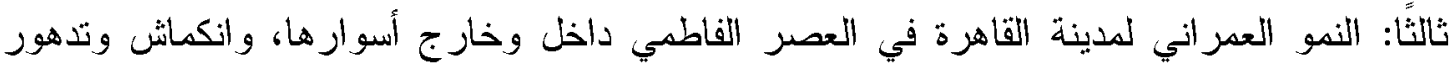
هذا النمو في أو اخر حكم الدولة الفاطمية وأسبابه ونتائجه.

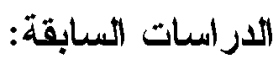

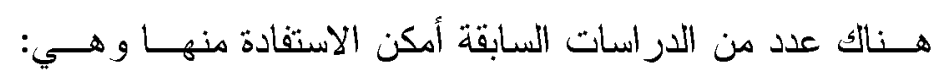

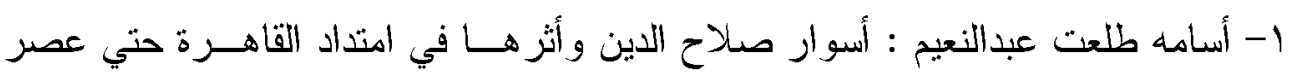

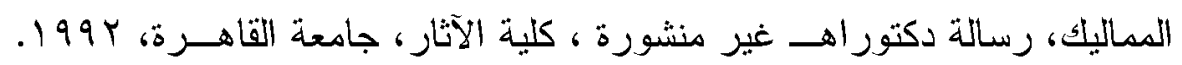

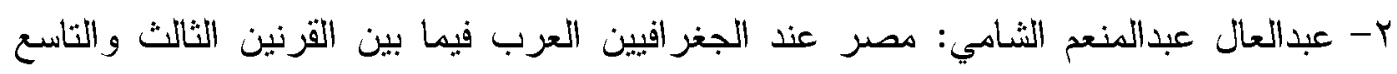
الهـجزي، رسالة ماجستير غير منشورة، قسم الجغرافيا، كلية الآداب، جامعة القاهـرة،

ب- محمد رمزي: الجغر افيا التاريخية لدينة القاهــرة، شبرا وروض الفرج، مجلة العلوم ؛

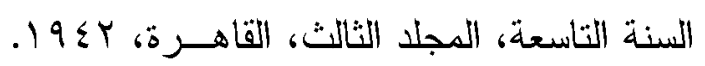
ع- محمد رمزي: الجغر افيا التاريخية لدينة القاهــرة، (عواصم مصر الاسلامية)، مجلة العلوم

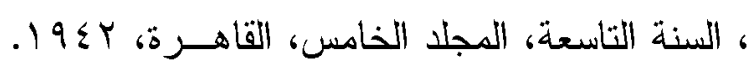

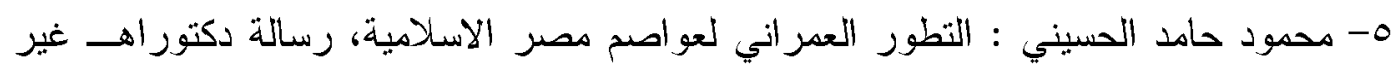

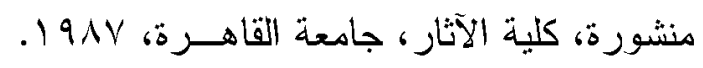

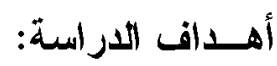
1- استرجاع الصورة الجغر افية العمر انية الكاملة لمدينة القاهـرة، أى دراسة الحاضر التاريخي الأي كان قائما منذ عدة قرون ورسم الصورة الجغر افية كاملة.

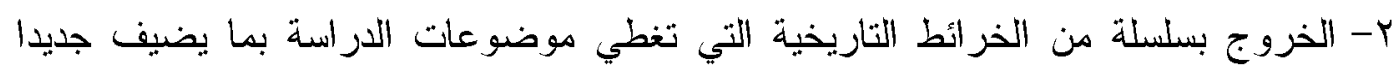

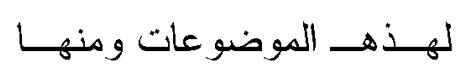

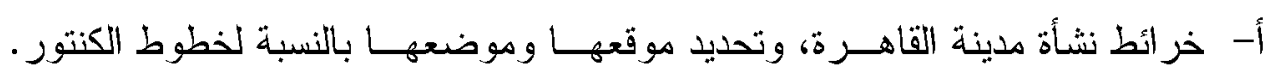
ب-خز ائط خاصة بنمو المدينة عمرانيا في العصر الفاطمي داخل وخارج الأسوار. 
منهــج الدراسة:

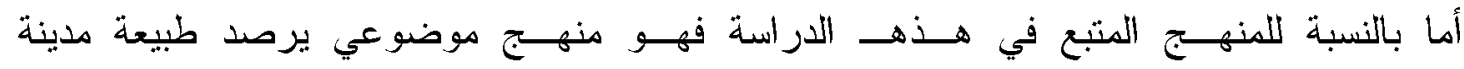

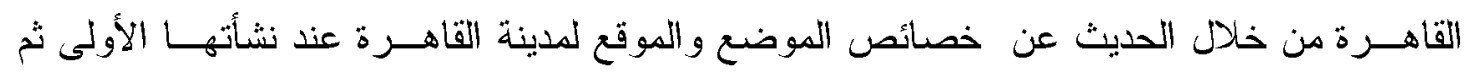

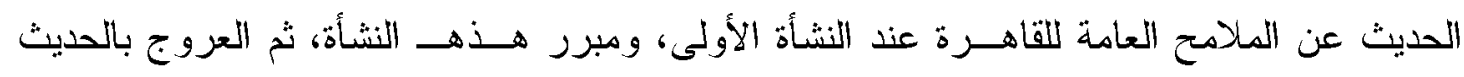

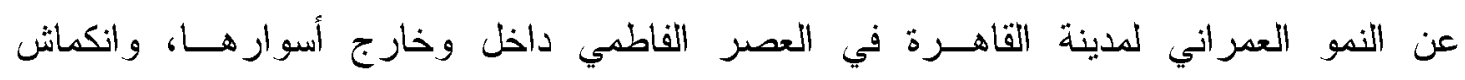
وتدهــور هـــا النمو في أواخر حكم الدولة الفاطية وأسبابهـ ونتائجهـ، كما استخدم الباحث

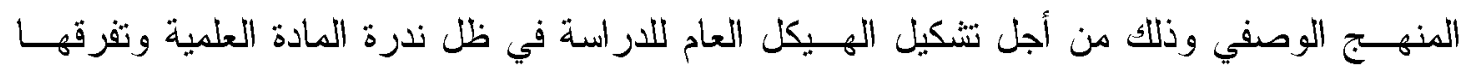
في شذرات دقيقة. أيضًا استخدم الباحث الكنهـــ التاريخي في تتبع نمو هدينة القاهــرة قبل و أثناء وفي نهـاية عصر الفاطميين، للتعرف على العو امل التي ساعدت على ازدهـــار وتدهــور المدينة.

أولاً خصائص الموضع والموقع: 1- إئص الموضع: وعن تلك الخصائص التي كان عليها موضع مدينة القاهرة عند قدوم جوهرة الصقلي عام

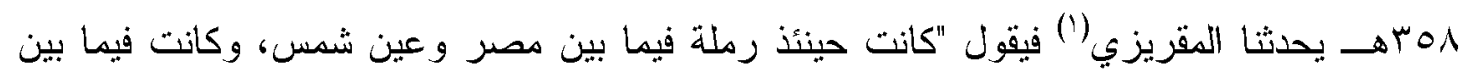

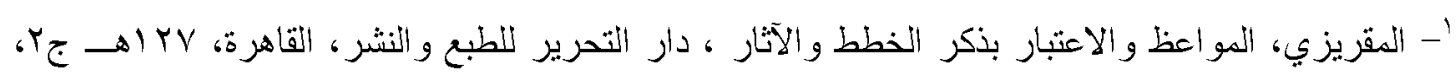

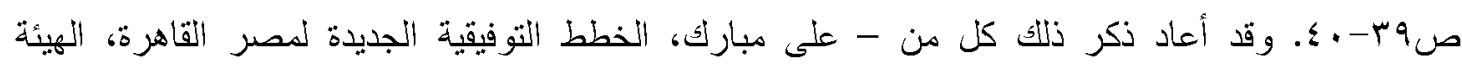

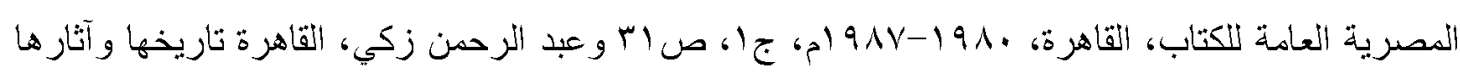

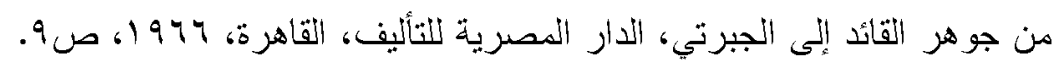

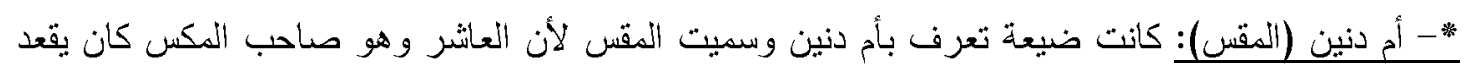

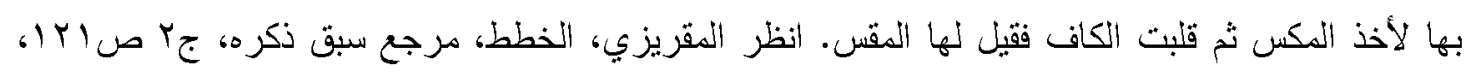

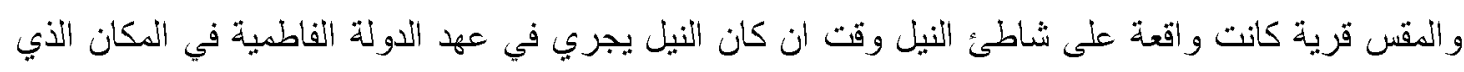

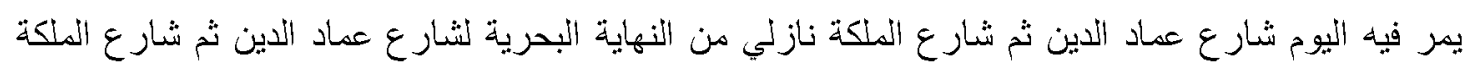

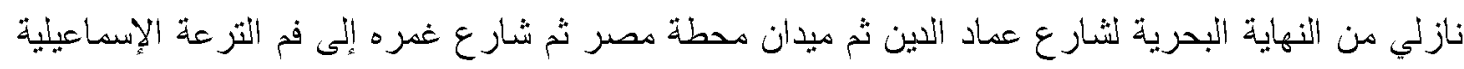

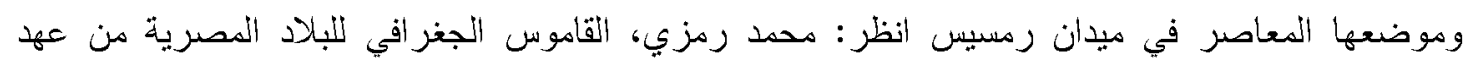

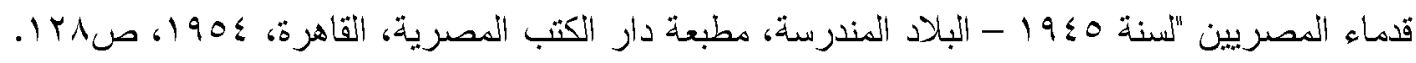

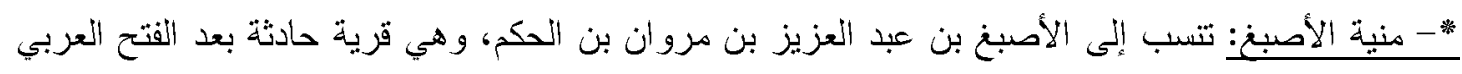

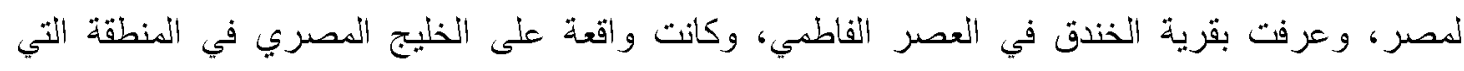


الخليج المعروف في أول الاسلام بخليج أمير المؤمنين وبين الجبل الأحمر. وكان الظليج الذذكور

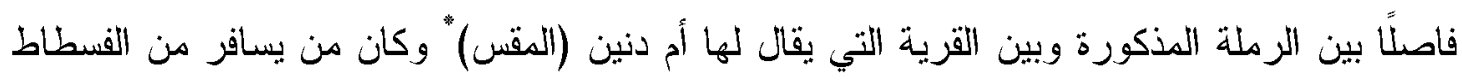

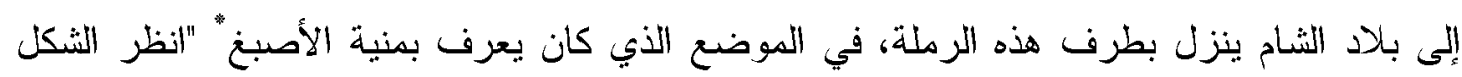

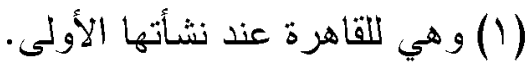

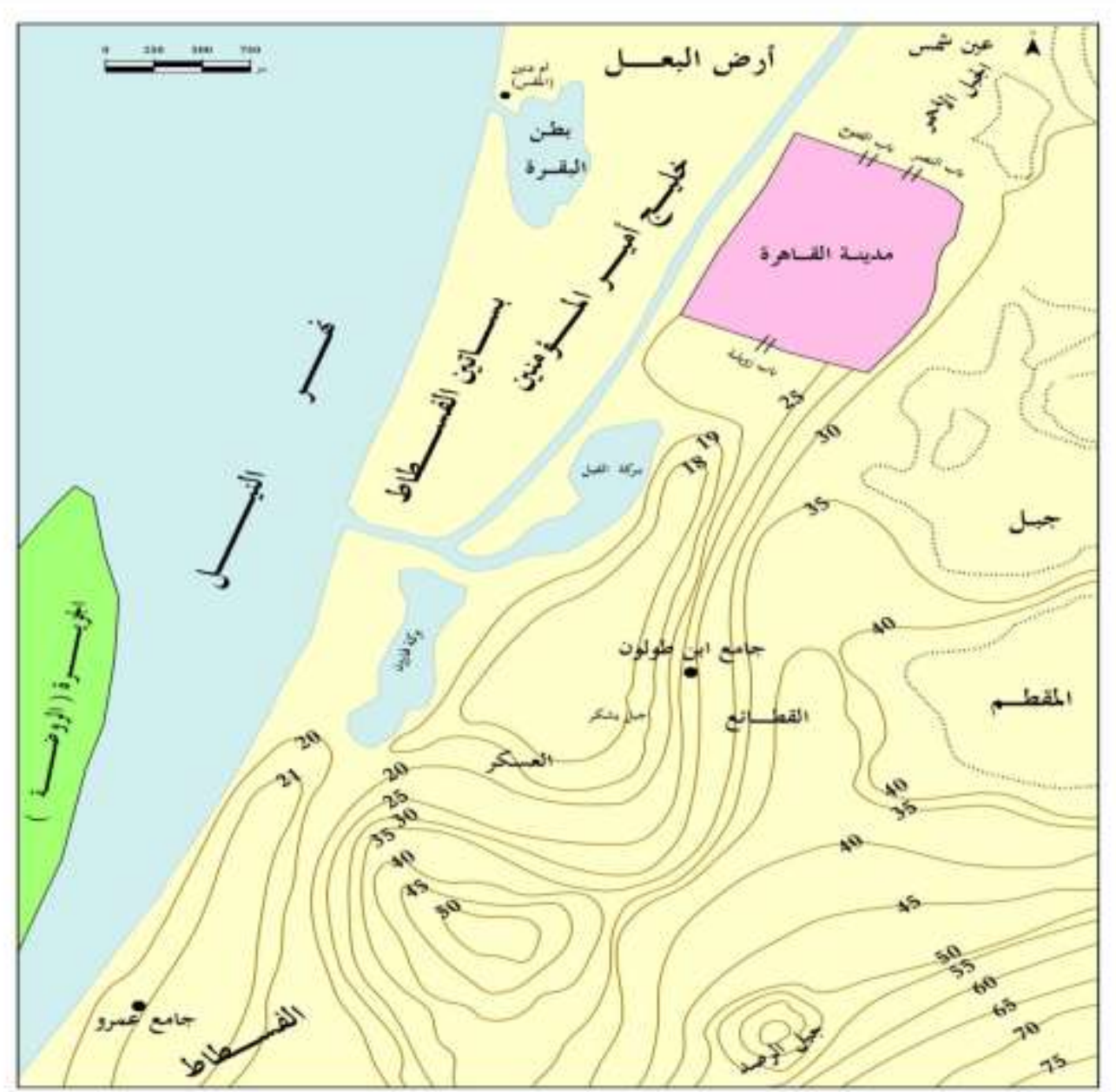

المصدر :كريزويل، القاهـرة النشأة و التطور، مجلة الجمعية الجغرافية، المجلد

|

شكل(1) موقع مدينة القاهــرة في عصر الفاطمبين

يتوسطها الأن دير الملالك البحري بين محطة الدمرداش و الز اوية الحمراء ـ البلاد المندرسة، مرجع سبق

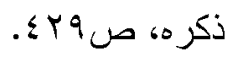


ويضيف المقريزي(') عن موضع القاهرة عند نشأتها الأولى فيقول "ولم يكن عند نزول جوهر بهذه

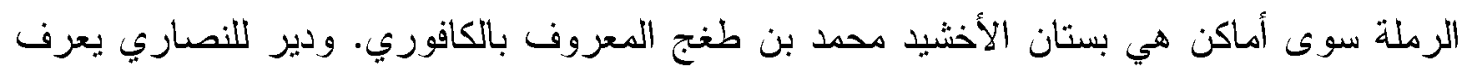

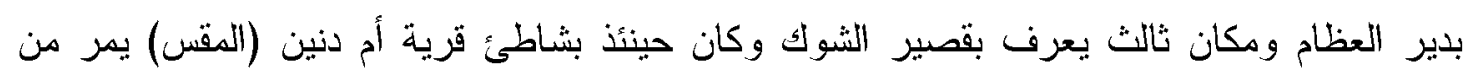

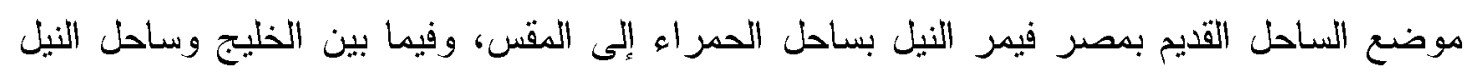

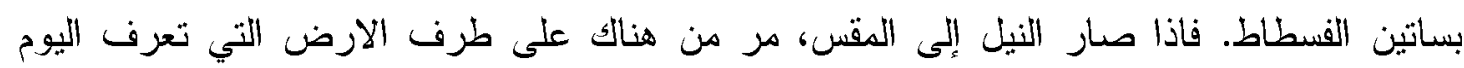

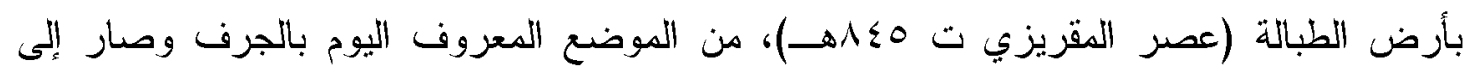

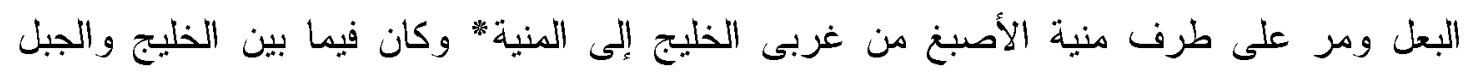

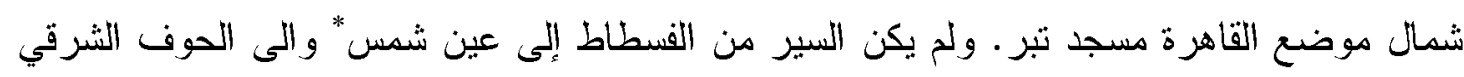

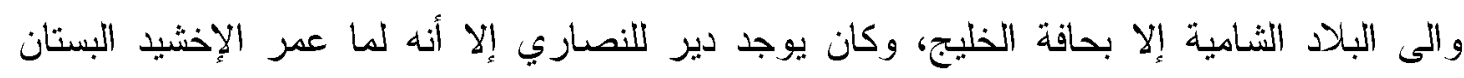

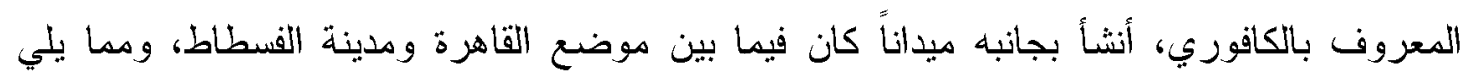

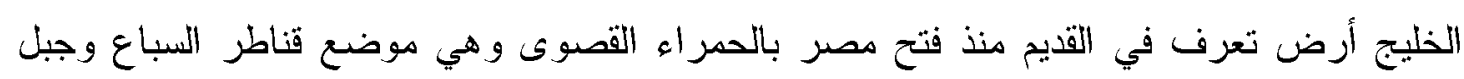
يشكر ، حيث يوجد الدامع الطولوني".

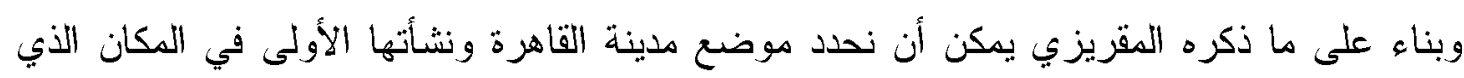

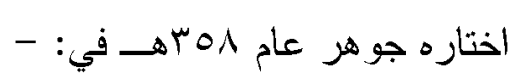
أ. أراضي طرح النهر إلى الثمال من الفسطاط؛ فهذه البقعة كانت رمالا (من أرض طرح النهز

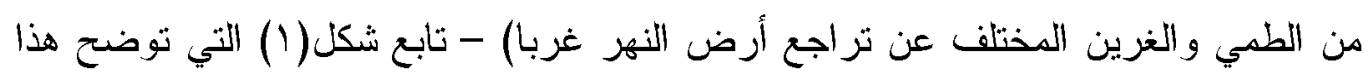

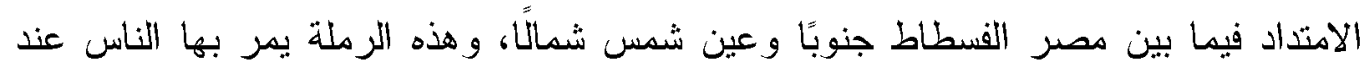

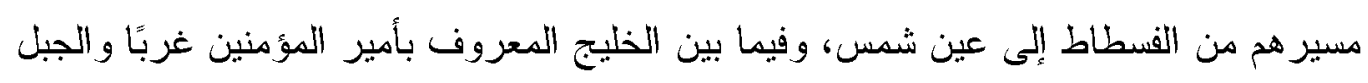
الأحمر شرقًا. ب. لم يكن بهذه المنطقة (الموضع) عمران غير بعض البساتين وأماكن قليلة منها بستان الإخشيد

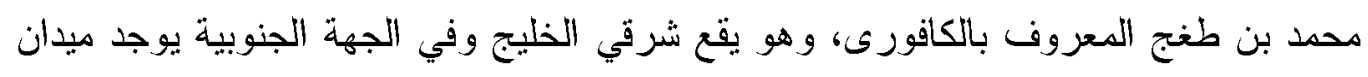

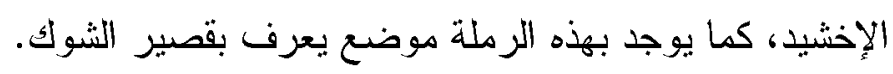
ج. في الغرب يوجد الخليج المعروف باسم خليج أمير المؤمنين.

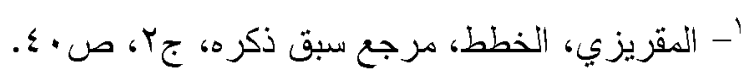

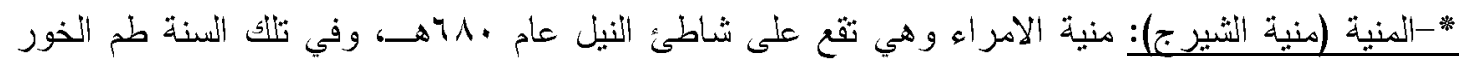

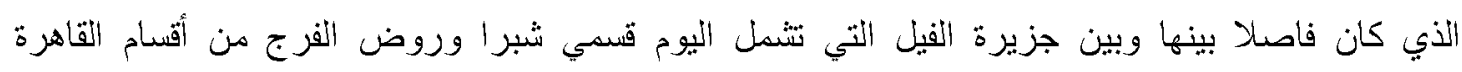

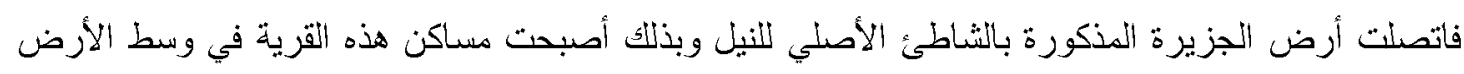

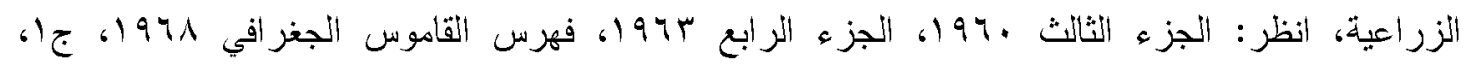
ص10.

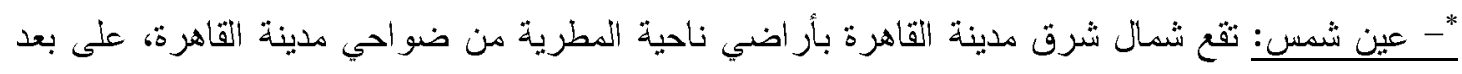

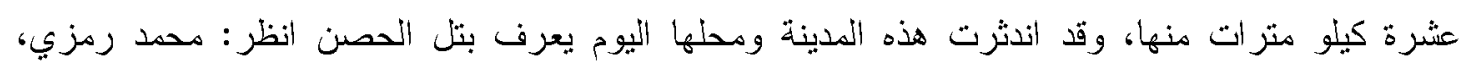

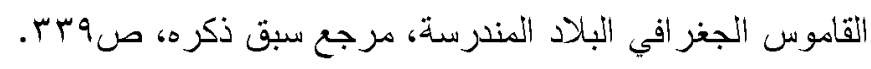


د. تقع قرية أم دنين على شاطئ النهر غربي الخليج، وبين قرية أم دنين والثاطئ الغربي للخليج فضاء لا بناء فيه.

ه. كما توجد قرية منية الأصبغ إلى الثمال مبانشرة من موضع القاهزة، فمن يسافر من الفسطاط

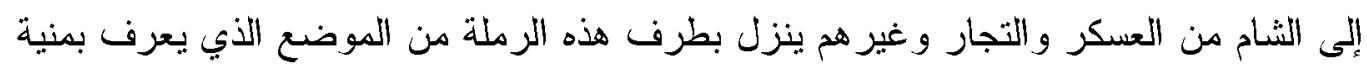

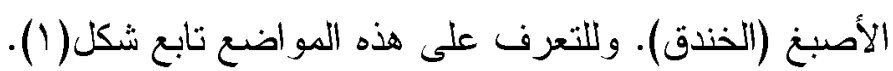

و. كما توجد بداية الدرب السلطاني في هذا الموضع ومنه يتجه الطريق شمالا إلى بلاد الثام الثابع

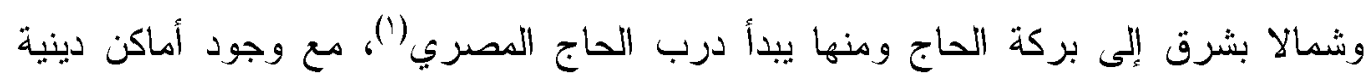

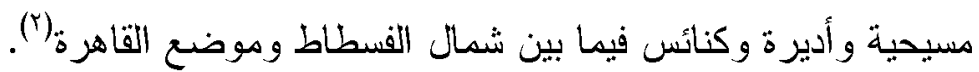
ز. وإلى الثرق من موضع مدينة القاهرة يوجد جبل المقط الذي ينتمي إلى التلال الثرقية

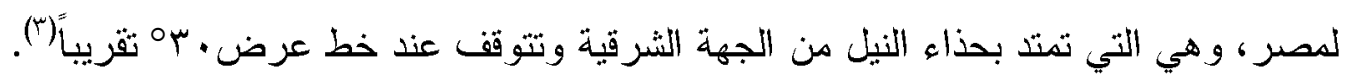

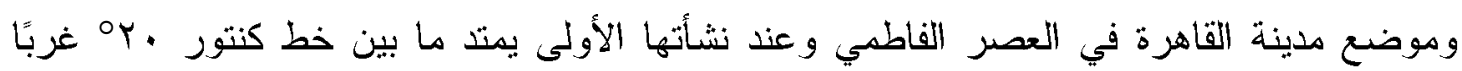

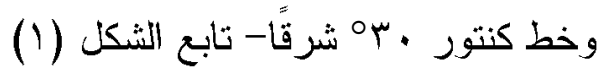
ويتكون جبل المقطم: من عدة هضاب منفصلة تبدو حافتها الغربية والثمالية الغربية التي تطل

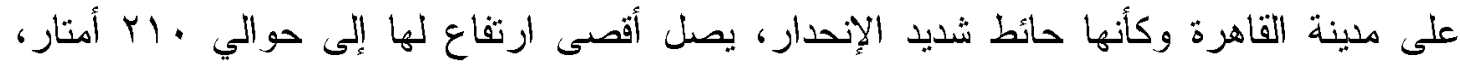

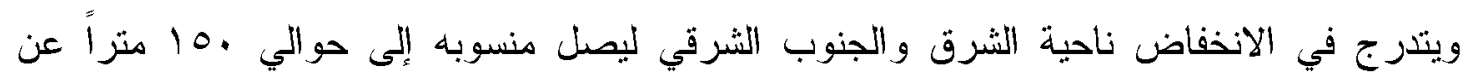

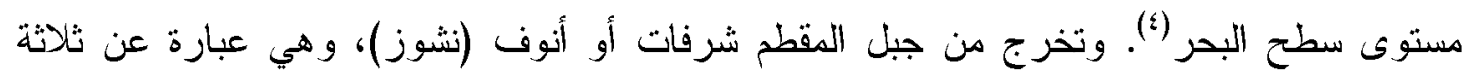

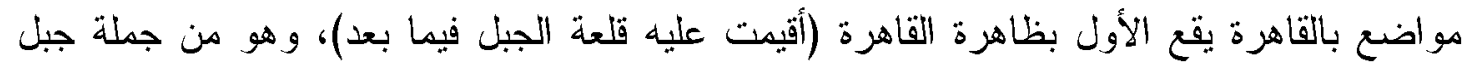

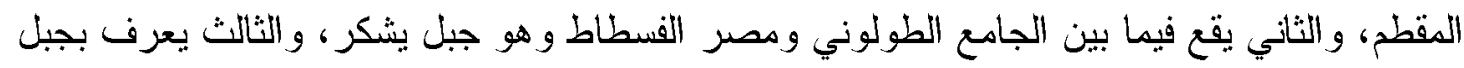

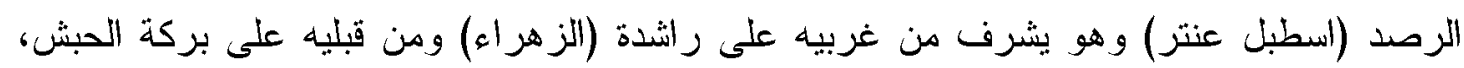

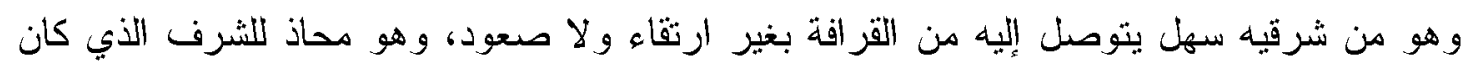

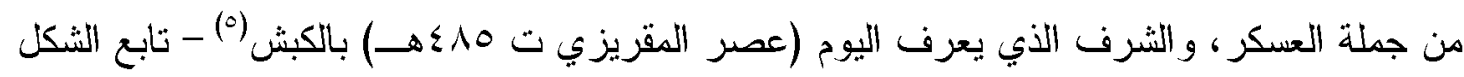

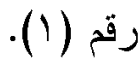

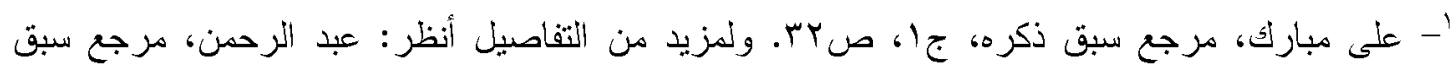

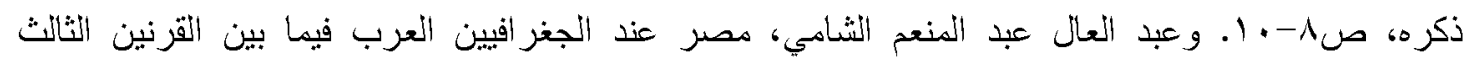

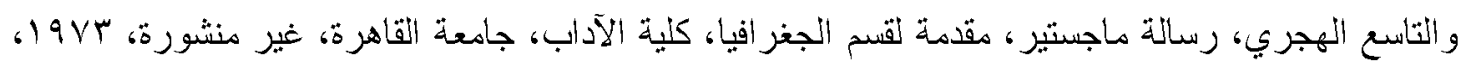

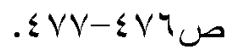

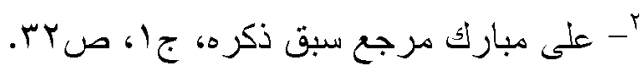

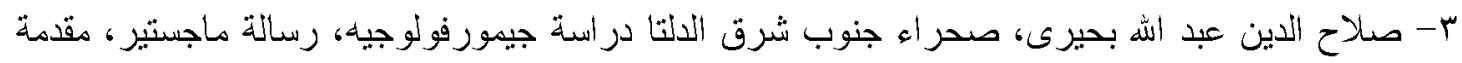

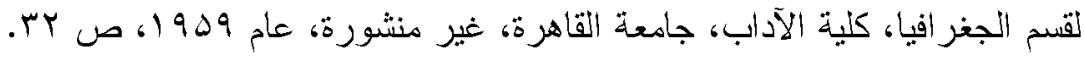

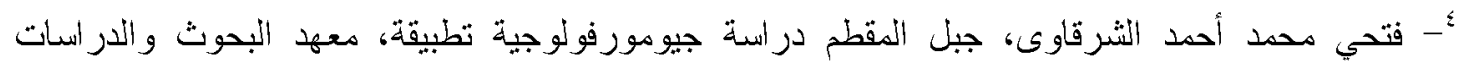

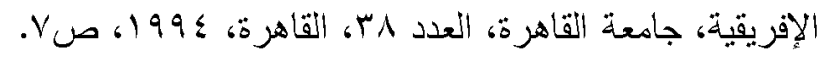

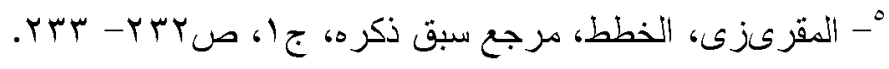


ويقطع هضبة جبل المقطم عند أطر افها الثمالية والثمالية الشرقية كثير من الأودية الجافة

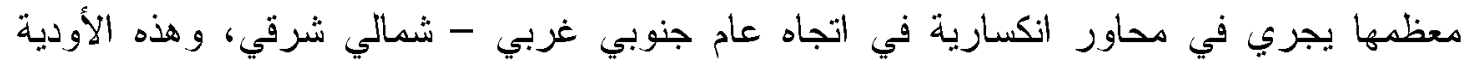

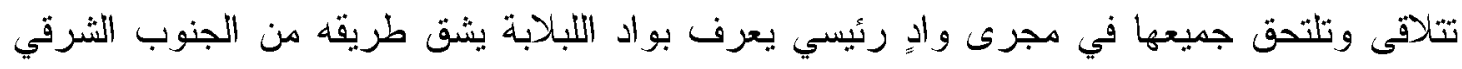

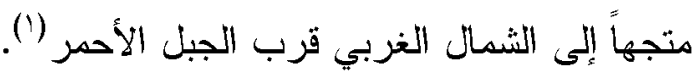

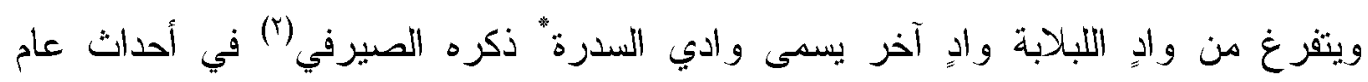

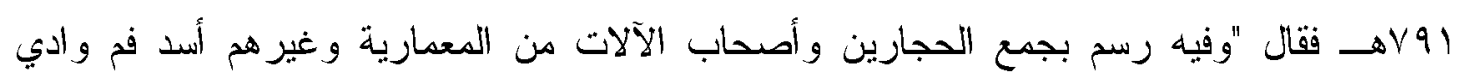
السدرة بجوار الجبل الأحمر".

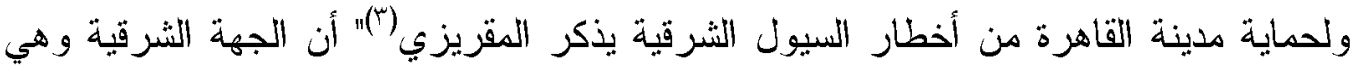

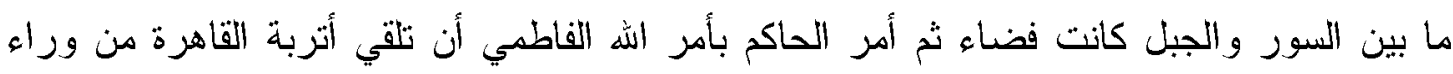

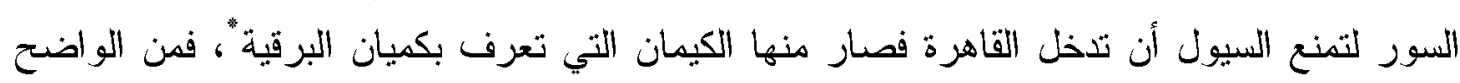

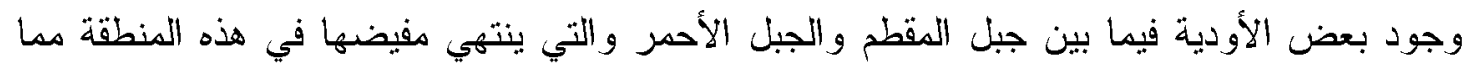

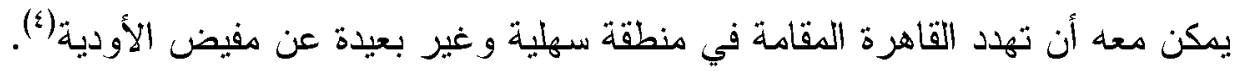

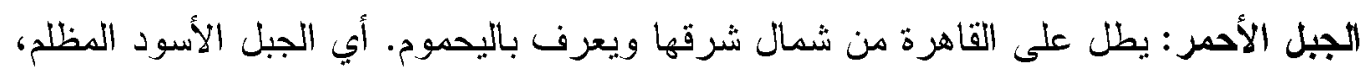

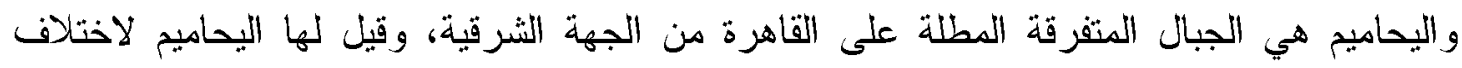
ألو انها('). وقد ذكر ذلك ابن عبد الظاهر (ج).

'- فتحى محمد احمد الثشرقاوب، مرجع سبق ذكره، صو 9.

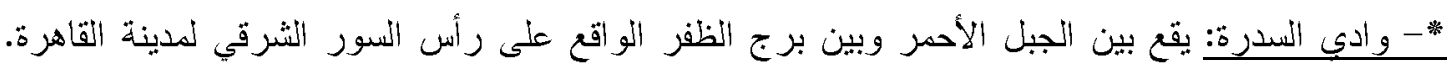

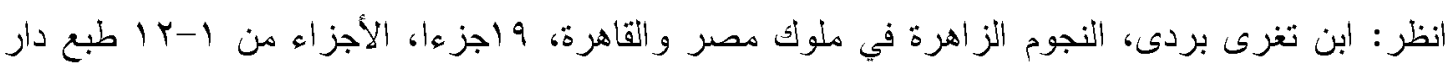

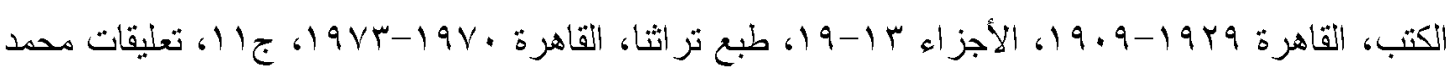

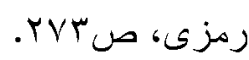
r - الصيرفي، نزهة النفوس والأبدان في نواريخ الزمان، بأجز اه، تحقيق حسن حش، دار الكتب، القاهرة، $19 Y$.

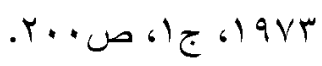

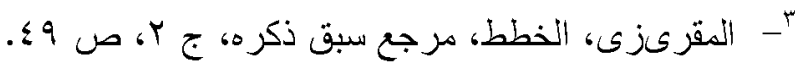

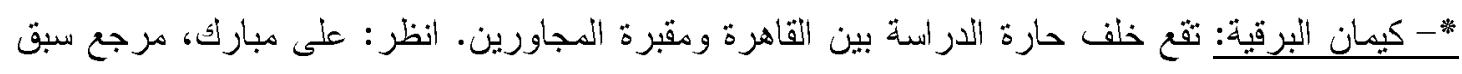

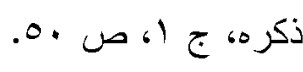

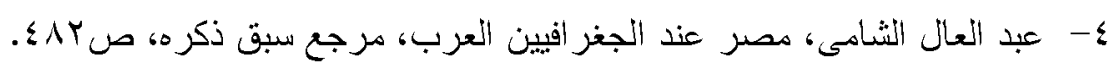

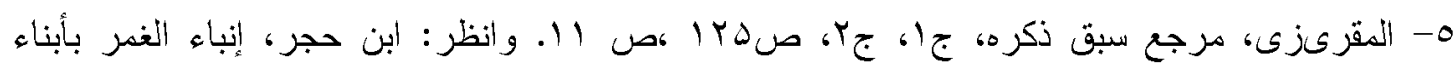
العمر ، بأجز اءه،

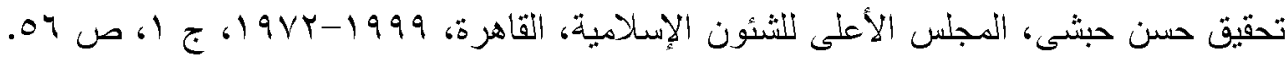

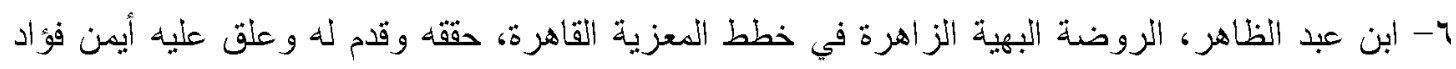

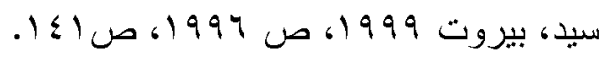


وفي ضوء ما سبق نذكر مزايا موضع القاهرة فقد تو افرت لها مساحة كافية من أراضي طرح

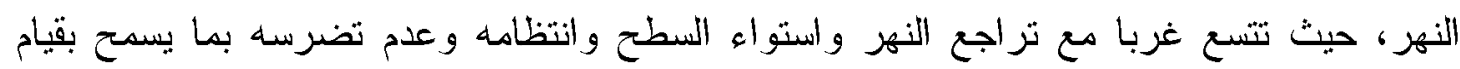

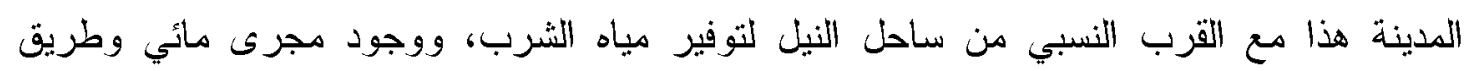

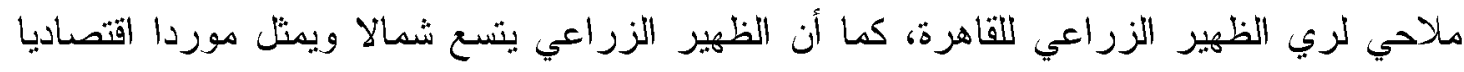
لخدمة سكان القاهرة. و هكذا فإن قيام مدينة القاهرة في الثمال الشرقي للفسطاط في منطقة يبدأ فيها اتساع الوادي يسمح بنمو الدينة مستقبلا، كما أن قيامها أيضا في شمال شرق الفسطاط جعلها في مستقبل الرياح

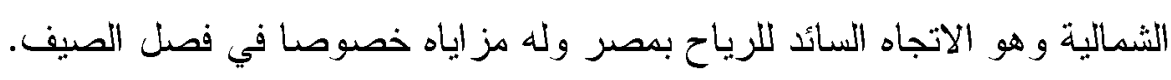

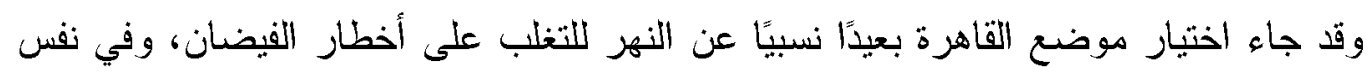

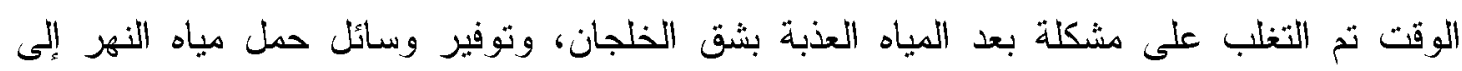

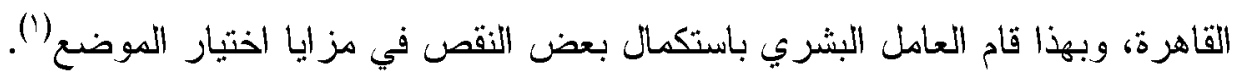

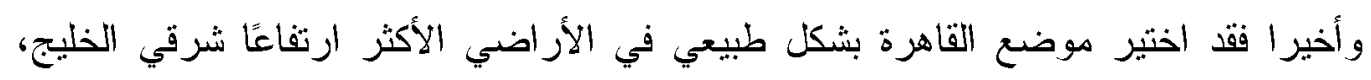

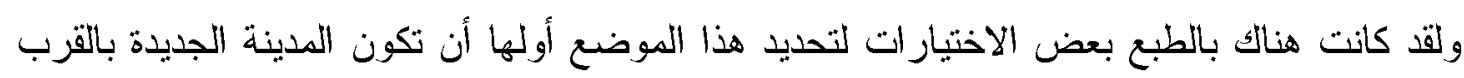

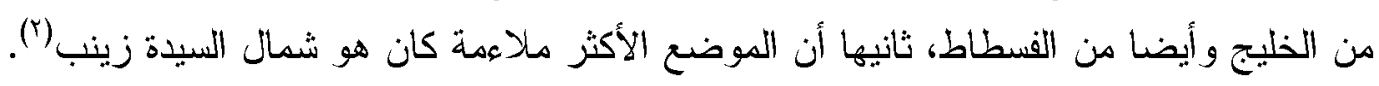

\section{r- خصائص الموقع:}

موقع مدينة القاهرة متوسط بالنسبة للمعدور المصري بين شماله وجنوبه وشرقه وغربه، تخدمه جملة علاقات مكانية مهمة من خلال شبكات من الطرق النهرية والبرية بمصر السفلي و العليا والبحرين المتوسط و الأحمر ("). وتقع القاهرة على مقربة من تفرع دلتا النيل، ويعد هذا الموقع من المواقع الجيدة من الناحية

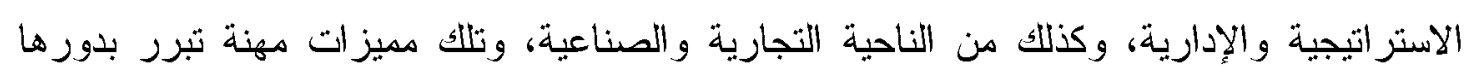

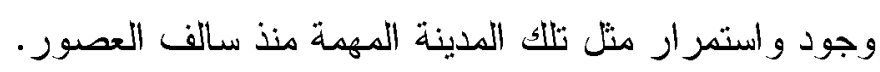
وتقع مدينة القاهرة فيما بين الخليج (خليج أمير المؤمنين والجبل الأحمر)، ويحجزها لئها الخليج

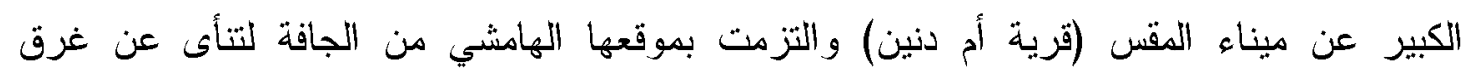
الفيضان (घ) أنير عن

'- عبد العال الثنامى، مصر عند الجغر افيين العرب، مرجع سبق ذكره، صVV . IVrHaswell, C.J.R., Op. cit., P.P., - ${ }^{2}$

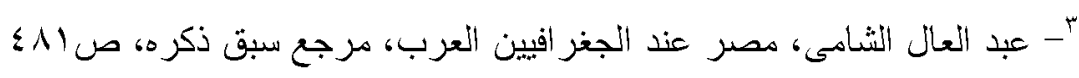

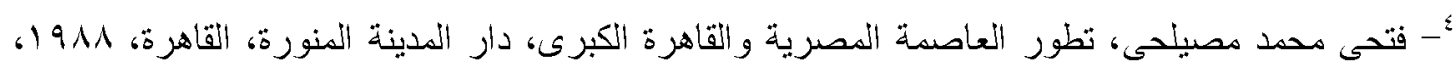


كما أنها تقع على الضفة الشرقية للنيل فهي محصورة بين النيل في الغرب وتلال المقطم في

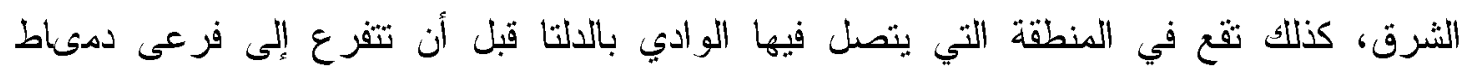

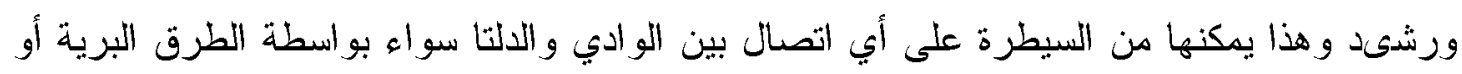

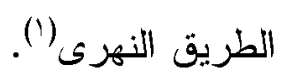

وقد جاءت القاهرة كالفسطاط عند نهاية الوادي وبداية الالتا ومن ثم فهي في موقع متوسط بين

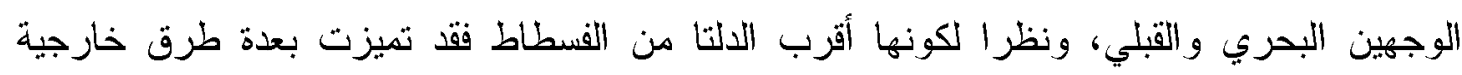

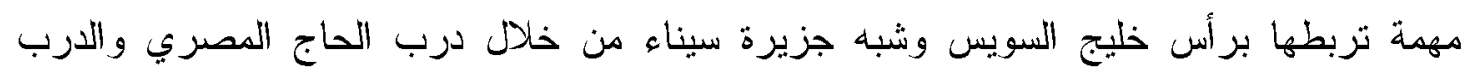

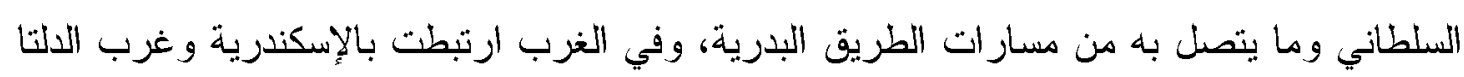
(طريق الحاجر) فضلا عن الطريق الوسطى في جنوب شرق الدلتا ووسطها، وبالصعيد شرقي النيل

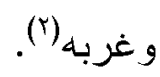

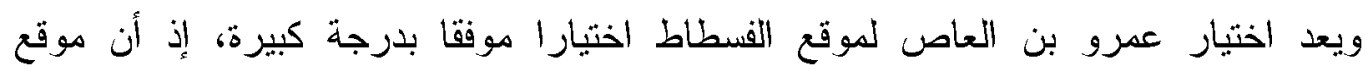

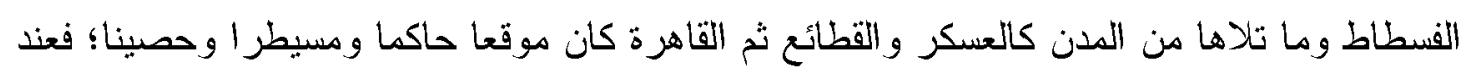
هذا الموقع التلى النهرى حيث تشرف تلال المقطم على التيل توجد خاصرة الو ادي عند التصاله

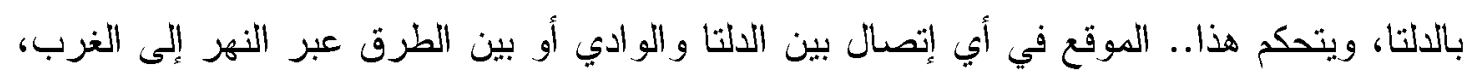

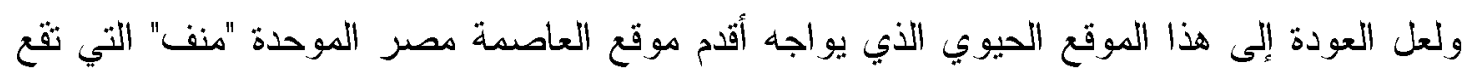

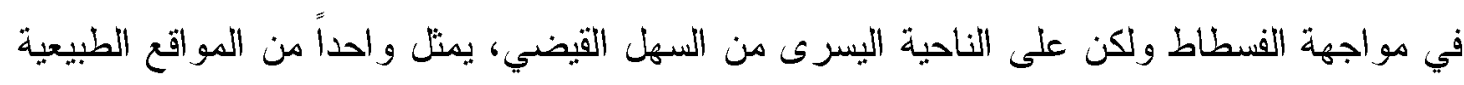

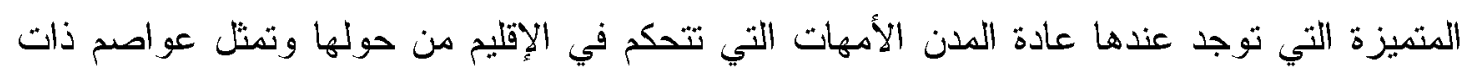
موقع فعال ومؤثر (“). (أما عن اعتراض المعز لدين الله على اختيار موضع القاهرة) يقول ابن عبد الظاهر( (ع) "وما

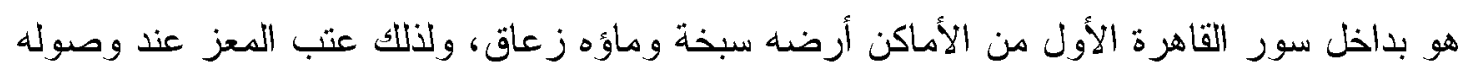

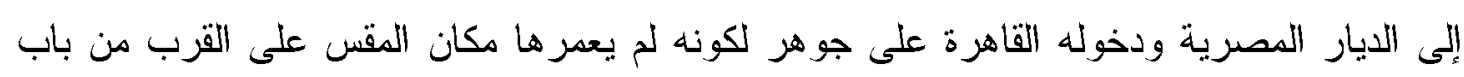

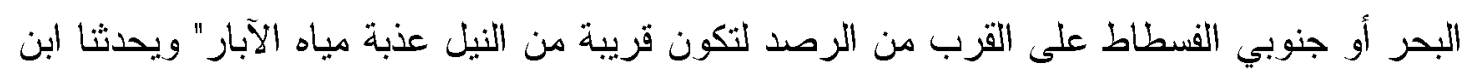

'- أحمد على إسماعيل، دراسات في جغر افية الددن، ط؛، دار الثقافة للنشر والتوزيع، القاهرة، $19 \lambda 1$ ا، ص

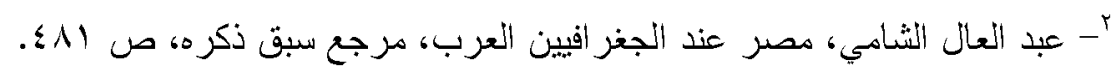

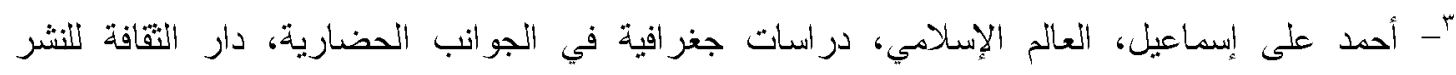
والتوزيع، القاهرة .17)-17. 1999

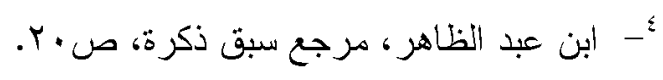


دقماق (') نقلا عن الحافظ جمال الدين اليغموري فيقول "أن المعز لما رأى عمارة القاهرة لم بعجبه

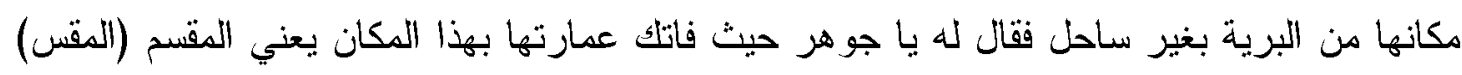

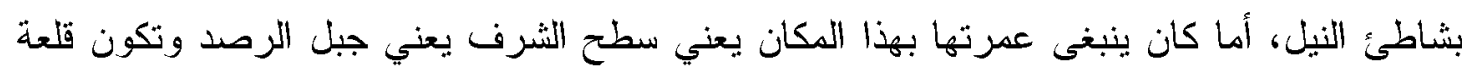

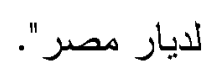

(وللرد على هذا القول نقول) أن المعز لدين الله قد قال هذه الكلمة بعد جولته فيما حول القاهزة

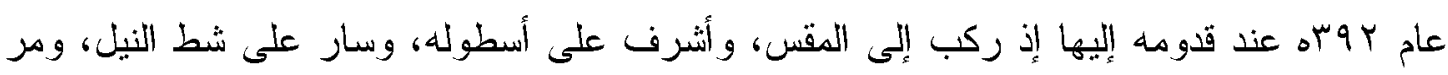

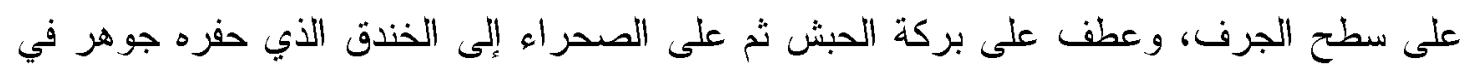
موكب عظيخ وخلفه وجوه أهل البلد (") و هذا القول لايستتد إلى وجود مزايا جغرافية تجعل من المكانين (ساحل النيل وسطح الجرف النه

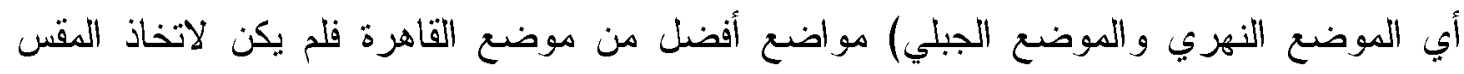

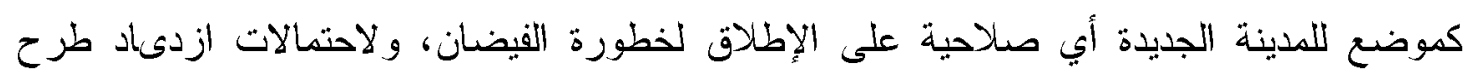

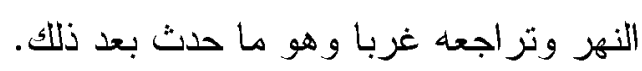

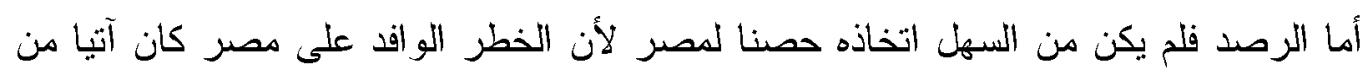

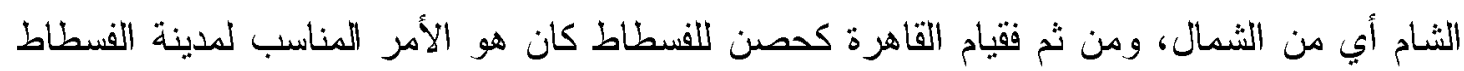

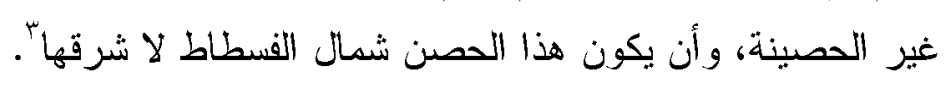
وقد كان الغرض من قيام القاهزة المعزية هو أن تكون حصنة ونهال ومعقلا بين يدي المدينة

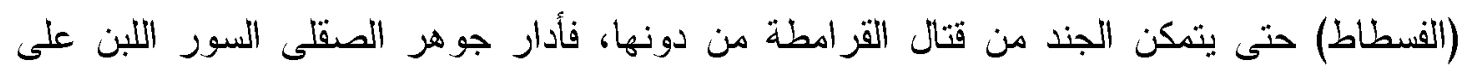

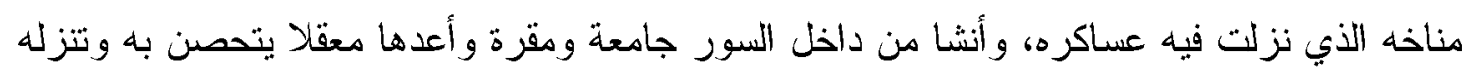

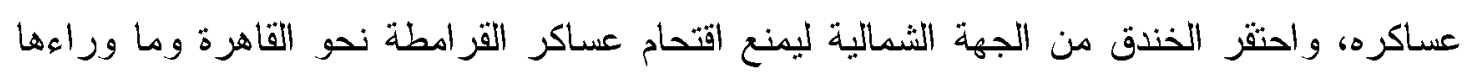
من المدينة الفسطاط؛. وعلى هذا فقد تو افر في موضع القاهرة كل ما يتطلبه الحصن المعتمد على الجبل في الثرق،

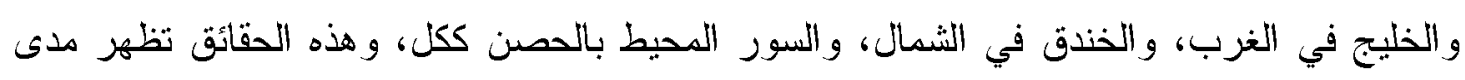

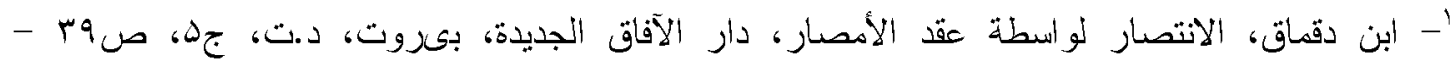

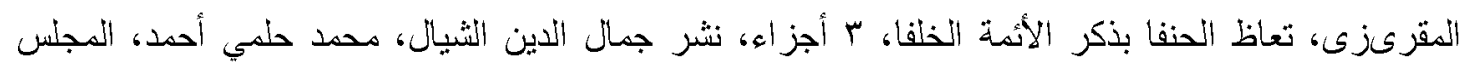

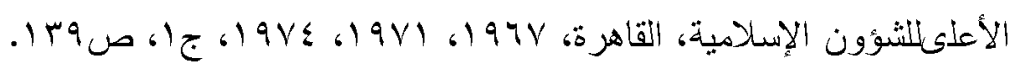

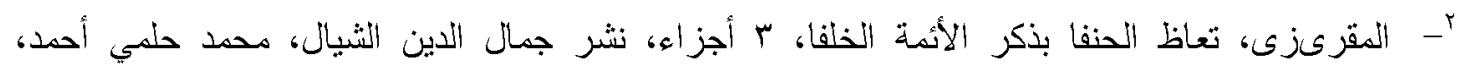

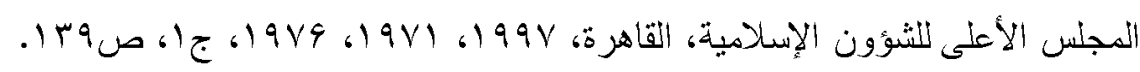

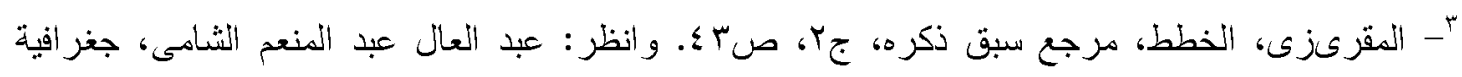

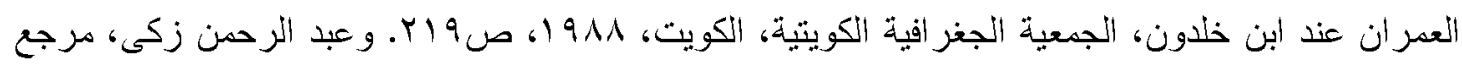
سبق ذكره، ص • ا.

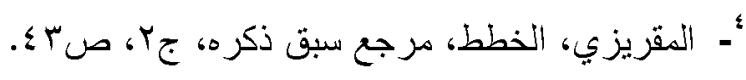


صلاحية الموضع الذي أقيمت فيه القاهرة كحصن، كما أنها من حسن الحظ قد صارت مزايا للموضع نفسه حين صارث القاهرة مدينة سكنية بعد أن كانت في أول نشأتها حصنا للفسطاط فقط'.

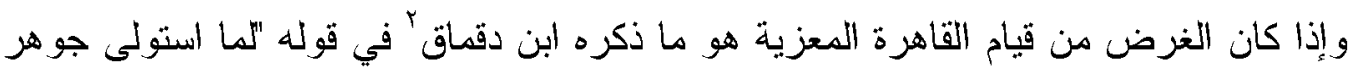
على الايار المصرية بني لسيده القاهزة والقصور ليكون هو وأصحابه وجنوده بمعزل عن العامة

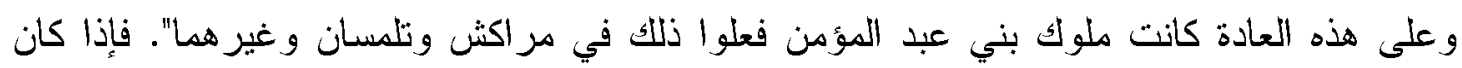

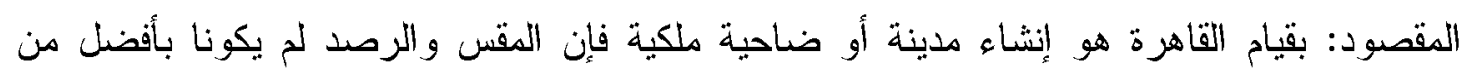
موضع القاهرة بل إن موضع القاهرة يفضلهما.

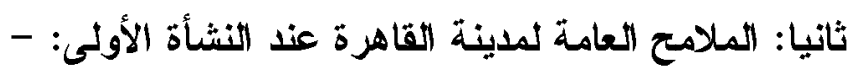

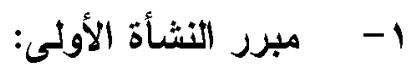

لم تنشأ القاهزة أول الأمر لتكون عاصمة لمصر فالفسطاط كانت العاصمة، وحين اتفق أهلها

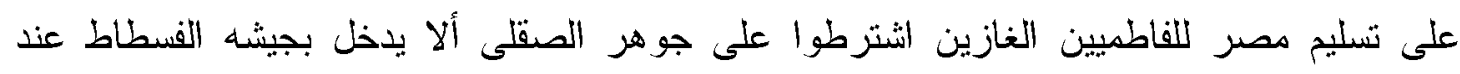

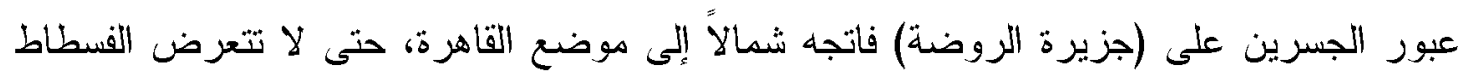
للسلب و النهبَّ. وباعتبار جيش الفاطميين جيشاً فاتحاً غازياً فمن الأجدى في بداية الفتح أن يتخذ له له

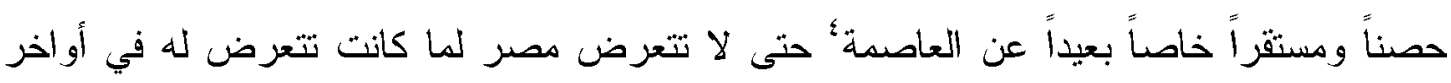
حكم الإخشيدين من هجمات القرامطة، ومن ثم كان هذا الحصن (القاهرة المعزية) في الجهة الثمالية

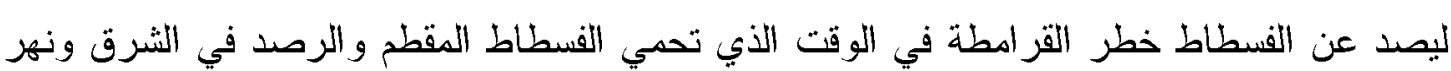
النبل في الغربن. وكان من عادة الدول الحادثة أن تقيم لدولتها الجديدة عاصمة خاصة غير العاصمة القديمة، و هذا أمر متكرر خصوصا أن نظام الدولة الفاطمية مغاير من حيث المذهب الديني لأهل مصر السنيين و هم أصحاب المذهب الشيعي '. ولم يقصد جوهر من إنشاء القاهرة المدينة المحصنة في بادئ الأمر أن تكون قاعدة أو دار خلافة أو منزل ملك، بل اختطها لتكون سكنا للخليفة وحرمه وجنده وخواصه، فنشات القاهرة مدينة

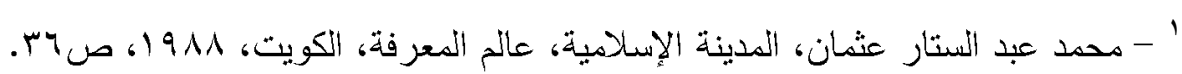

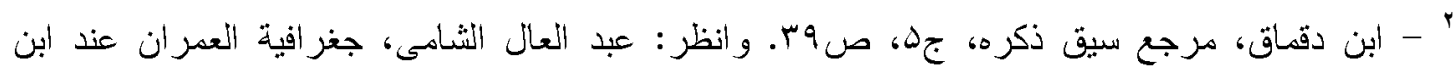

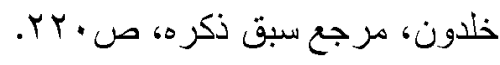

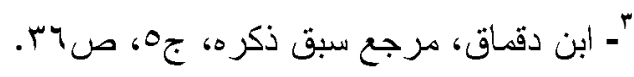

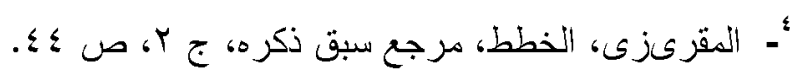

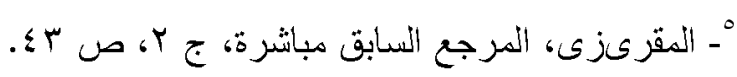

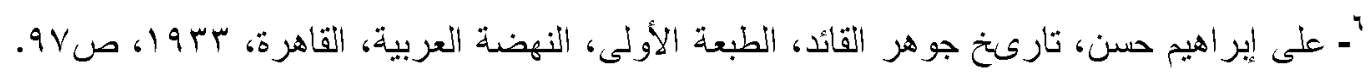


خاصة للاولة الفاطمية الناشئة، واستمرت حينا، بعد قيامها مدينة ملكية عسكرية تتتمل على قصور الخلفاء ومساكن الأمر اءودو واوين الحكومة وخز ائن المال و والسلاح'.

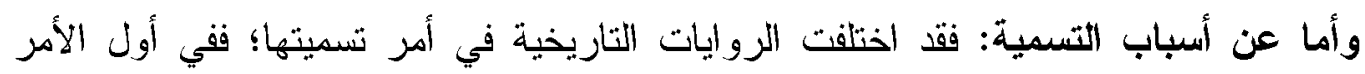

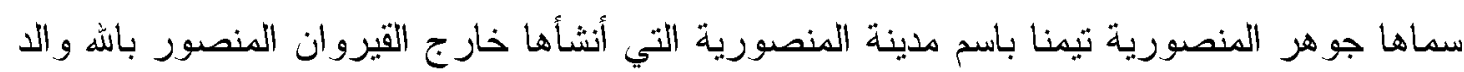

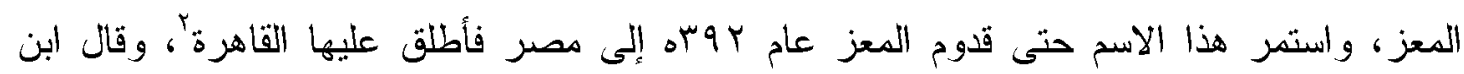

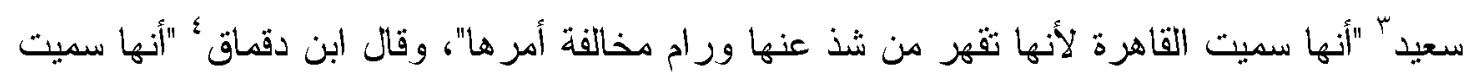

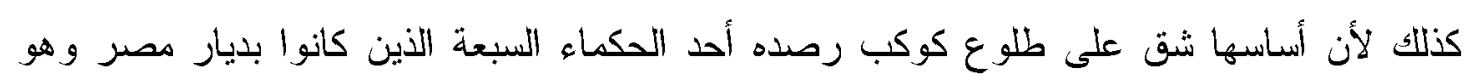
كوكب يقال له القاهر". و المقرىزى وابن تغرى بردى" اجتمعت أقو الهم في تسميتها فقالا "أن القائد جوهر لها أراد

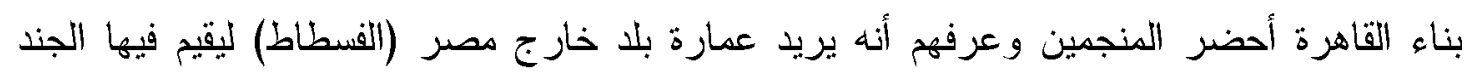

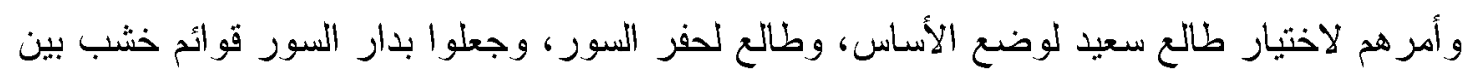

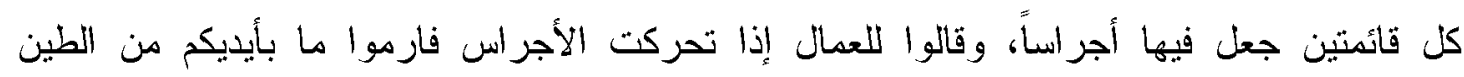

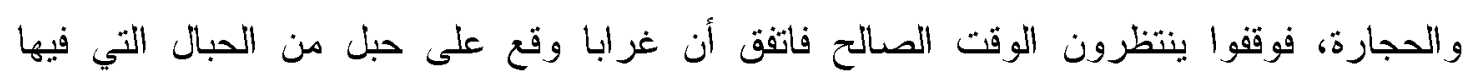

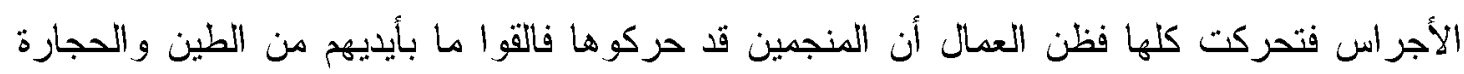

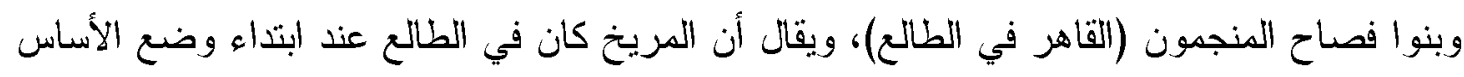
وهو قاهر الفلك فسمو ها القاهرة".

\section{ب- تخطيط مدينة القاهرة (المحزية) عذد نثأتها الأولى:}

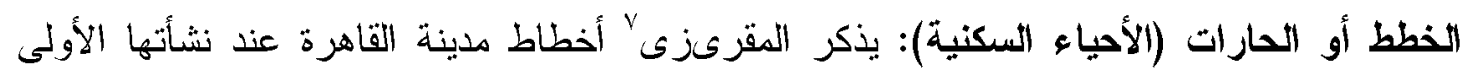

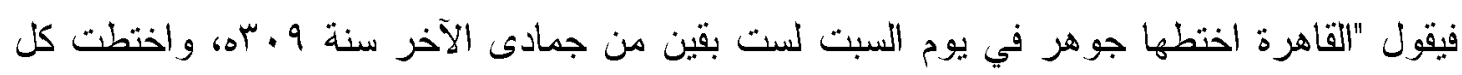

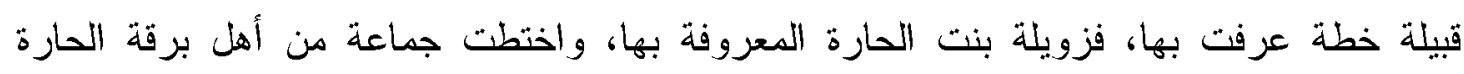

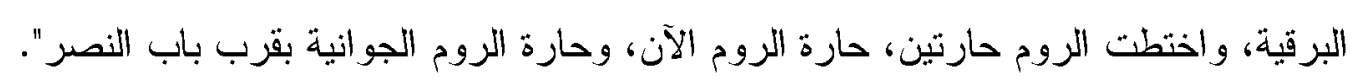

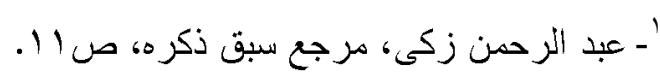

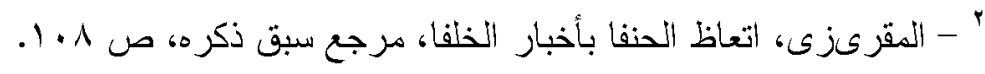

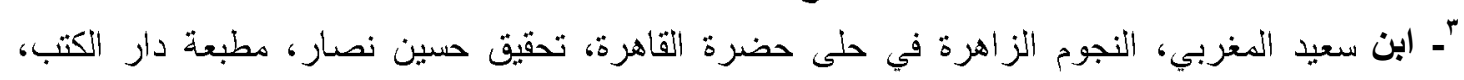

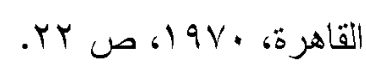

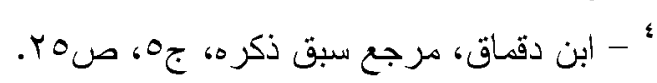

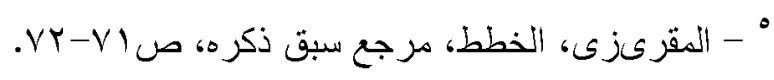

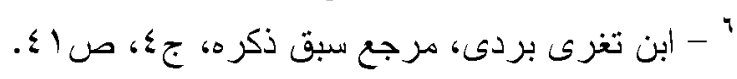

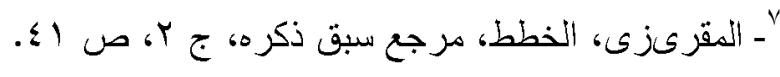


* حارة زويلة أو خطة زويلة: يقول عنها ابن دقماق '"زويلة طائفة من البرير قدموا مع المعز لدين

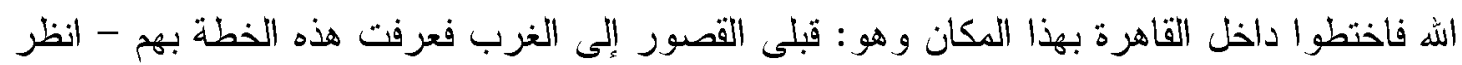

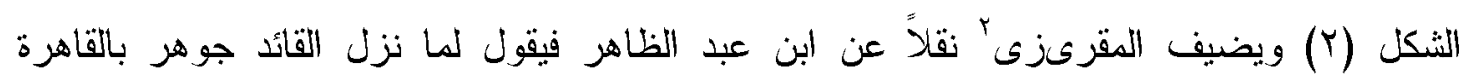

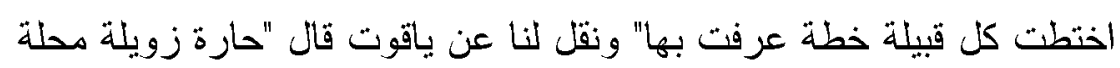

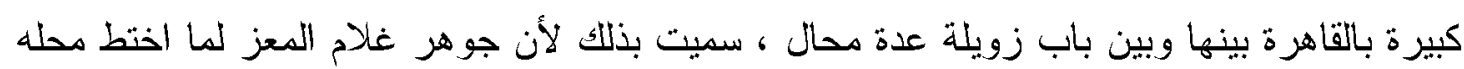
بالقاهرة أنزل أهل زويلة بهذا المكان فتسمى بهم".

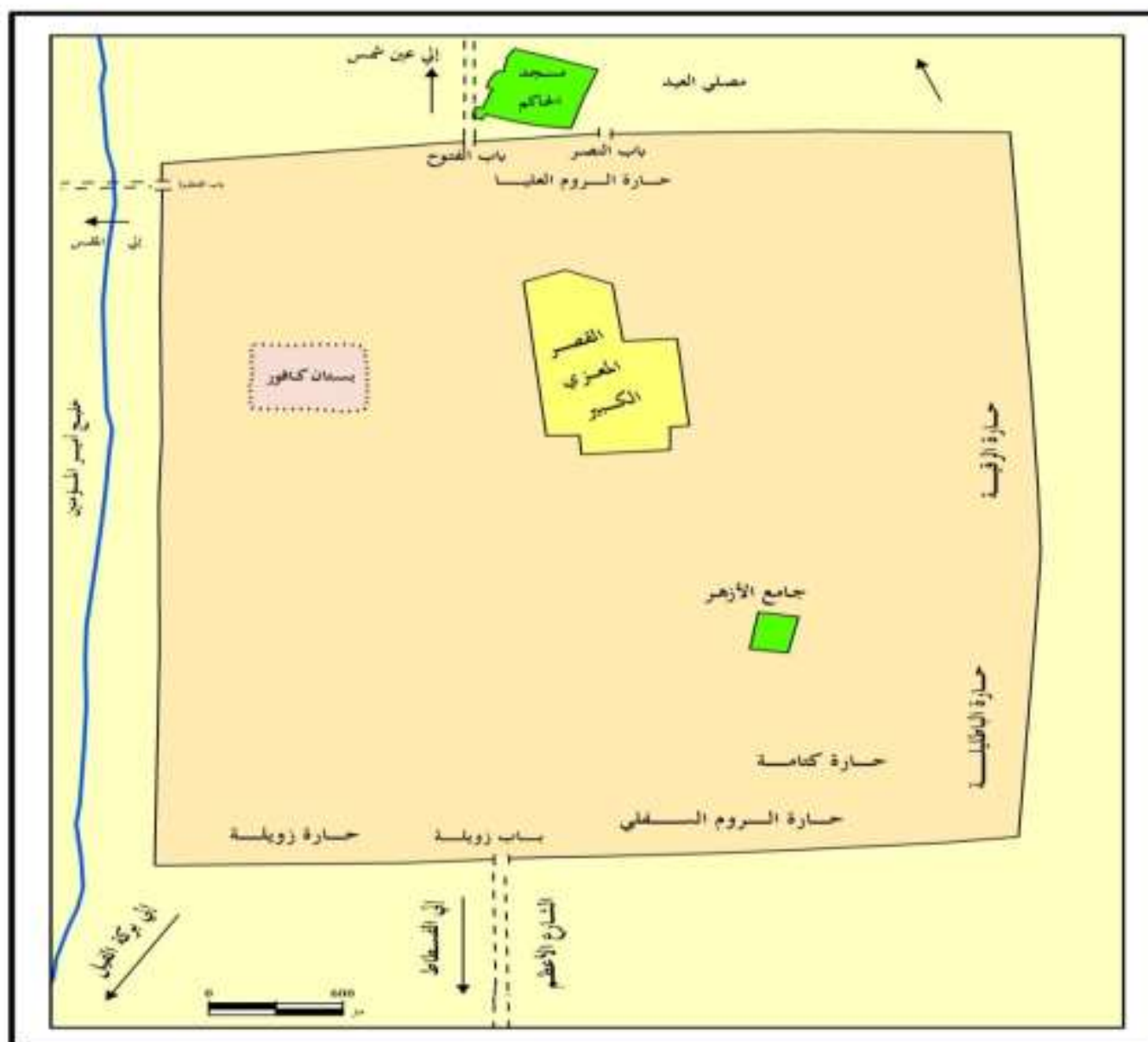

الصصدر : المسبحي،أخباز مصر ـ- تحقيق وليخ ج ميلورد، الهـيئة الدصرية العامة للكتاب،.191 شكل (Y) القاهـرة المززية عند تأسيسهــا مع التعديل

$$
\begin{aligned}
& \text { ' ' - ابن دقماق، مرجع سبق ذكره، جه، صلrه. }
\end{aligned}
$$

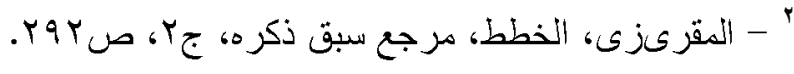


* حارة الباطلية (خطة الباطنية): ذكرها ابن عبد الظاهر'، ويحدثا عنها ابن دقماق ' نقلا عن ابن عبد الظاهر فيقول "منسوبة إلى جماعة من الباطنية قدموا إلى الديار المصرية فنزلوا داخل القاهرة

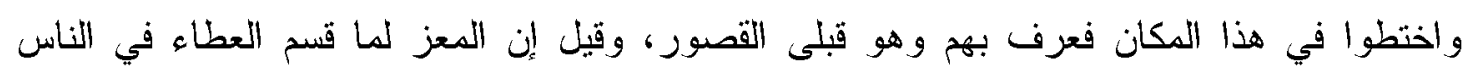
جاعت وطائفة فسألت عطاء فقيل لها فرغ ما كان حاضراً ولم يبق شي فقالوا الحق باطل فسموا الباطلية فعرفت الخطة بهم" - تابع شكل (Y). ويذكر المسبحي بَ في أحداث عام $ه$ اعه فيقول "فأنفذ إليه خلق من العبيد البرقيين والباطلية".

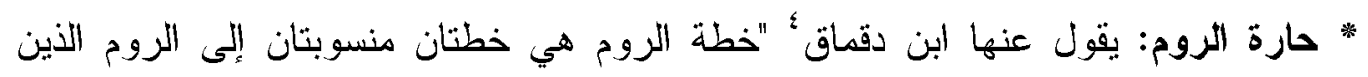

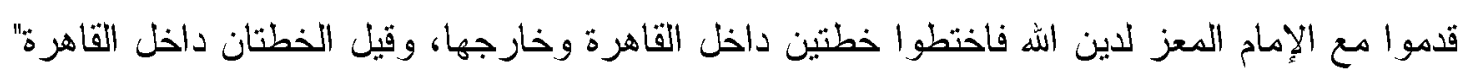
أما المقريزى فيقول عنها نقلا عن ابن عبد الظاهر "واختطت الروم حارتين حارة الروم الآن،

وحارة الروم الجوانية" - تابع شكل (Y). * حارة البرقية (خطة البرقية): يقول عنها ابن دقماق " "منسوبة إلى جماعة من أهل برقة قدموا مع دابع

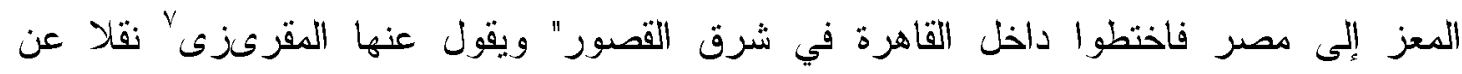
المسبحي "هذه الحارة عرفت بطائفة من طو ائف العسكر في الدولة الفاطمية يقال لها الطائفة البرقية".

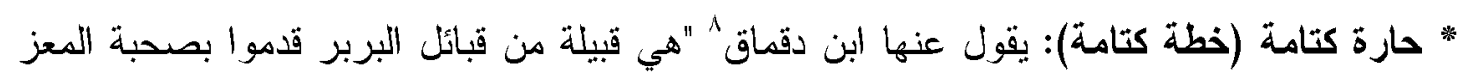
فاختطو إلى جانب الباطلية من القرن فعرفت هذه الخطة بهر" ويقول المقرىزى

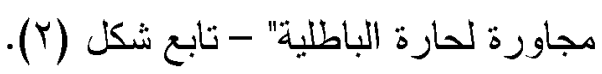

r- أسوار مدينة القاهرة (المعزية) عند نثأتها الأولى:

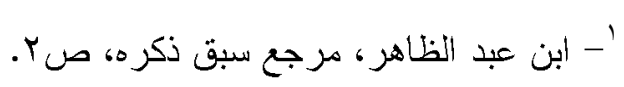

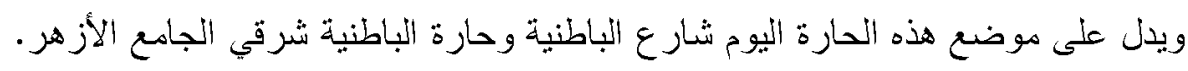

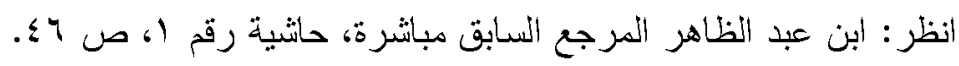

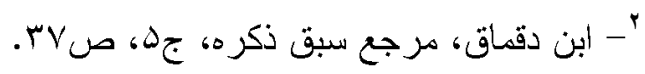

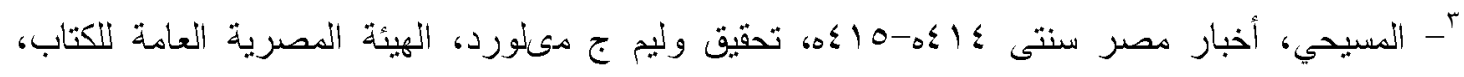

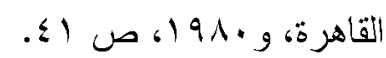

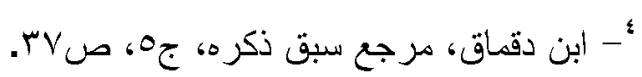

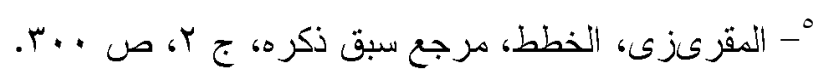

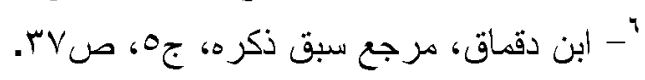

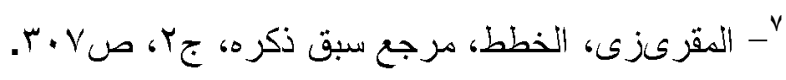

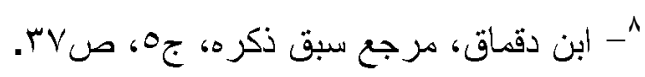

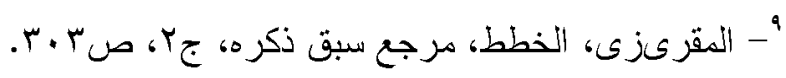




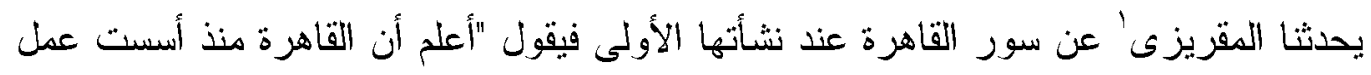

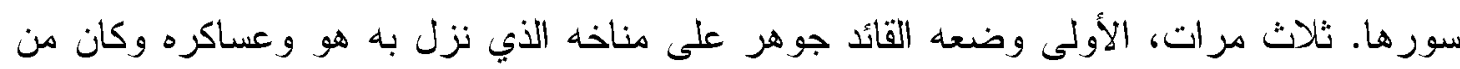

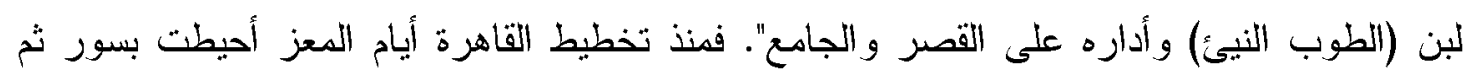

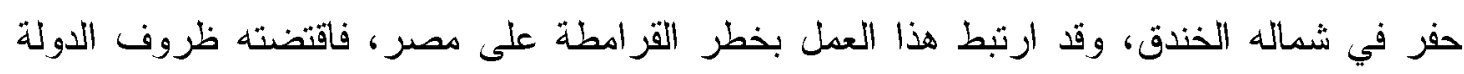

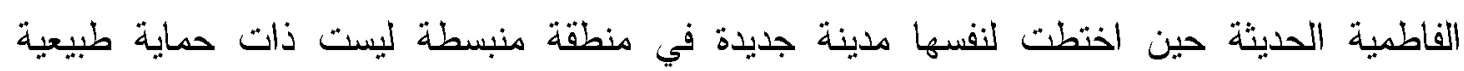

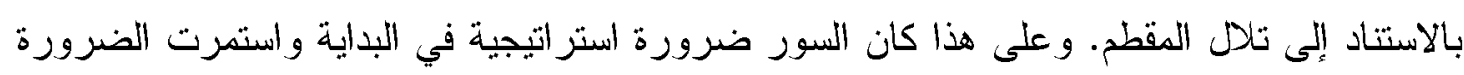

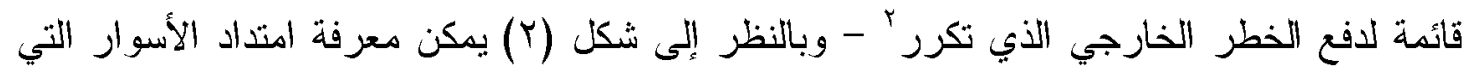

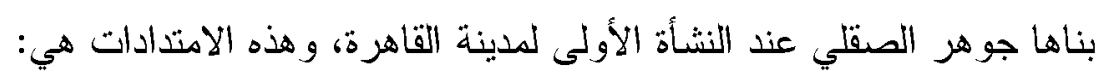
الجهة الجنوبية: ويبدأ من الشرق إلى الغرب بحيث لا لإيكون عموديا على الخليج أي يميل

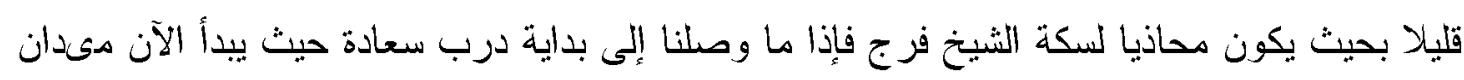

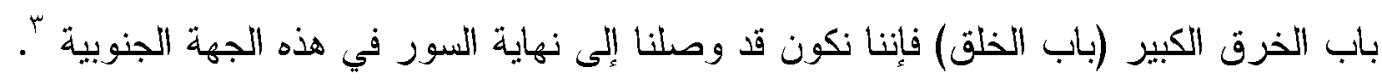

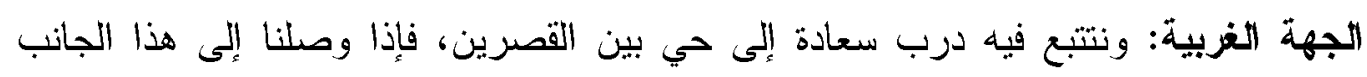

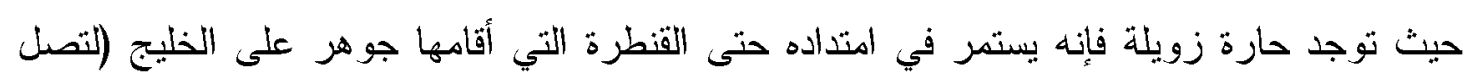

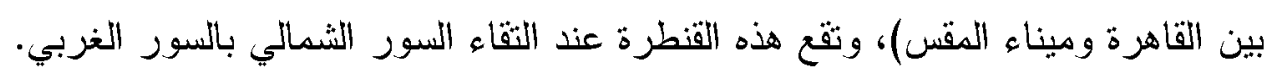

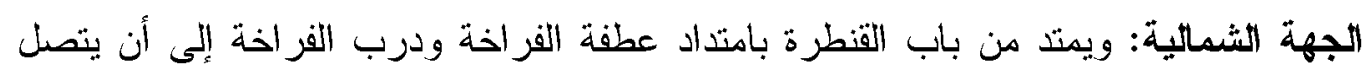

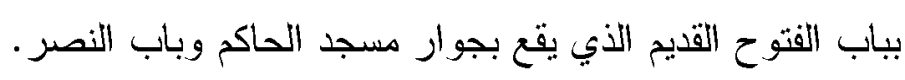

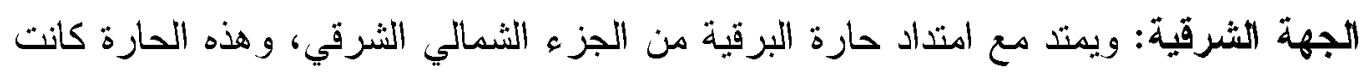

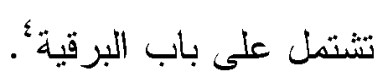

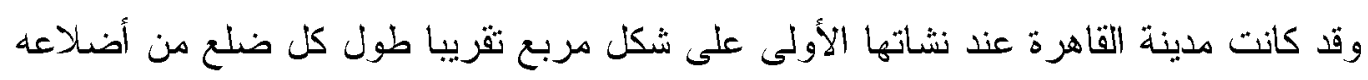

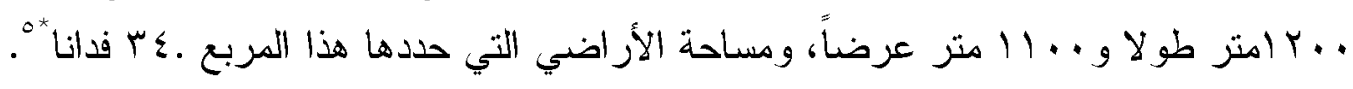

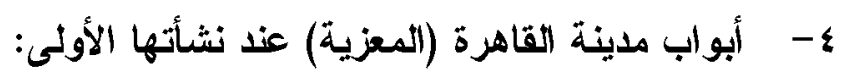

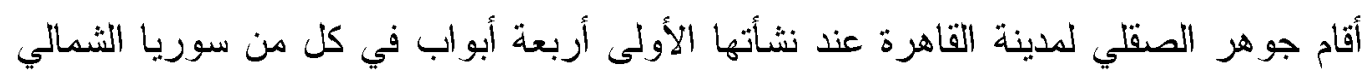

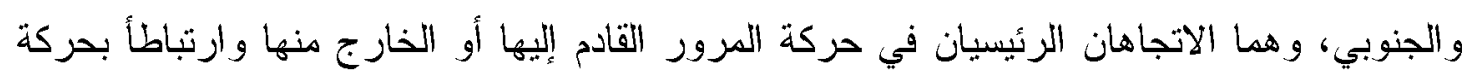

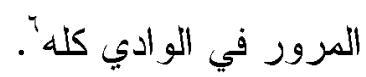

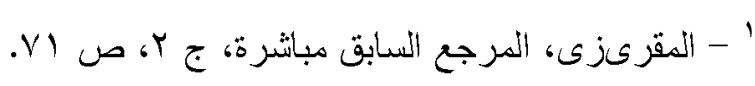

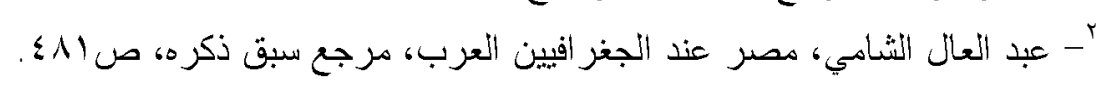

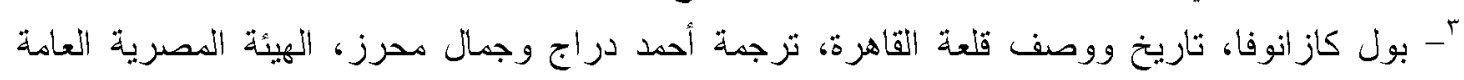

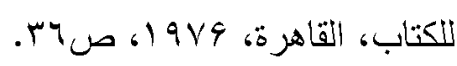

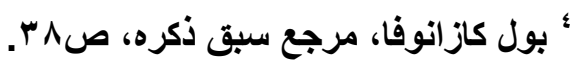

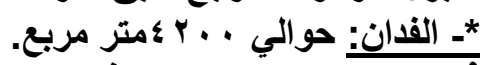

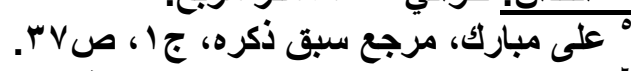

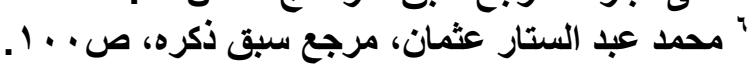


أ. السور الثمالي: يوجد به بابان أحدها باب النصر، يقول عنه ابن عبد الظاهر ' "يخرج منه

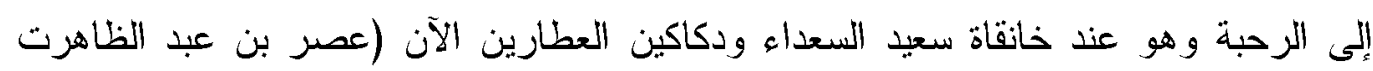

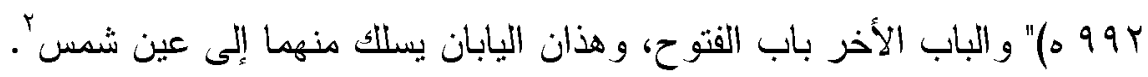

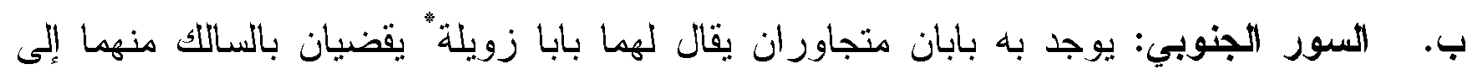

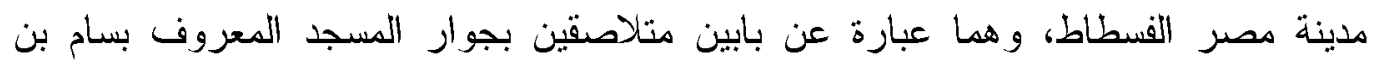

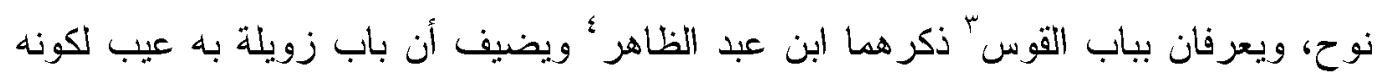

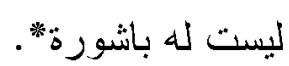

قدامه ولا خلقه على عادة الأبواب " ويضيف ابن عبد الظاهره أن كل هذه الأبواب والسور كانت

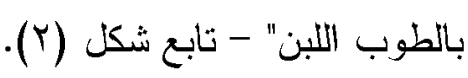

ه- - تركيب مدينة القاهرة (المغزية) عند نثأتها الأولى:

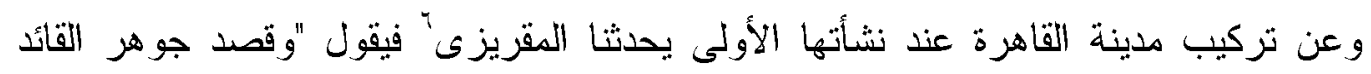

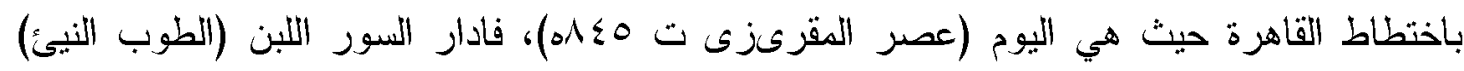

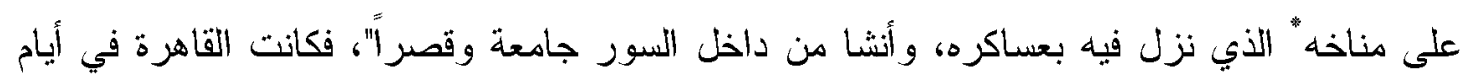

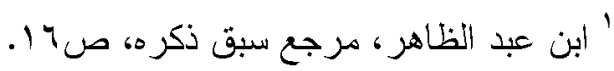

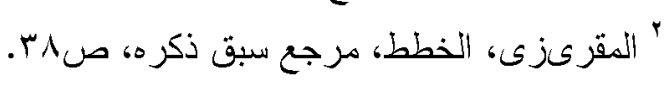

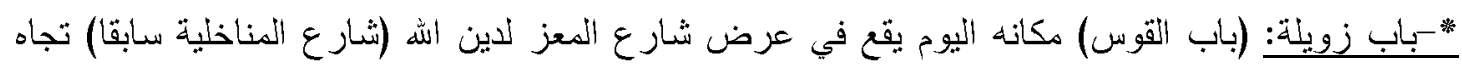

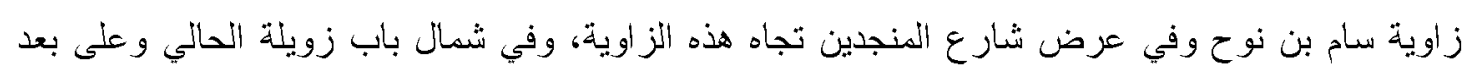

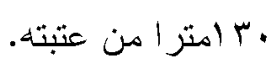

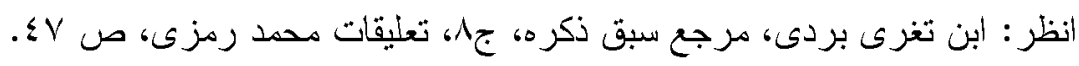

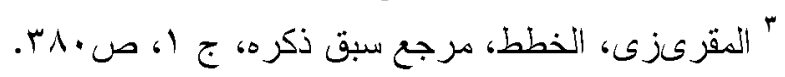

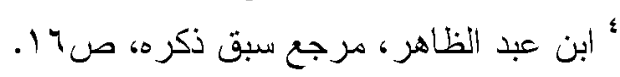

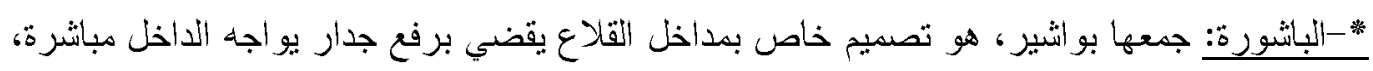

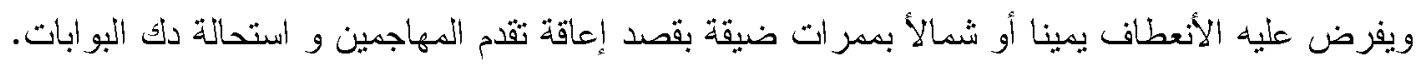

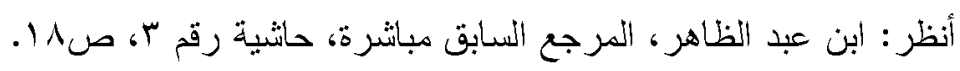

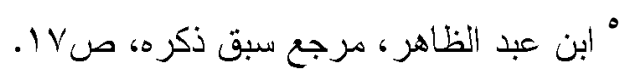

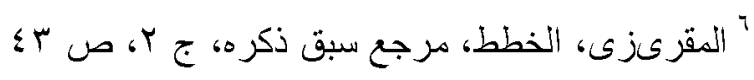

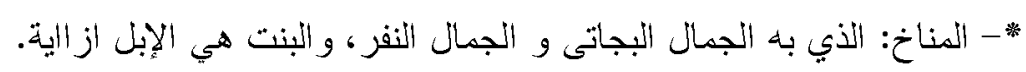

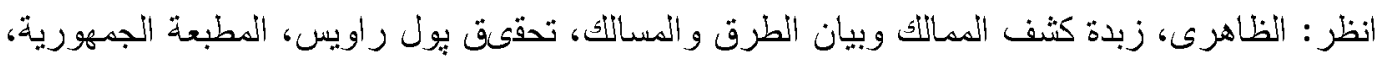

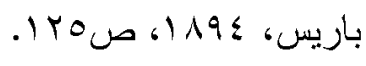


جوهز صغيرة ليس بها سوى قصر الخليفة والجامع الأزهر وثكنات الجنود ودور المغاربة ورجال

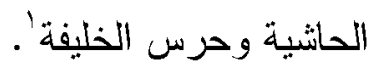

أ- القصر الكبير الثرقي: يقول عنه ابن عبد الظاهر "ولما بني القائد جوهر القصر وحفر أساسه

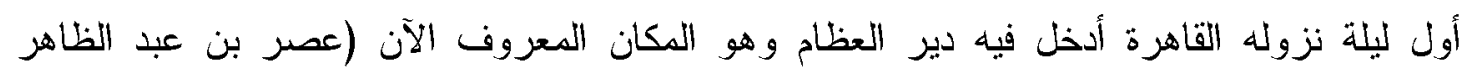

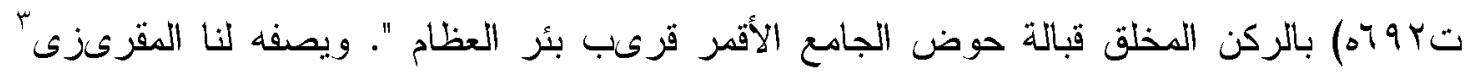

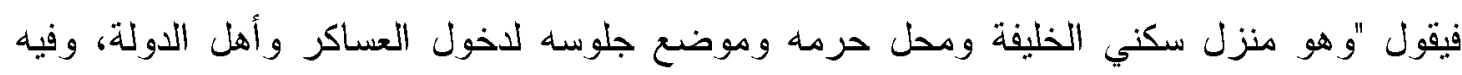

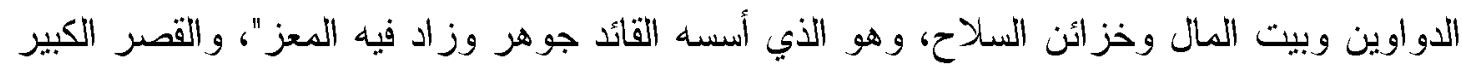

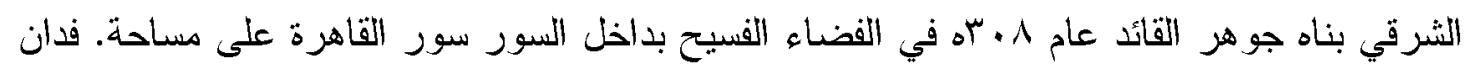

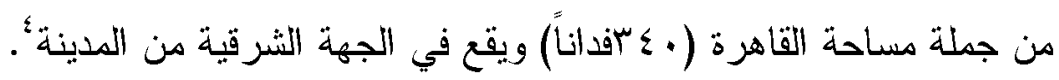

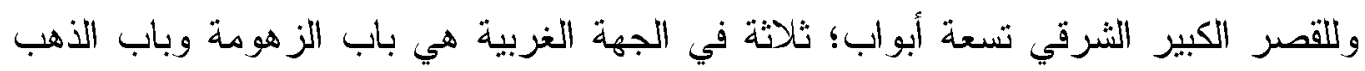

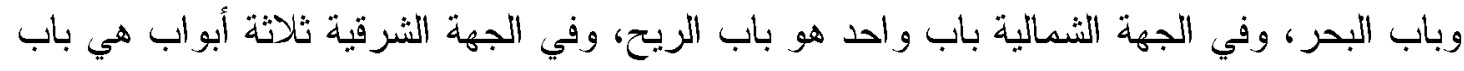

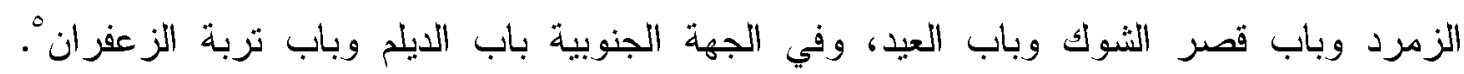

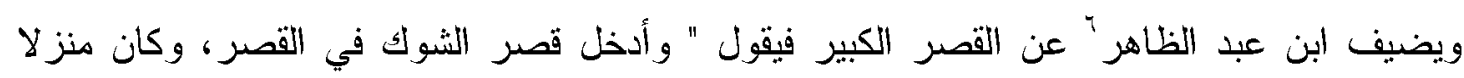

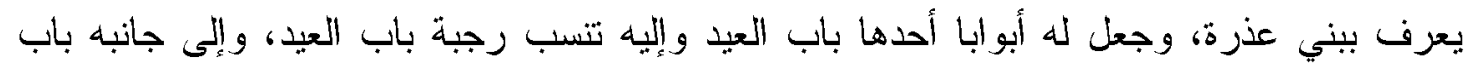

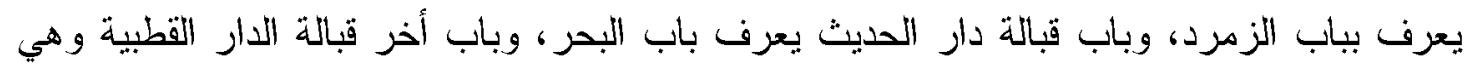

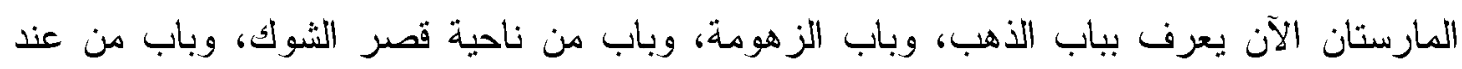

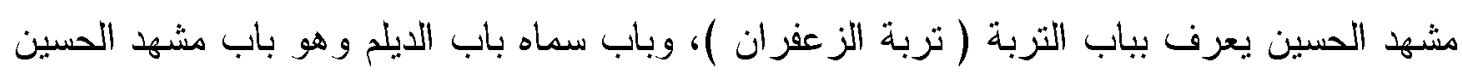

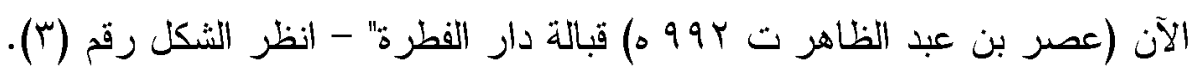

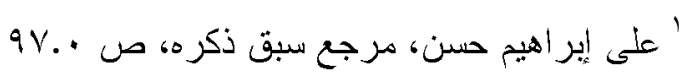

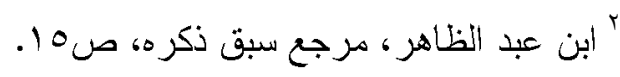

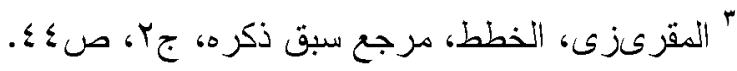

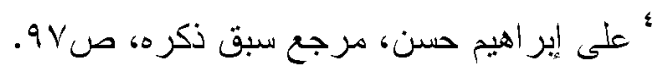

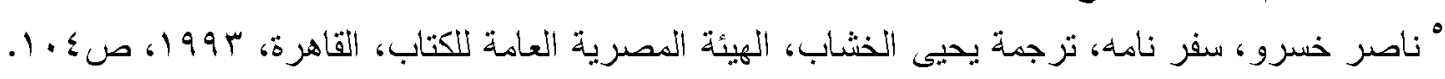

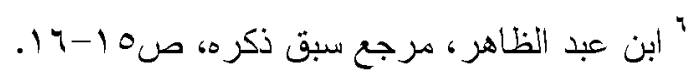




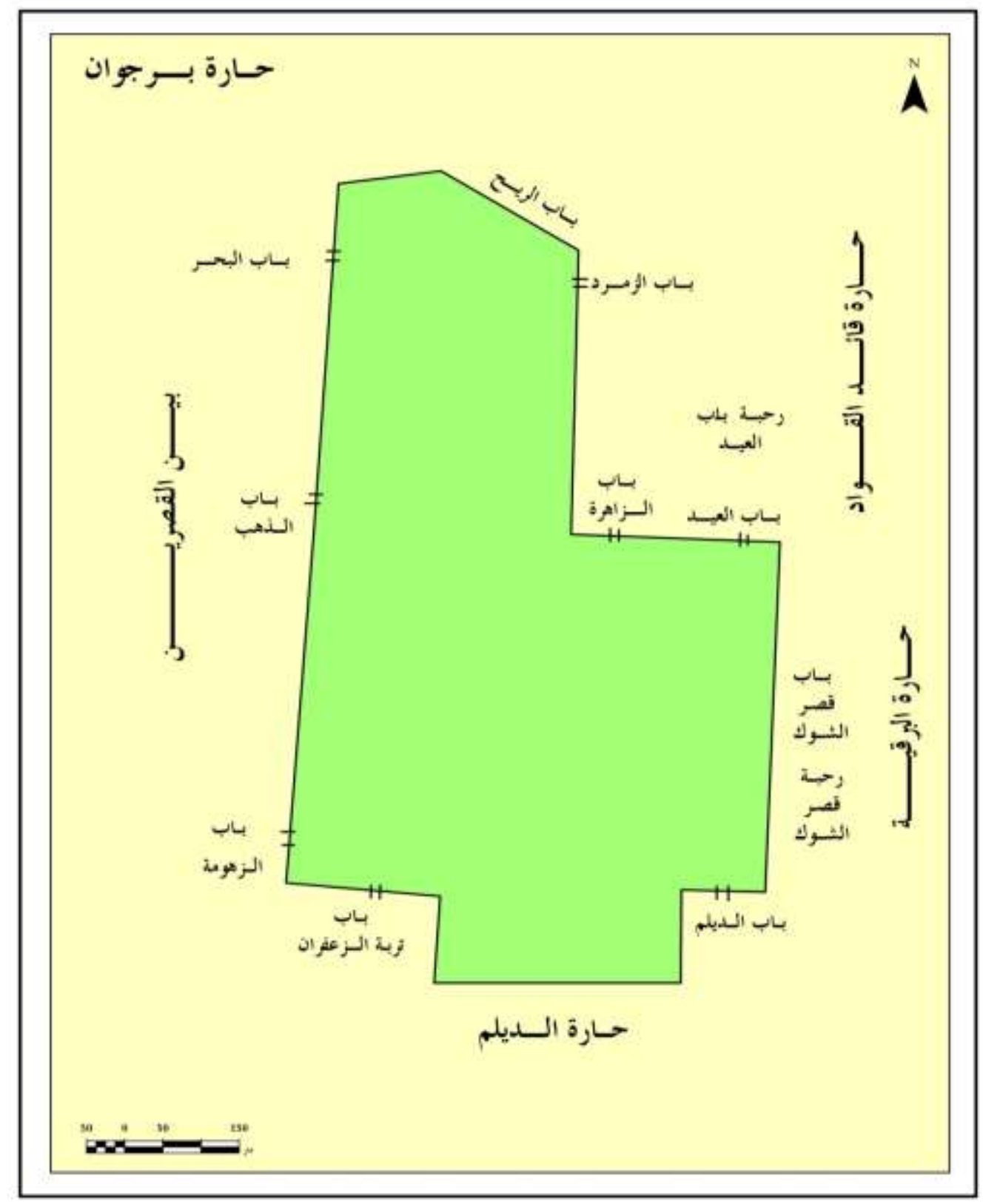

المصدر : أندريه ريمون، القاهـرة تاريخ حاضرة، دار الفكر للار اسات و النشر و التوزيع،ب9919 شكل (r) القصر الكبير المعزي 
"باب الذهب" ذكره المسبحي' في أحداث عام 10ءه فقال "وجلس الظاهر بن الحاكم بأمر الله

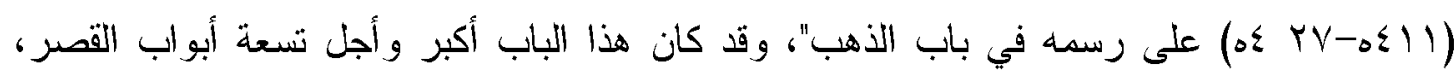

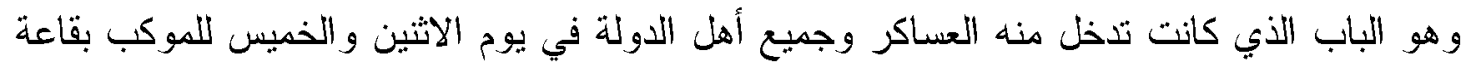

*باب العيد ذكره أيضا المسيحيّ في أحداث عام 0 اعه فقال ودخل الناس إليه من باب العبد"

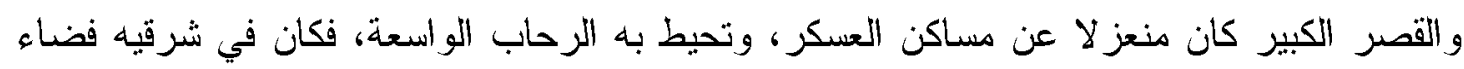

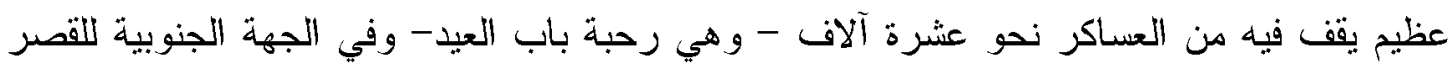

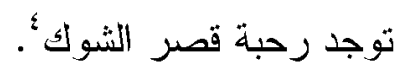
أ. الجامع الأزهر: يقول عنه المقريزى "الجامع الأزهر يقع مقابل باب الديلم (للقصر الكبير

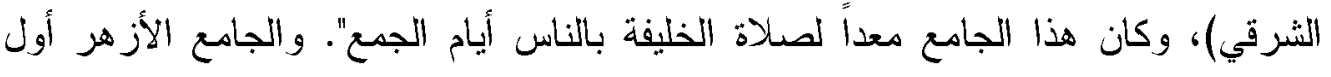

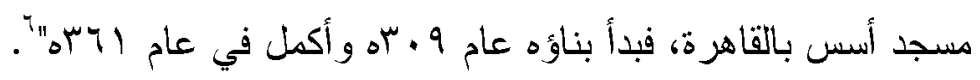

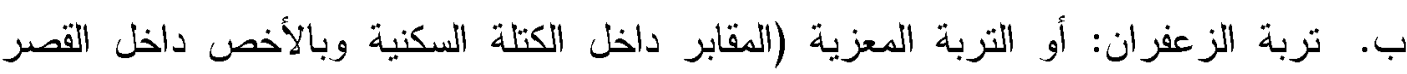

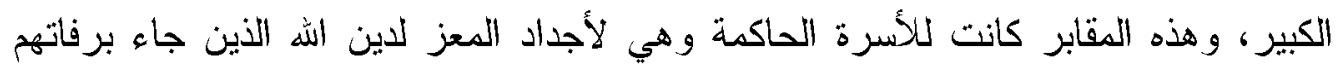

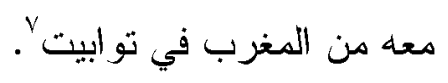

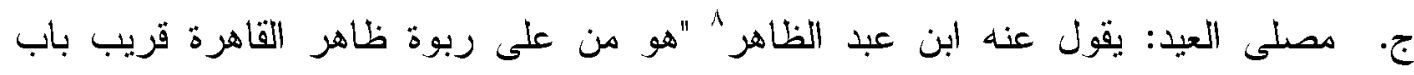

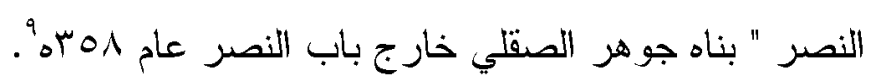

ثأثا: النمو العمراني لمدينة القاهرة في العصر الفاطمي:

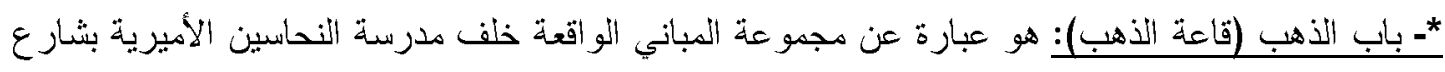

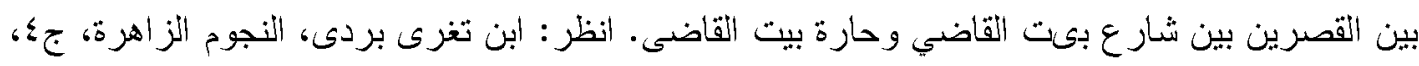

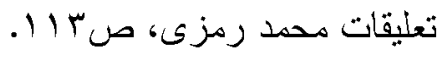

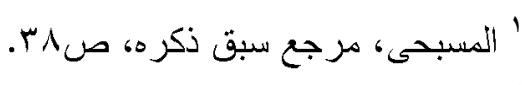

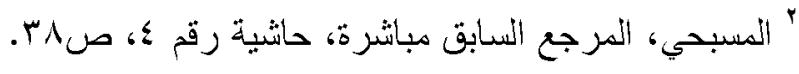

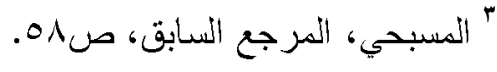

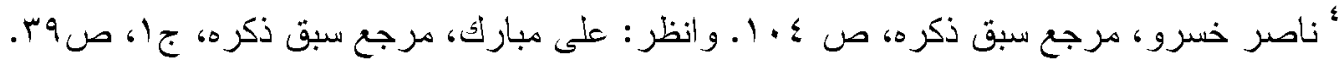

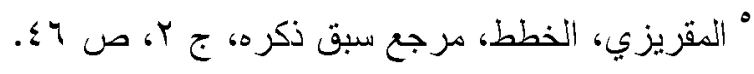

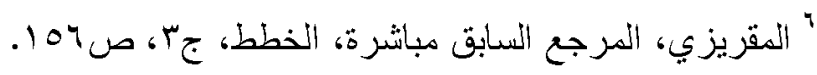

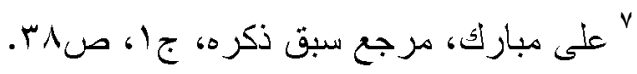

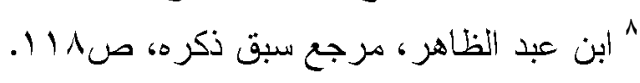

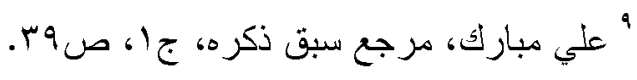


ويتاول هذا الجزء النمو العمر اني الذب حدث لمدينة القاهرة في العصر الفاطمي داخل وخارج

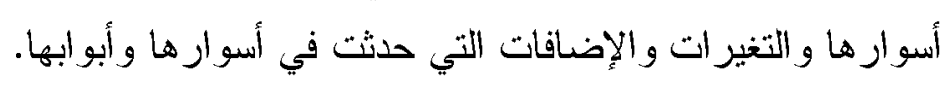

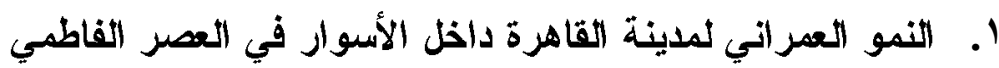

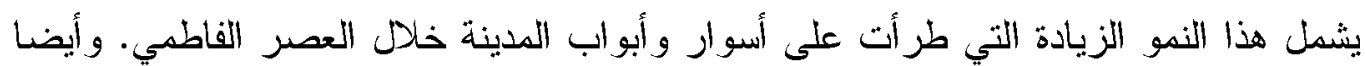

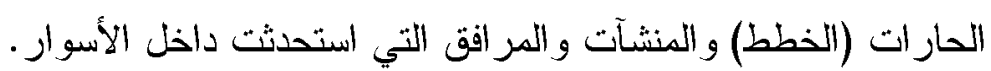

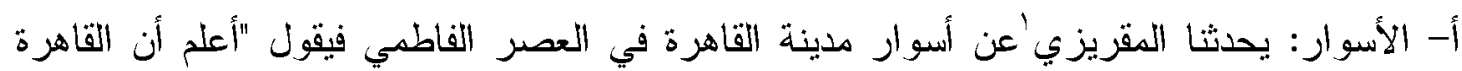

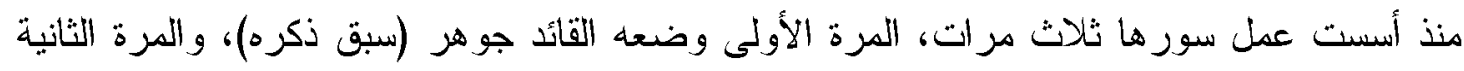

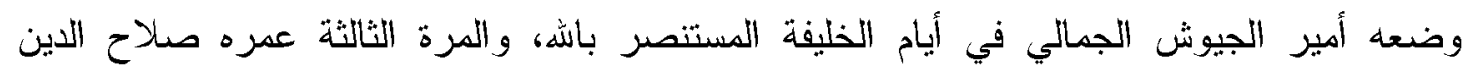

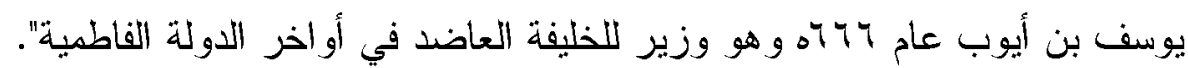

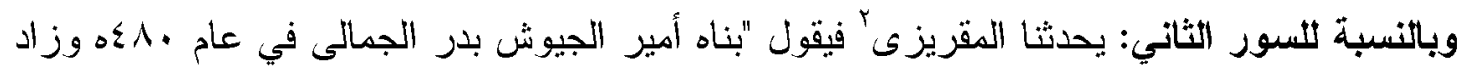

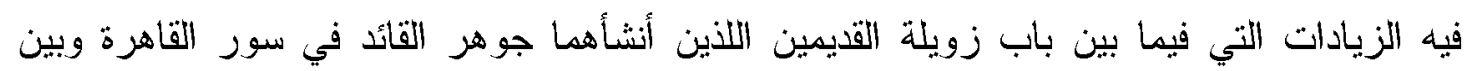

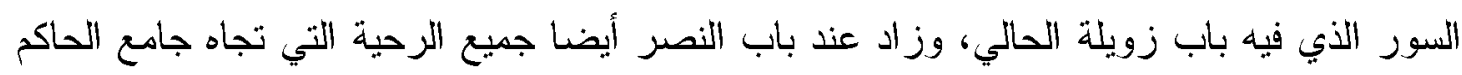

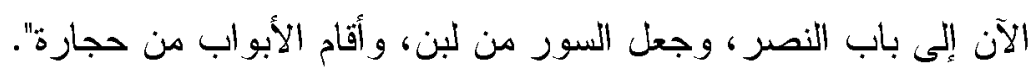
والزيادة التي برز بها بدر الجمالي في الجهة الثمالية من سور جوهر هي التي تحد اليوم من التهن

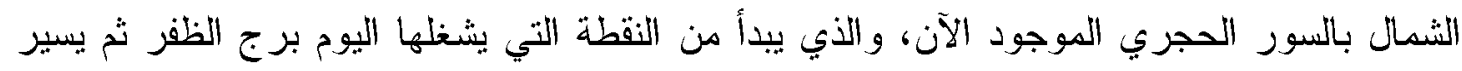

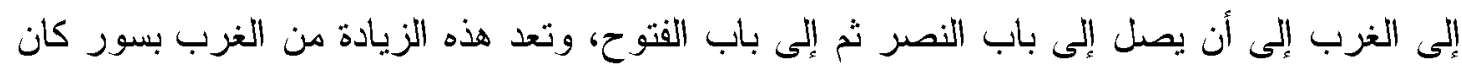

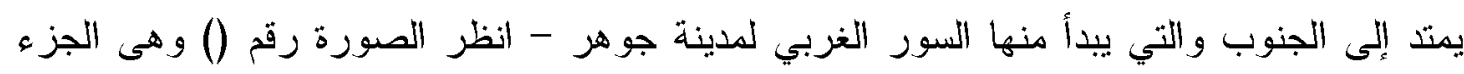
مما تبقى من السور الثمالي.

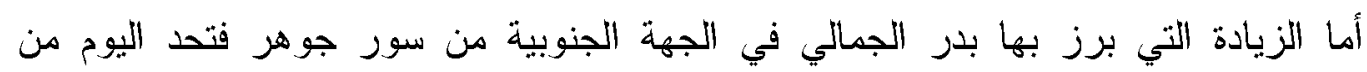

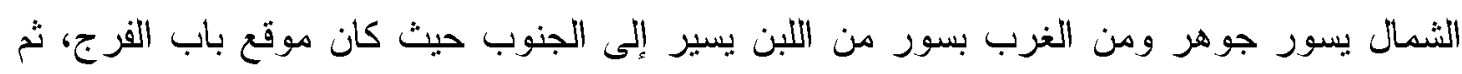

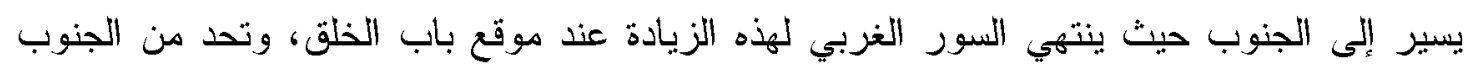

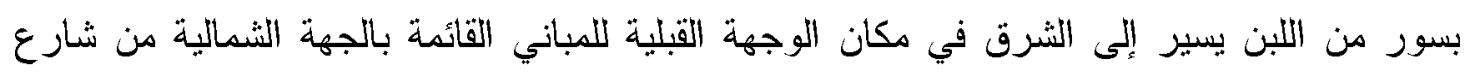

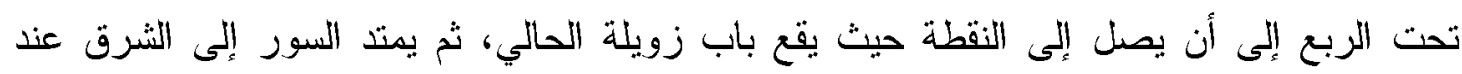

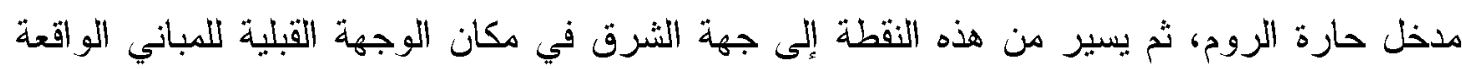

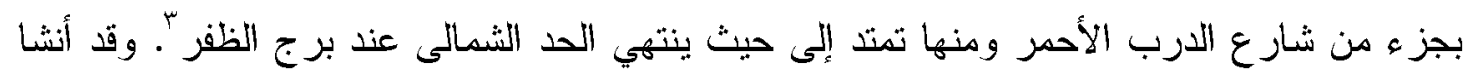

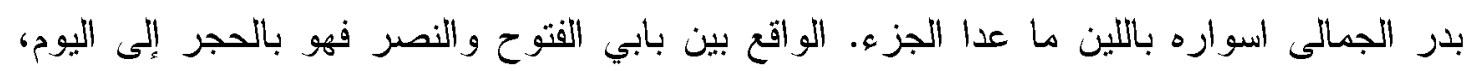

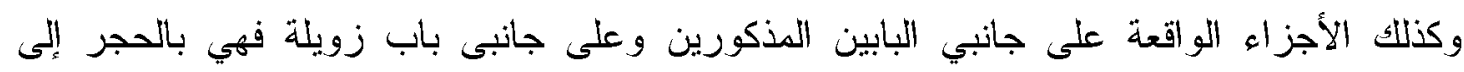

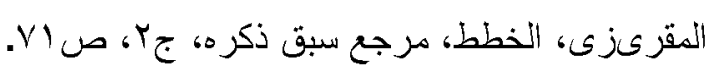

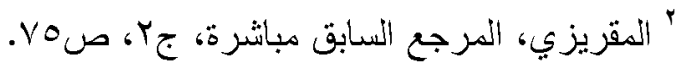

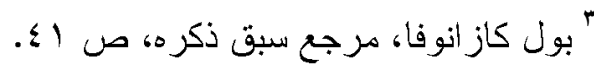


مسافة . ب امترا تقريبا من كل جانب'. وقد زاد السور الذي أقامه بدر الجمالي في مساحة مدينة

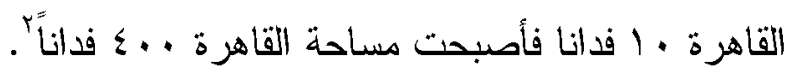
السور الثالث: يقول عنه المقريزيّابتدأ في عمارته السلطان صلاح الدين يوسف بن أيوب في عام

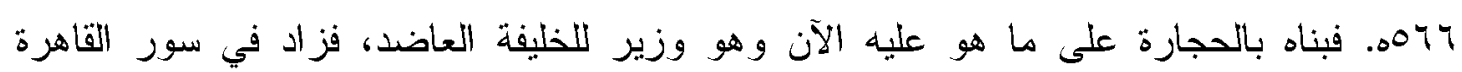

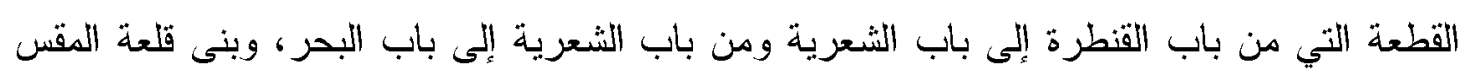

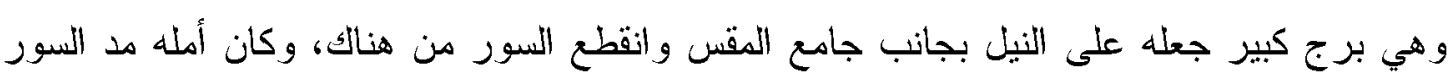
من المقس إلى أن يتصل بسور مصر الفسطاط، وزاد في سور القاهرة قطعة مما يلى باب النصر ممتدة إلى باب البرقية". وبذلك أصبح السور الغربي على الحافة اليمني الخليج المصري في محاذاة سور جوهر القائد

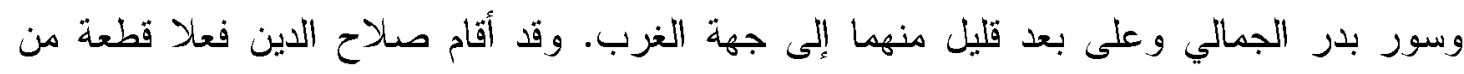
السور الغربي وهى الممتدة من النهاية الغربية لسور بدر الجمالى الثمالي متجهة نحو الجنوب إلى الى

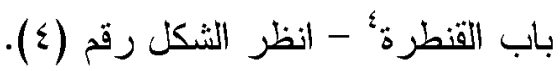

ب- الأبو اب" وما طر أ عليها من تغيرات وما استجد منها خلال العصر الفاطمي، ومن العوامل التي حددت أماكن هذه الأبواب في الأسوار هي ارتباطها بحق الطريق والارتفاق من جهة، وتخطيط هذه

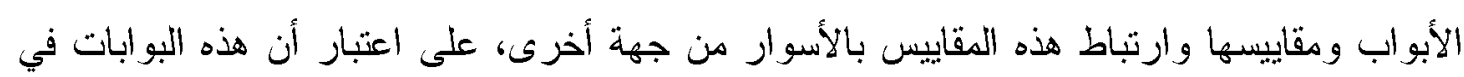
مستوى أعلى من طرق المدينة عن طريق زلاقات حجرية تتحكم في شكل الطريق وحركة المرور فيه. وقد يكون فتح الأبواب في الأسوار لتيسير الاتصال بين المدينة وظو اهر هاء.

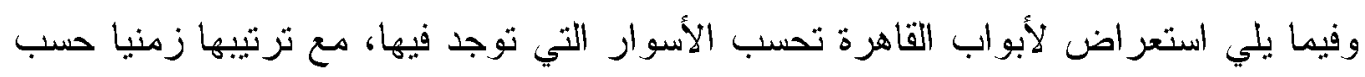
تازيخ إنشائها وتاريخ تجديدها.

$$
\begin{aligned}
& \text { ' عبد الرحمن زكى، مرجع سبق ذكره، صلrr. }
\end{aligned}
$$

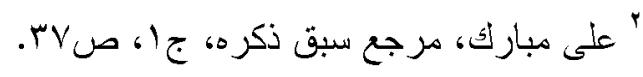

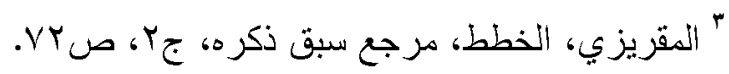

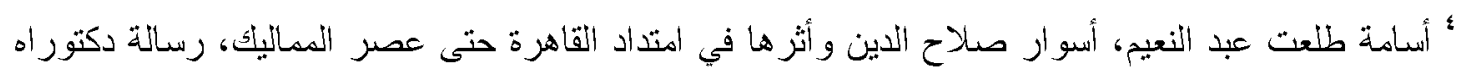

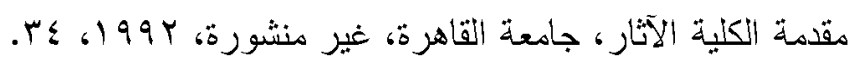

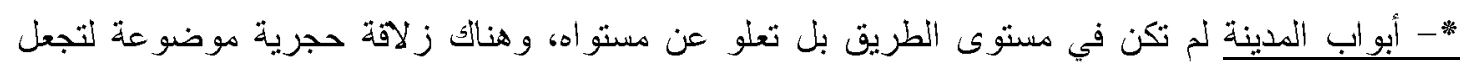

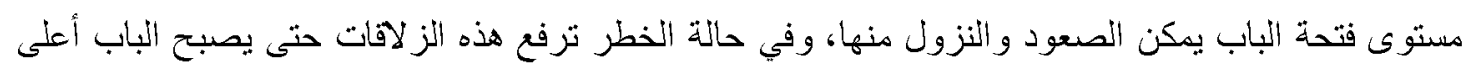

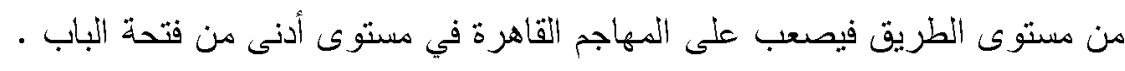

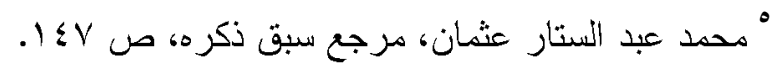




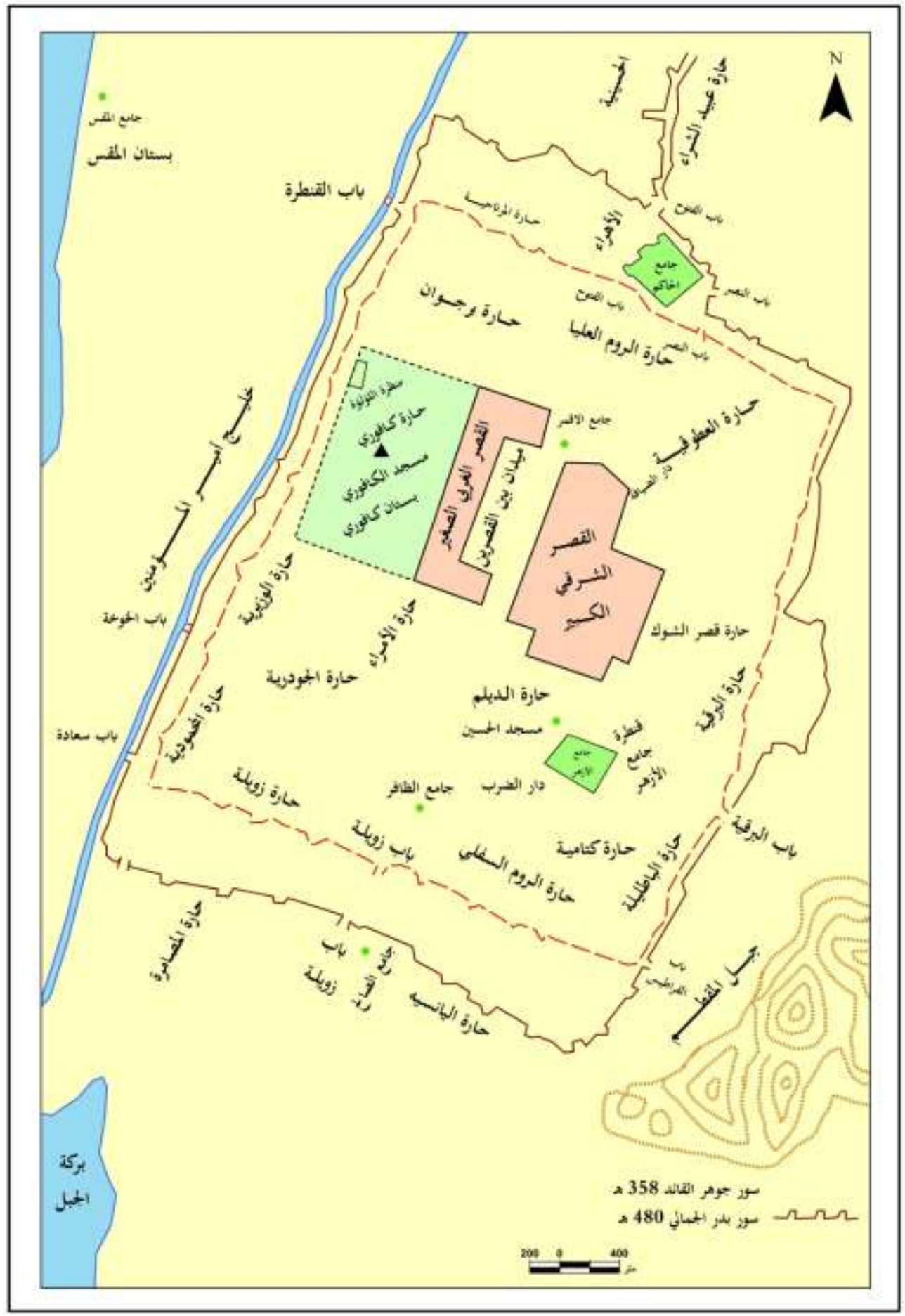

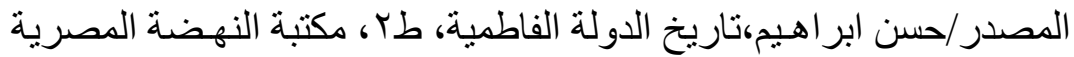

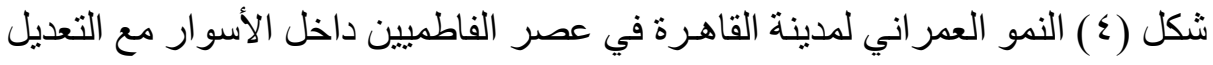




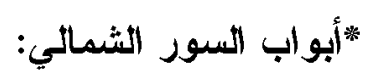

باب النصر: يقول عنه المقرىزى' "باب النصر أولاً دون موضعه اليوم، فلما كان في أيام

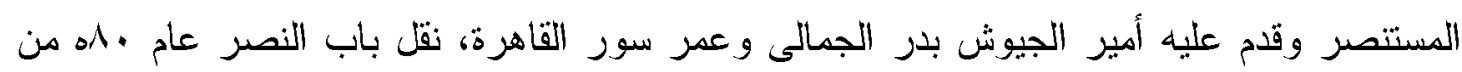

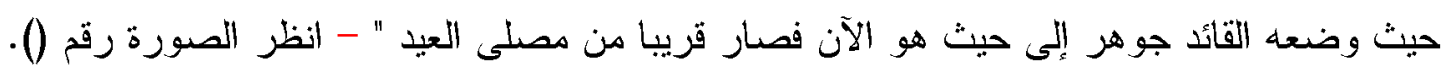

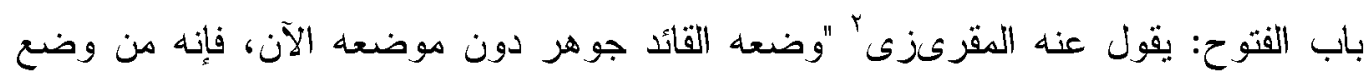

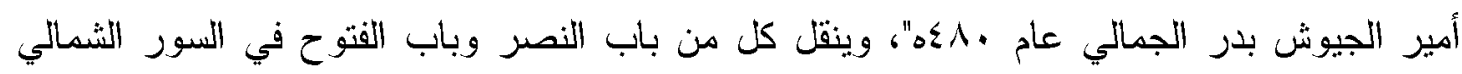

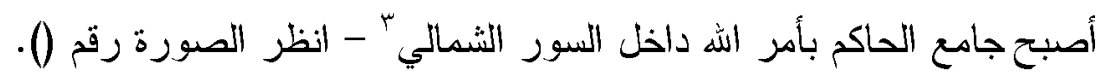

\section{*أبواب السور الغربي:}

باب سعادة:" أنشىُ عام •بسه، وعرف باسم سعادة بن حيان غلام المعز لدين الله وأحد قواده، وهو يقع بالطرف الجنوبي للسور الغربي لمدينة القاهرة'.

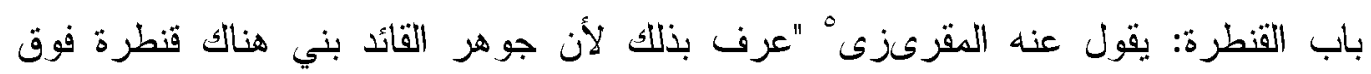

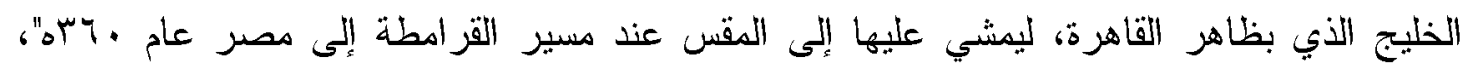

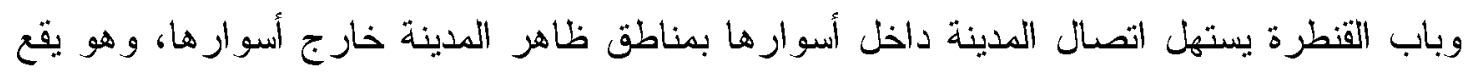
في السور الغربي للمدينة.

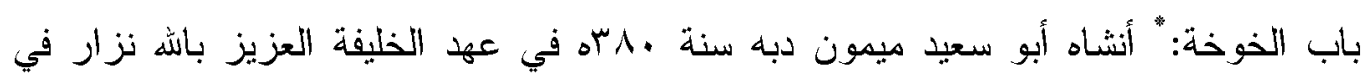
السور الغربي للمدينة' باب.

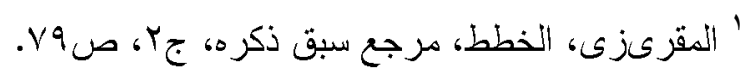

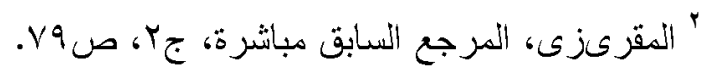

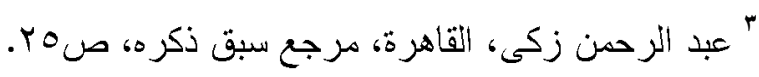

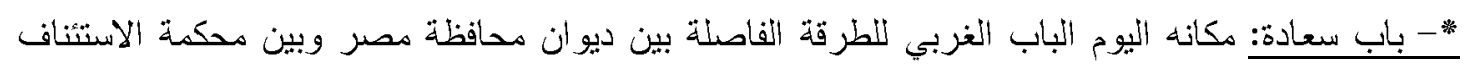
الالهلية بميدان باب الخلق بقسم الأبرب الأحمر بالقاهرة.

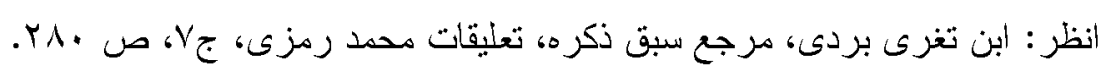

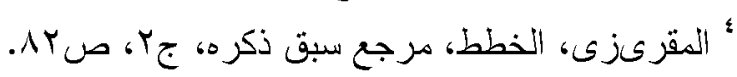

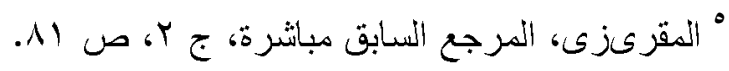

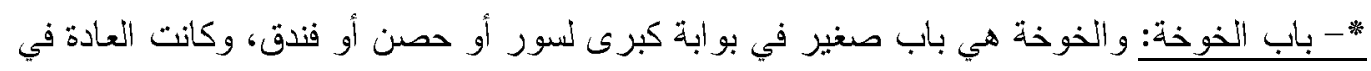

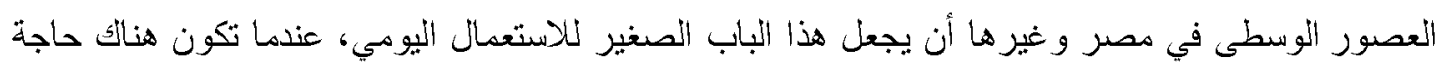

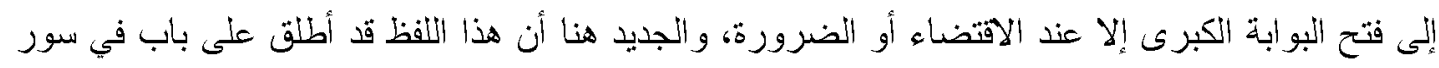

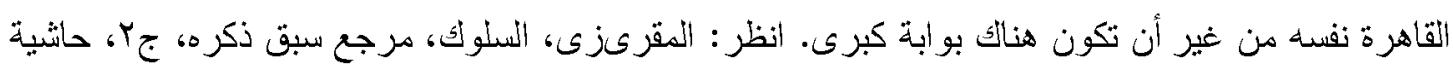

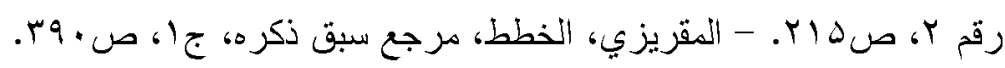

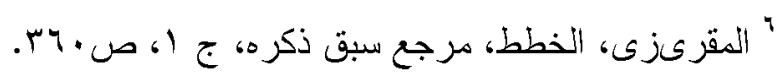




$$
\text { *بواب السور الجنوبي: }
$$

باب زويلة الكبيز : بحدثا عنه المقريزى' فيقول "قلما كان في سنة هیءه بني أمبر الجيوش بدر الجمالي وزير الخليفة المستصر بالله باب زويلة الكبيز الذي هو باق إلى الآن"، ويقع باب زويلة

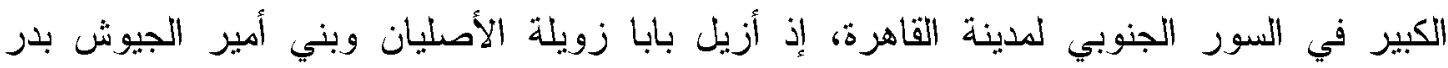

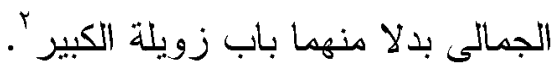
باب الفرج:" وهو يقع في النقطة عند التقاء السور الغربي والجنوبى بـ (ولم تذكر المصادر التاريخية تاريخ إنشائه).

$$
\text { *أبواب السور الثرقي: }
$$

باب القراطين (المحروق): عرف بهذا الاسم لأنه كان يقع بجوار سوق المواشي و الغنم وكان يجلس عنده القز اطون الذين يبيعون القرط (البرسيم) ويقع هذا الباب في السور الثرقي للمدينة؛ باب البرقية: هو أجد أبواب القاهرة في سورها الثرقي، ويقع إلى الثمال من باب القراطين، وينسب إلى جنود برقة. (وهذان البابان لم تذكر المصادر التاريخية تاريخ إنشائهما) - تابع شكل(ع)

أ-حارات (خطط) مدينة القاهرة في العصر الفاطمي: حار ات مدينة القاهزة داخل الأسوار : وهذه الحارات استجدت بعد النشأة الأولى لمدينة القاهرة، منها ع حار ات تتنمي إلى طو ائف عسكر الدولة الفاطمية، وهذه الحار ات هي:

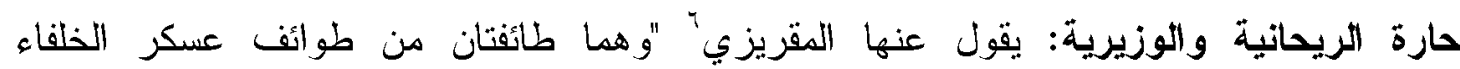
الفاطميين، وبها كانت مساكنهم، وكان فيها لهاتين الطائفتن دور عظيمة وحو انيت عديدة، واتصلت العمارة إلى السور، وكانت خارج باب الفتوح الذبي قطعه القائد جوهر، ثم صارت داخل باب الفتوح

$$
\begin{aligned}
& \text { ' المقرىزى، الخطط، مرجع سبق ذكره، جب، صلVV. }
\end{aligned}
$$

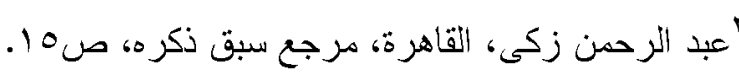

*- باب الفرج: بمكن تحديد موقعه من حارة الجداوى من ناحية السكرية الجامع المؤيد وحمام المؤيد فانثاء

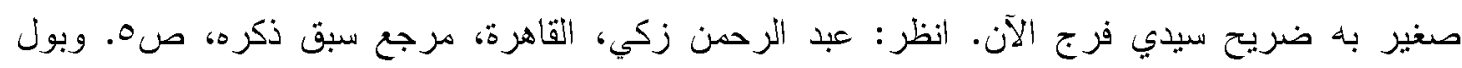

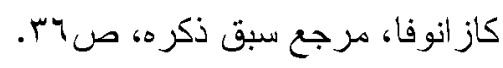

*"- وقد اختلفت المصادر التاريخية في تحديد موقع هذا الباب بالنسبة لأسوار القاهرة.

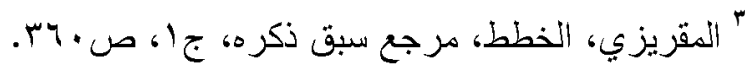

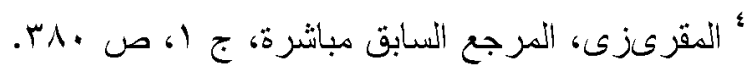

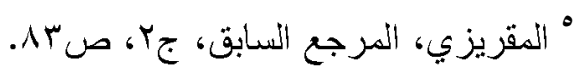

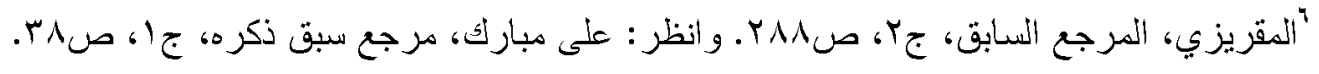


الأي وضعه أمير الجيوش بدر الجمالي". (تغير اسمها في العصر الأيوبي إلى حارة بهاء الدين عام . $007 \mathrm{~V}$ الحارة المحمودية: تقع على بسار الداخل من باب زويلة' يقول عنها المقرىزى " "عرفت بطائفة من

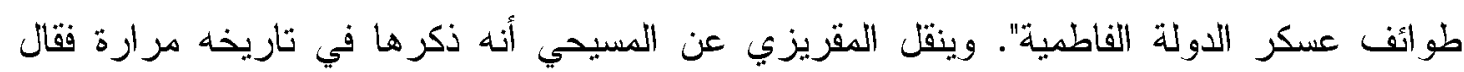
عنها في أحداث عام ؟9ه "اقتتلت الطائفة المحمودية و اليانسية".

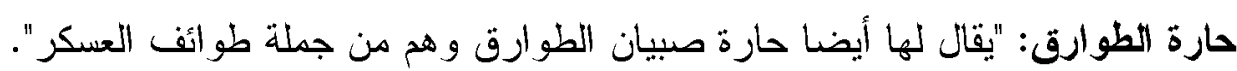

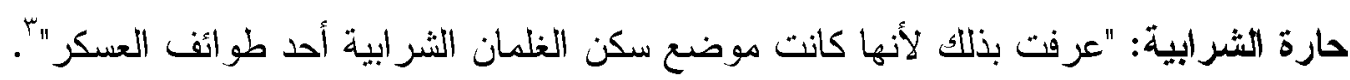

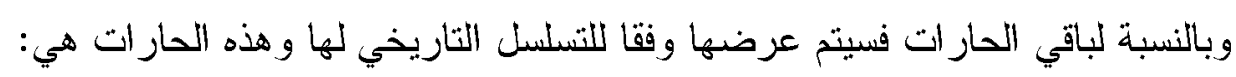

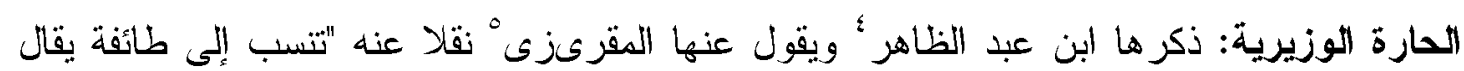

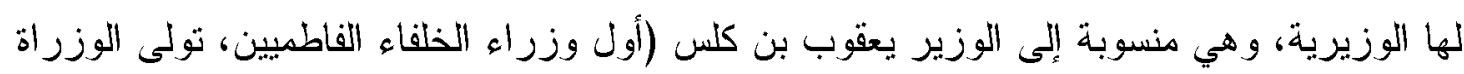

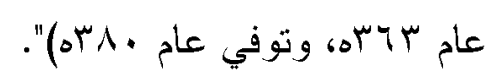

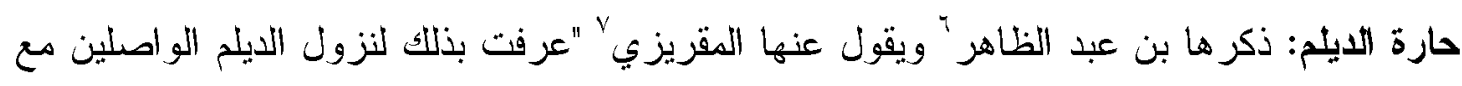

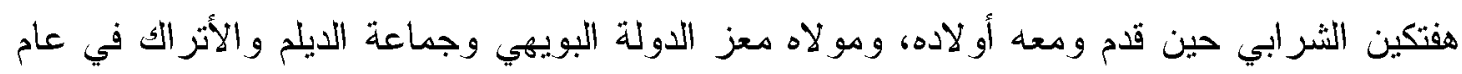

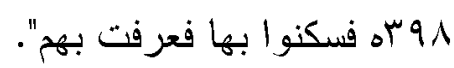
حارة الأتراك: يقول عنها المقريزى ^ "عرفت بهذا الاسم بسبب نزول الأراك مع هفتكين بها أيام

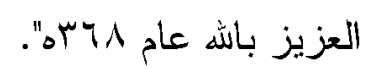

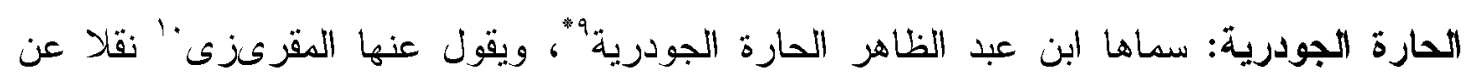

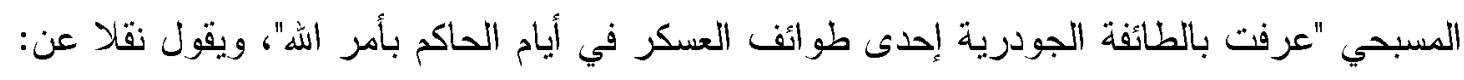

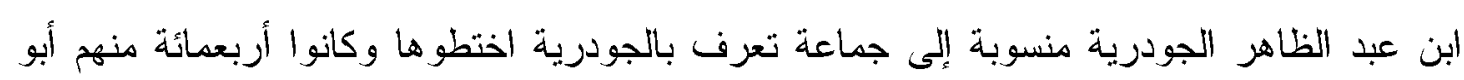

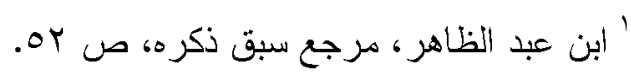

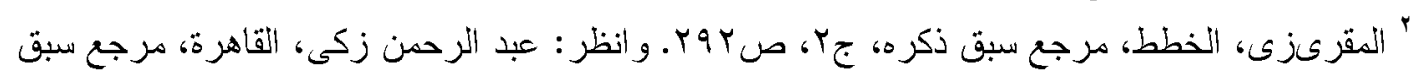

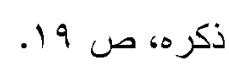

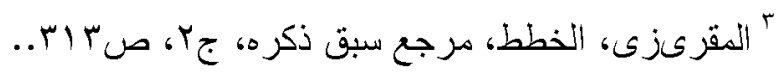

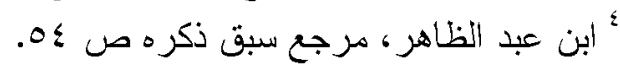

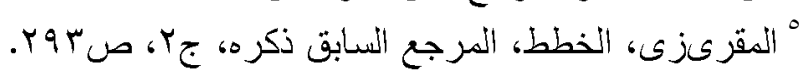

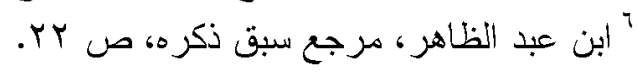

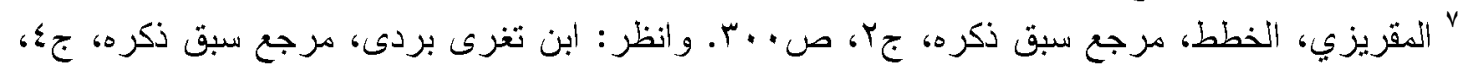

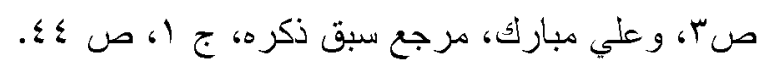

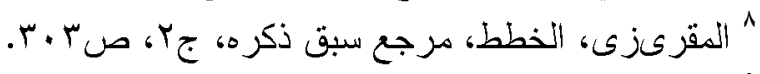

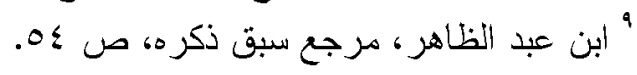

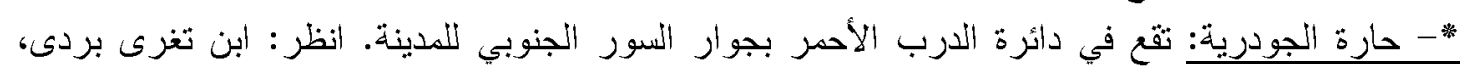

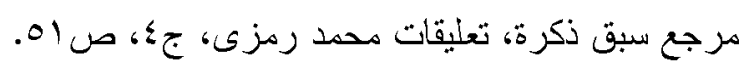

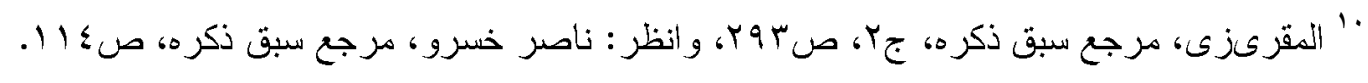


على منصور الجودري الصقلي ت تحشه، وكانو ا في أيام العزيز بالله، وكانت سكنا لليهود فبلغ الخليفة

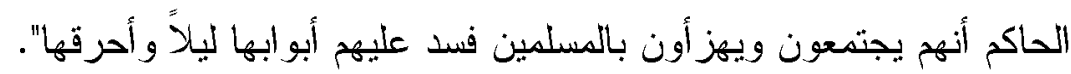

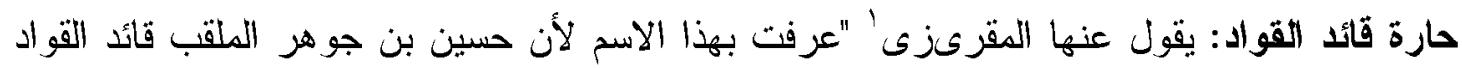

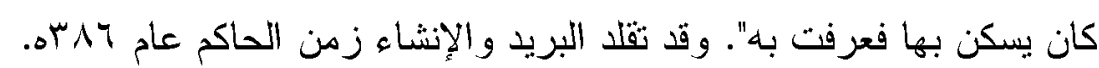

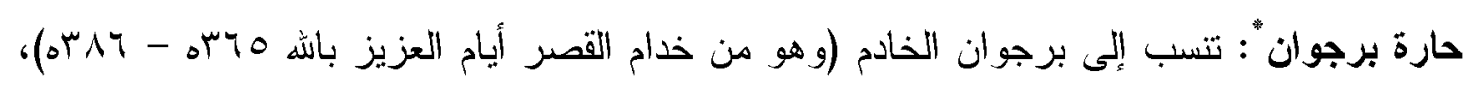

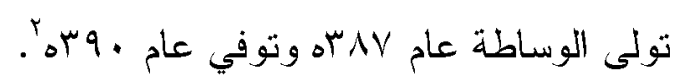

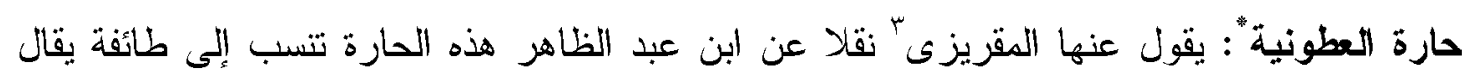

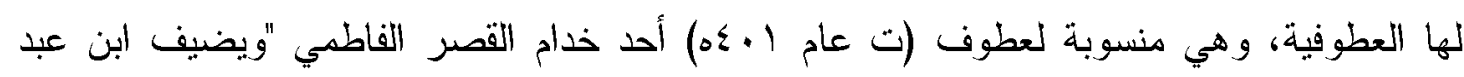

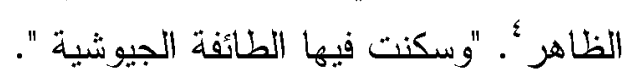
حارة المرتاحية" : "هذه الحارة عرفت بالطائفة المرتاحية". حارة الفرعية: وهي سكن الطائفة الفرحية بجوار حارة المرتاحية (وهي تقع فيما بين سويقة أمير الطير

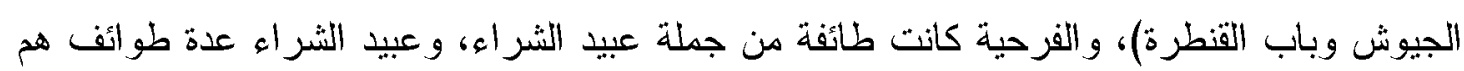

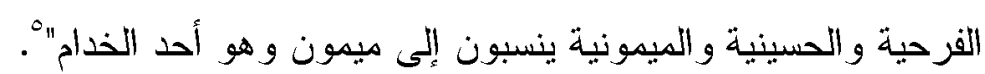

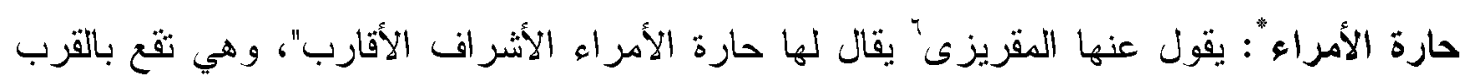

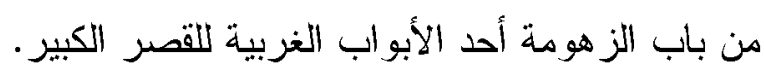

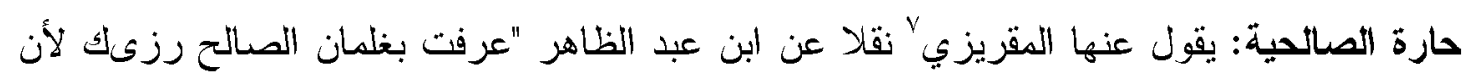
غلمانه يسكنون بها"، وهي تقع بين المشهد الحسيني ورحبة الأيدمري وبين الحارة البرقية.

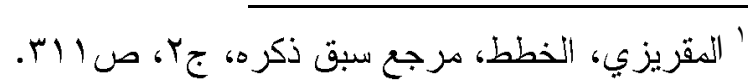

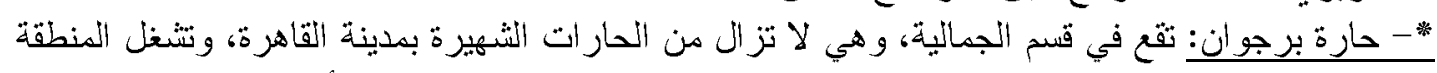

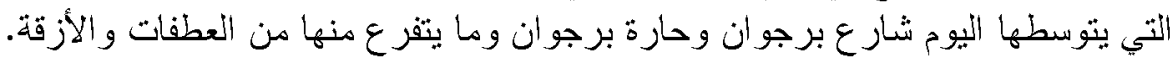

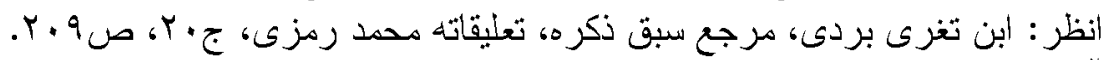

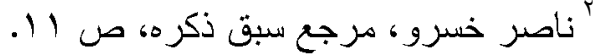

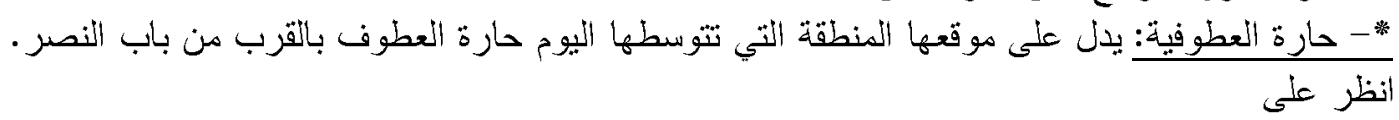

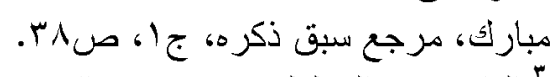

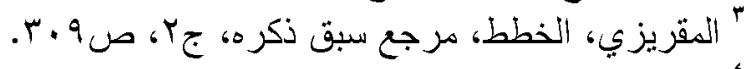

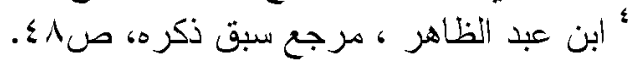

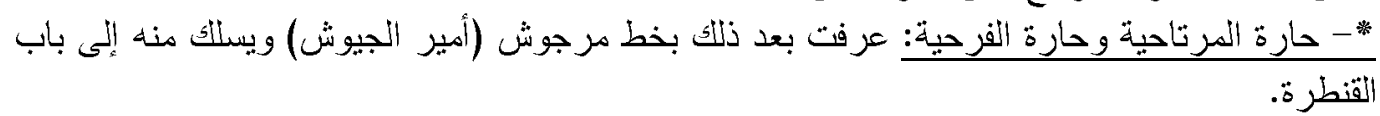

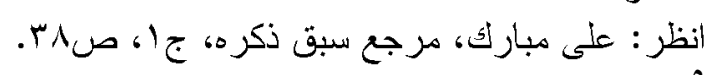

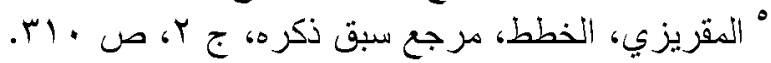

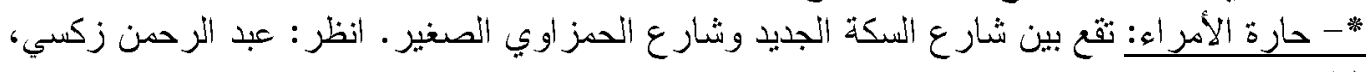

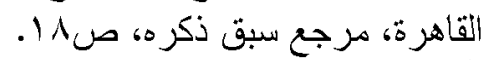

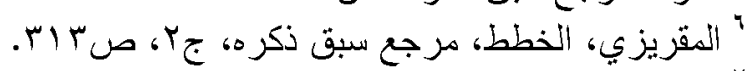

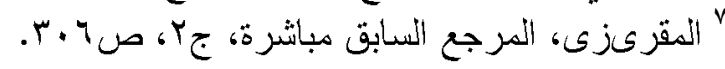


حارة الكافورى: كانت بستانا لكافور الإخشيدي ثم صارت من بعده للخلفاء الفاطميين حتى أصبحت حارة للسكني' حارة قصر الثوكك" وتتسب إلى القصر الذي يعرف بنفس الاسم في تلك الجهة شرق القصر الكبير

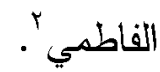

حارات مدينة القاهرة خارج الأسوار: حار ات خار ج باب زويلة: اينة الحارة اليانسية: يقول عنها المقرىزى" نقلا عن ابن عبد الظاهر "تعرف بطائفة من طوائف العسكر

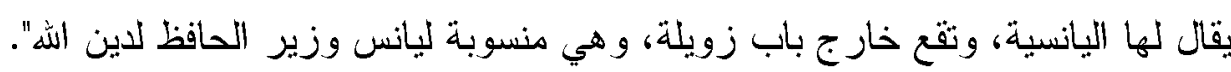

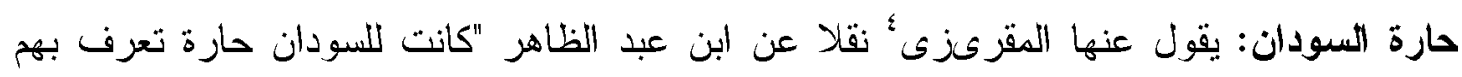

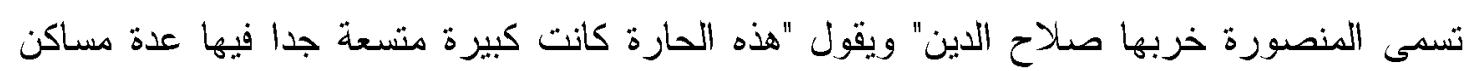
لللسودان و هي خارج باب زويلة". حارة حلب: يقول عنها المقريزى "نقلا عن ياقوت "هي محلة بظاهر القاهزة بالثنارع من جهة

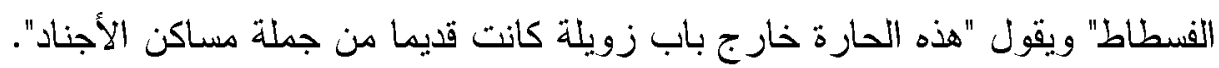

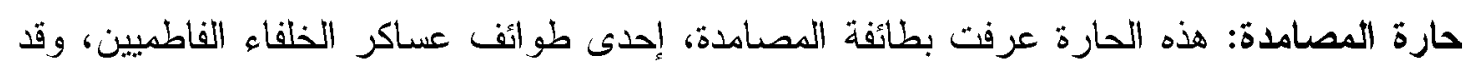

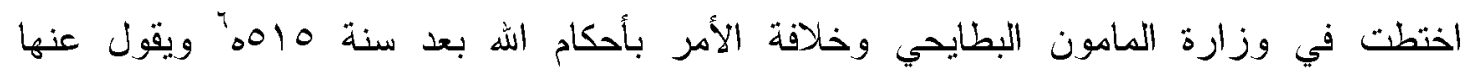

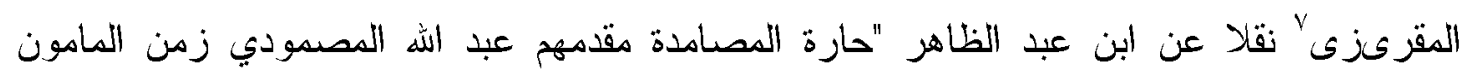

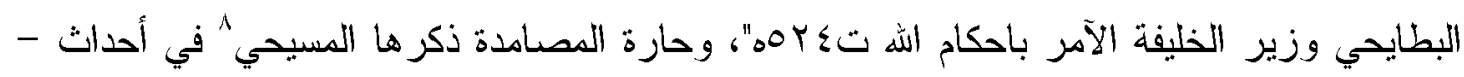
عام 1 اهله فقال "عن و اجبات الدصامدة".

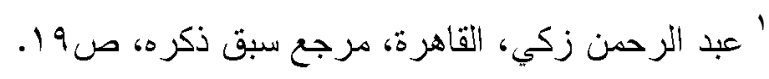

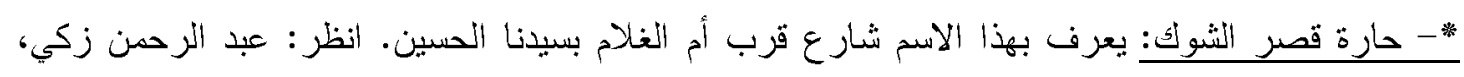

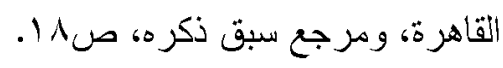

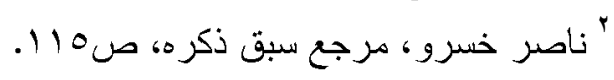

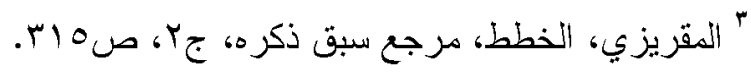

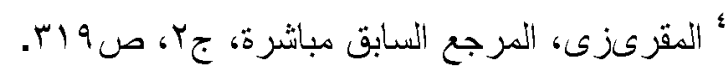

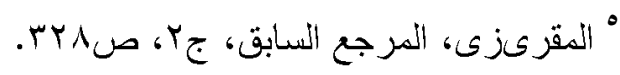

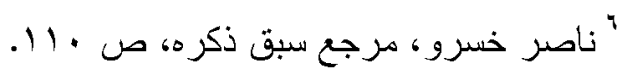

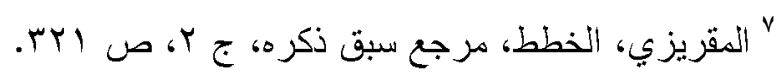

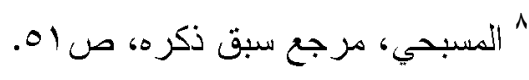




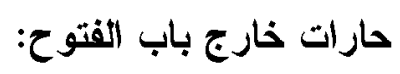

حارة الحسينية: يقول عنها المقرىزى' نقلا عن المسيحي "عرفت بطائفة من عبيد الثراء يقال له

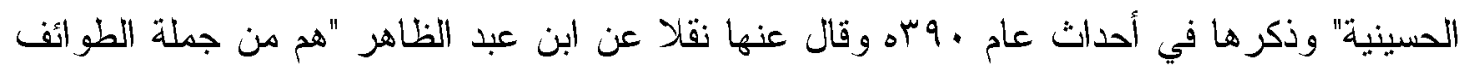

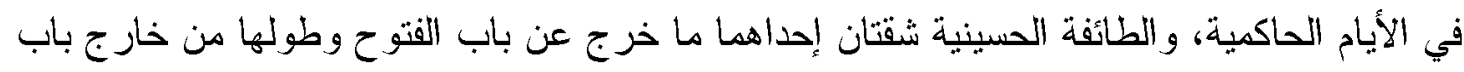

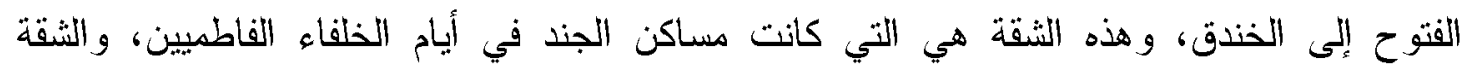

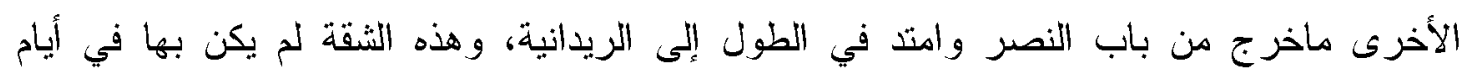

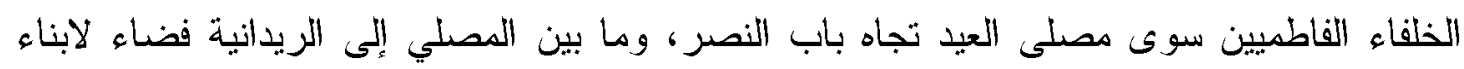

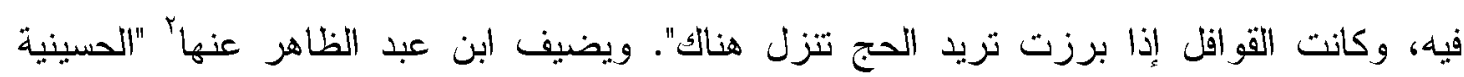

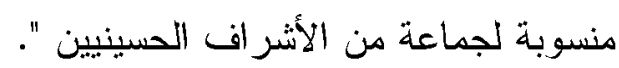

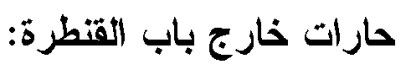
حارة البيازرة: يقول عنها المقريزى" ثقع على شاطئ الخليج من شرقيه، وقد اختطت هذه الحارة في

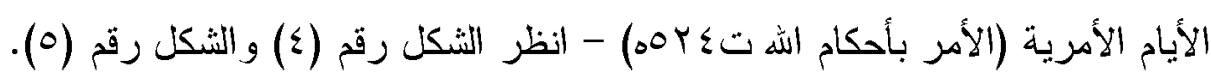

أ- أهم المنثآت والمرافق في مدينة القاهرة في التصر الفاطمي داخل الأسوار:

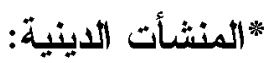
الجو امع:

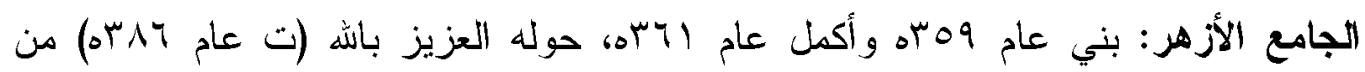
مسجد تقام فيه الثعائر الدينية إلى معهد الثيعة تدرس فيه العلوم، ويروج فيه للهذهب الفاطئ

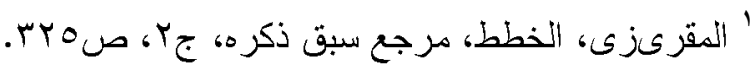

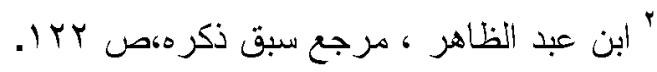

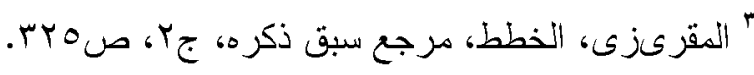

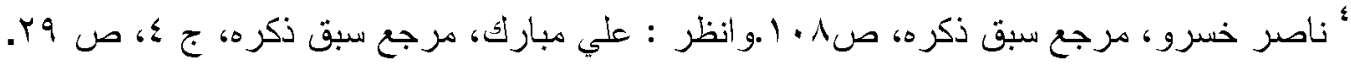




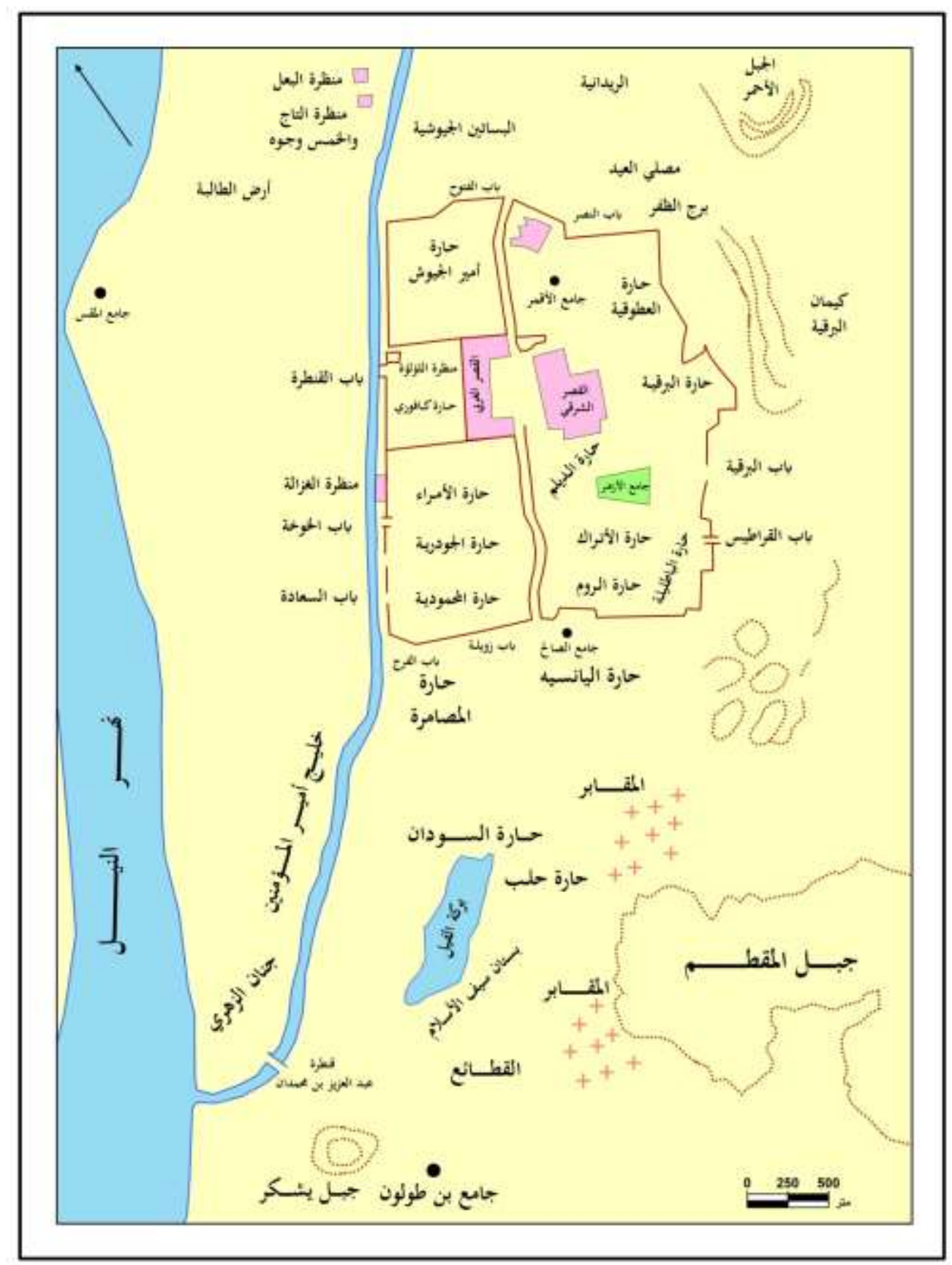

المصدر / عبدالرحمن زكي، مرجع سبق ذكرهـ، ص ҮrT؟.

شكل (0) ملامح النمو العمراني لمدينة القاهــرة خارج الأسوار في العصر الفاطمي 
جامع الحاكم: يقول ابن عبد الظاهر ' " بناه الحاكم بأمر الله وتم بناؤه عام بـوبه، وكان خارج

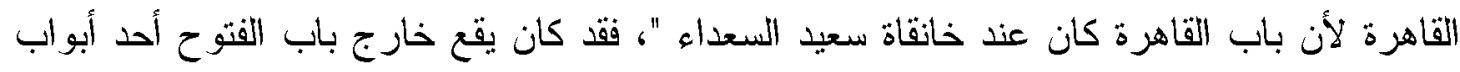

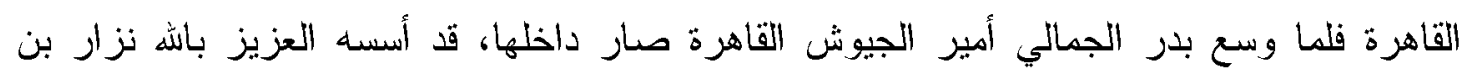

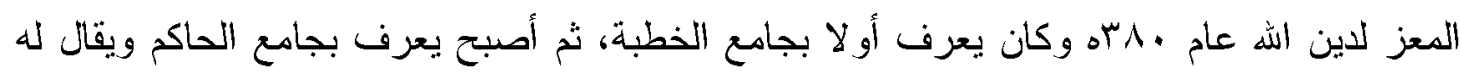

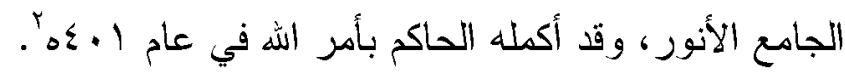

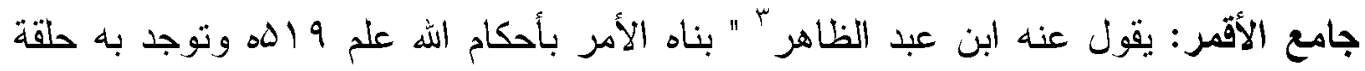

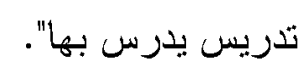
جامع الظافر" (الأفخر): يقول عنه ابن عبد الظاهر " "هو جامع الفكهانيين بناه الظافر وكان

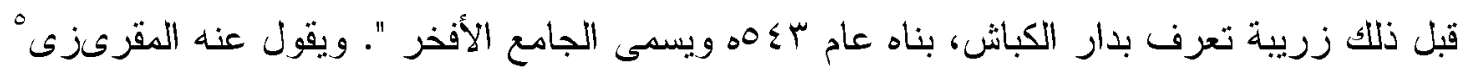

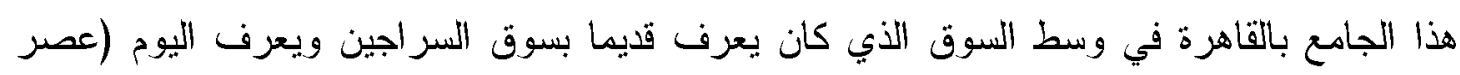

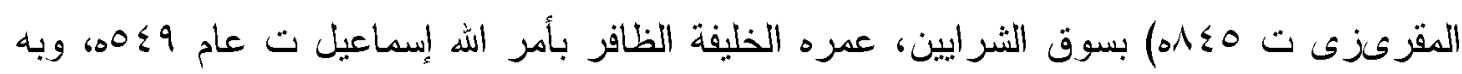

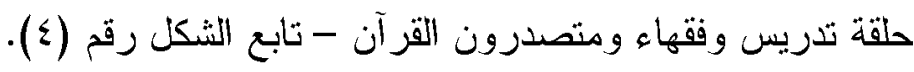
المساجد: مسجد باب الخوخة: يقع هذا المسجد تجاه باب الخوخة بجوار مدرسة أبي غالب بني عام .70017

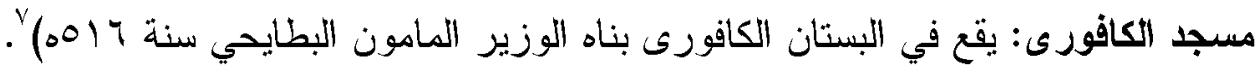

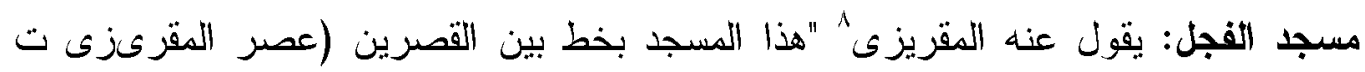

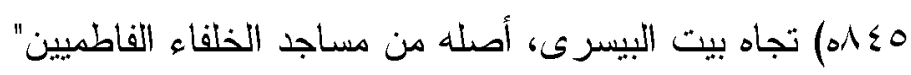
المسجد الحسىنى: يذكره ابن عبد الظاهر ويقول " فأفرد له حجرة من القصر (الكبير) وبناها

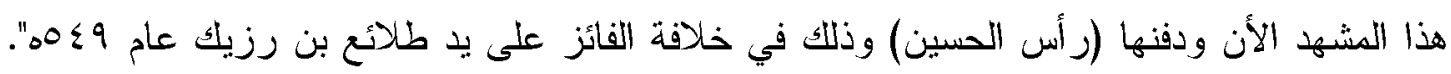

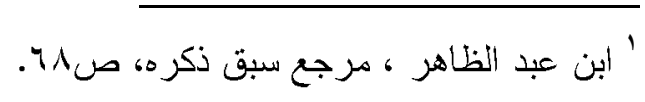

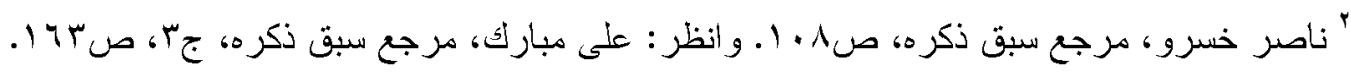

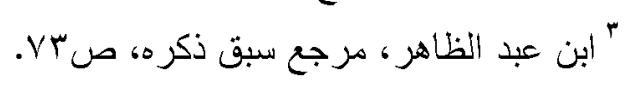

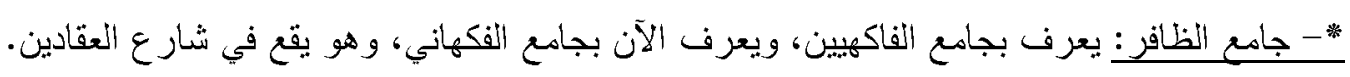

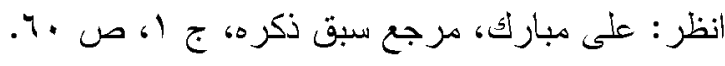

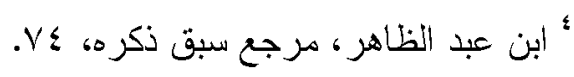

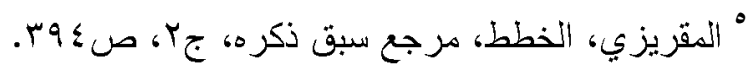

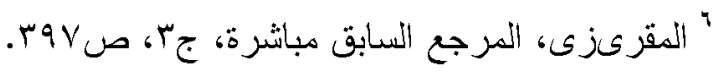

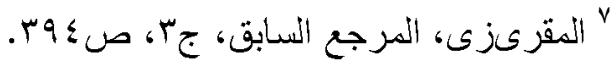

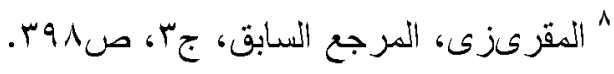


بناء الفائز بنصر اله (ت عام ه000) داخل باب الديلم أحد أبواب القصر الكبيرج - تابع الثكل رقم

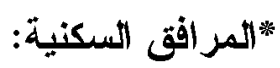

القصور:

القصر الصنير الغربي: أنثأه العزيز بالذه عام .0؛ ه، ويقع تجاه القصر الكبير من جهته

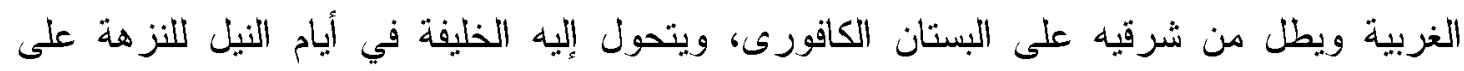

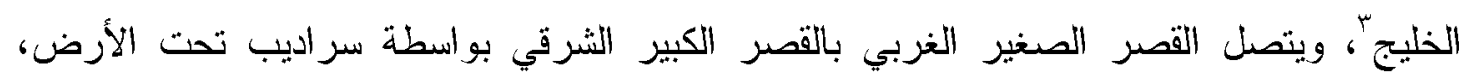

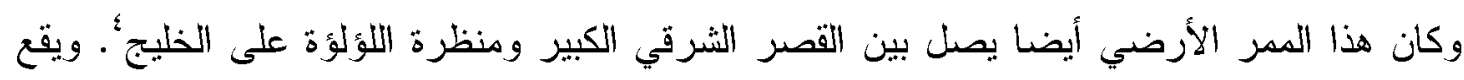

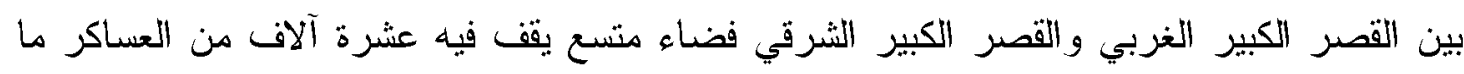

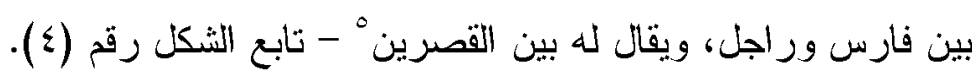
المناظر ":

منظرة اللؤلؤة: وتقع بالقرب من قنطرة باب القنطرة وهي أشهر مناظر الفاطميين، وكانت

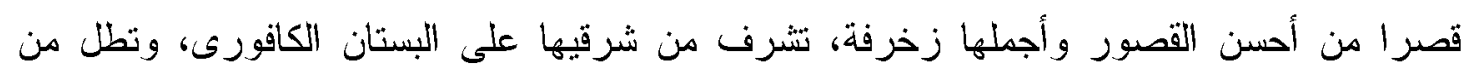

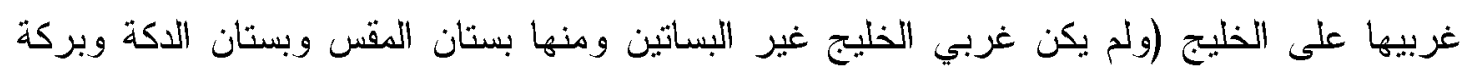

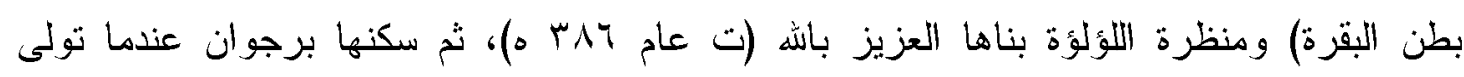

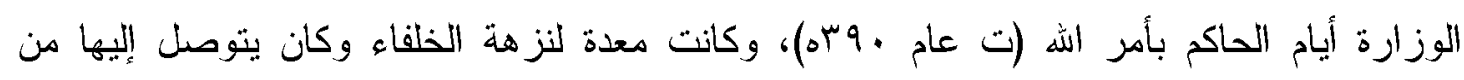

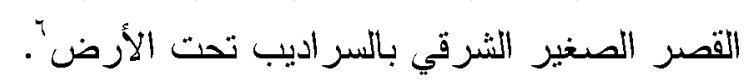

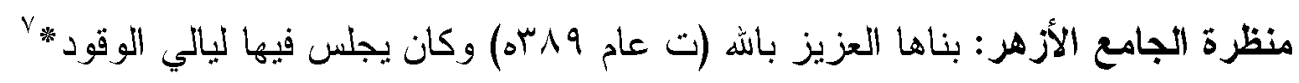

$$
\begin{aligned}
& \text { ' 'ابن عبد الظاهر ، مرجع سبق ذكره، ص.ب-r-r. }
\end{aligned}
$$

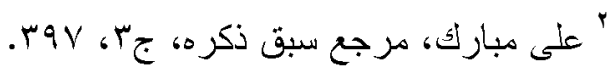

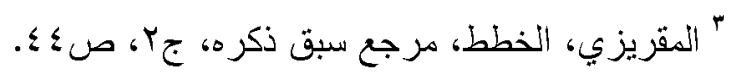

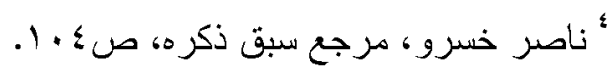

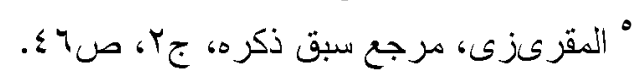

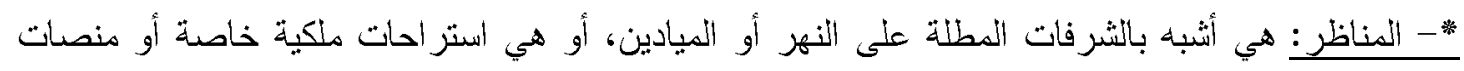

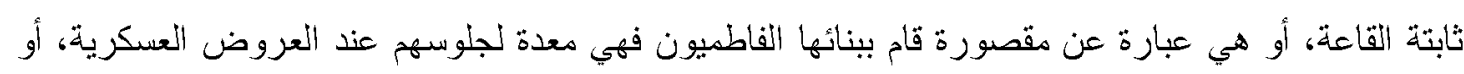

معدة للتزويح وتبني على مشارف الحاضرة الفاطمية.

انظر : حسن إير اهيم حسن، تاريخ الدولة الفاطمية، الطبعة الثانية، مكتبة النهضية المصرية، القاهرة، 1901 1،

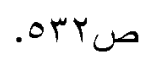

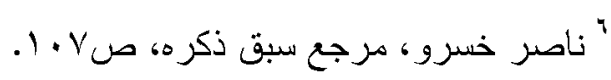

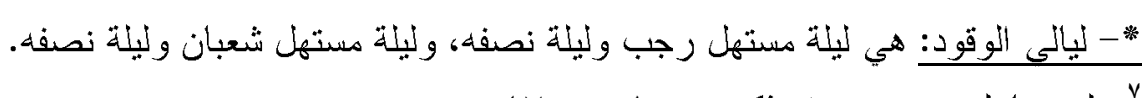

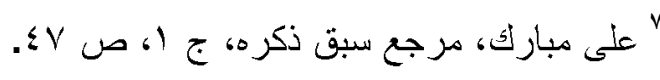




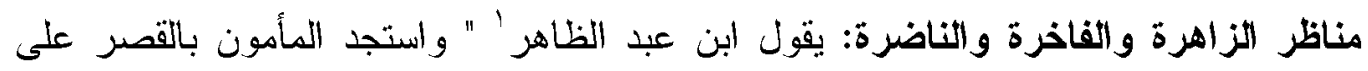

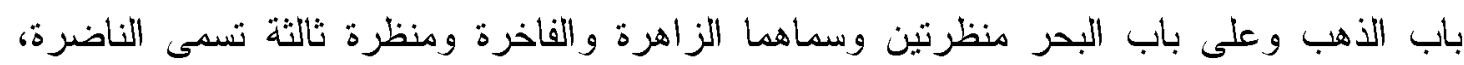

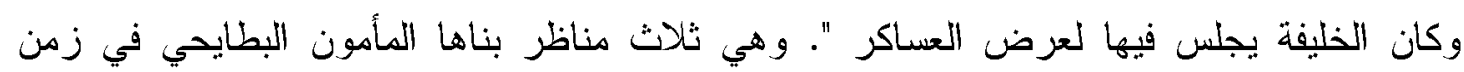

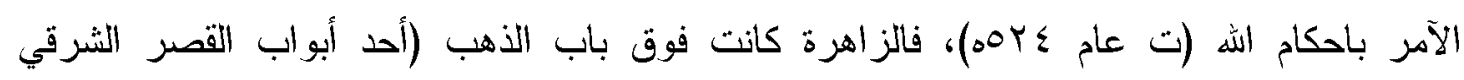

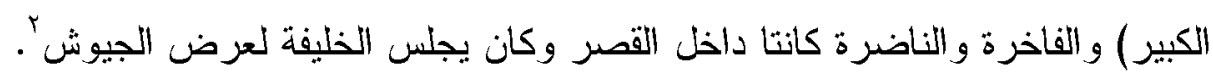
الدور الكبيرة (الأدر):

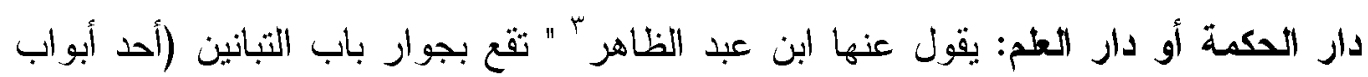

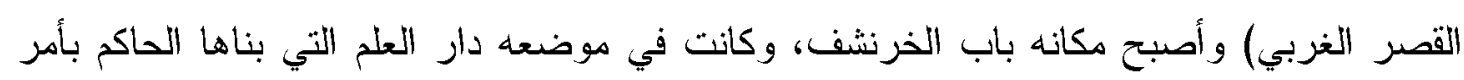

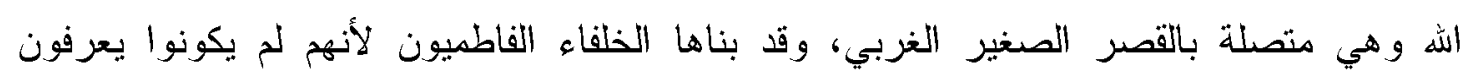

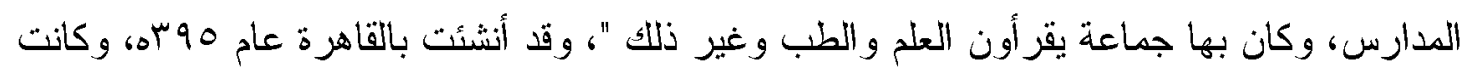

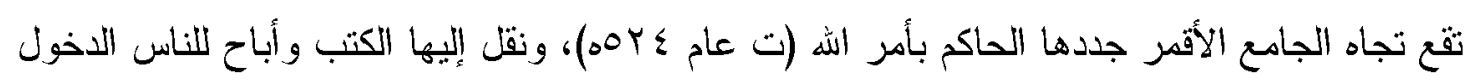

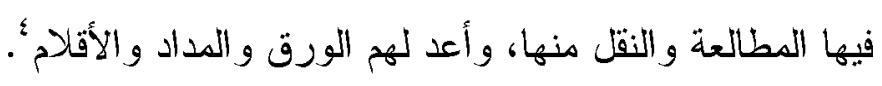

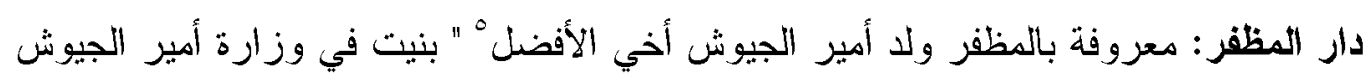

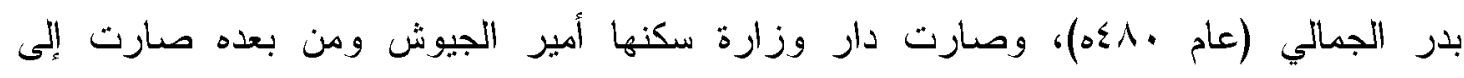
برجوان'

دار ملوخيا: بناها ملوخيا غلام الحاكم بأمر اله (ت عام ؟بهم) (ومحلها الآن درب ملوخيا

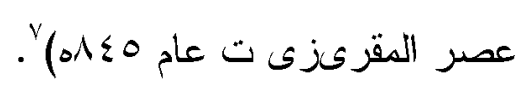

ألدار الأفضلية: بناها الأفضل بن أمير الجيوش بدر الجمالى، ثم سكنها أرباب السيوف وأمراء

الجيوش المصرية، الأية دار الذهب: بناها الأمر بأحكام اله بخط بين السورين (عصر المقرىزى ت عام

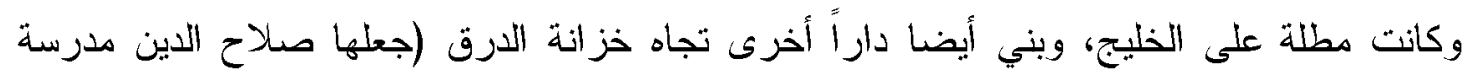
عرفت بالمدرسة السيو فية'.

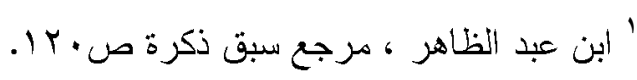

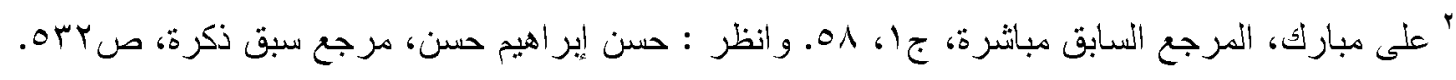

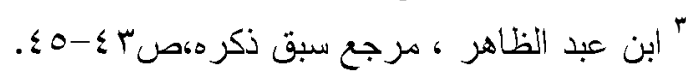

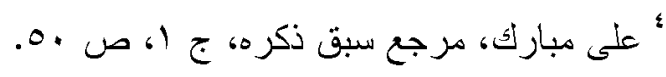

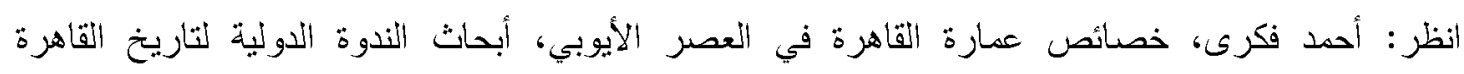

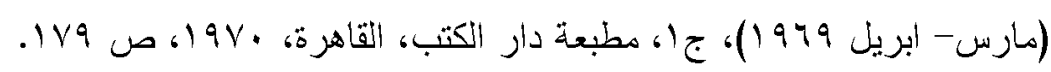

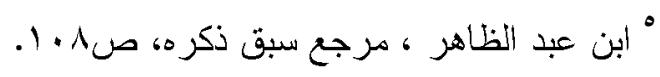

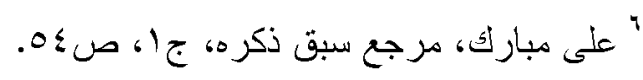

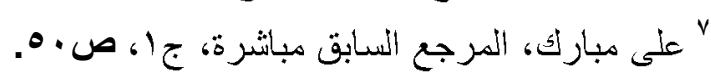

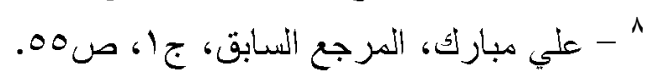


دار الضرب": يقول عنها ابن عبد الظاهر r " وفي أيام المأمون بن البطائحى بنىت دار

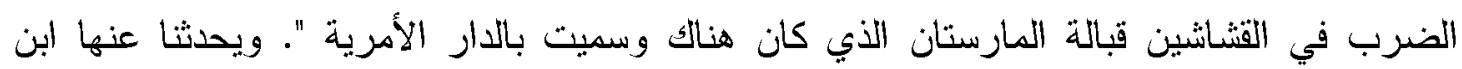

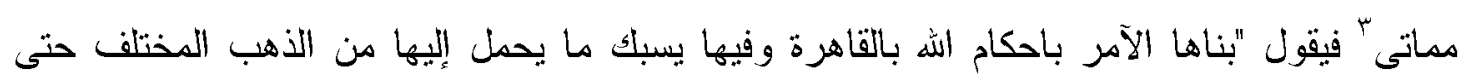

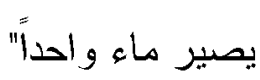
دار الضيافة: يقول عنها المقرىىى" "تقع بحذاء رحبة باب العيد وهي الدار المعروفة بدار

سعىد السعداء" تابع الثكل رقم (؛ ).

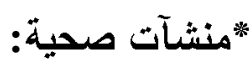

البيمارستان": وقد ذكره السسيحيْ في أحداث عام

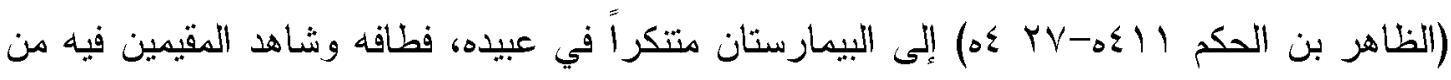

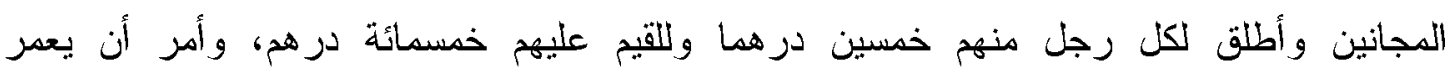

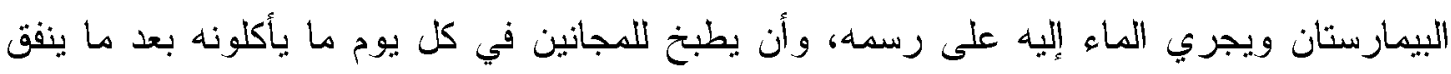
عليهز فيما بستعطونه من الأدوية والأشربة".

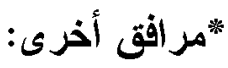
خزائن القصر الكبيز الثرقي: يحدثا عنها المقرىزى فيقول "خزانة الكتب وخزانة البنود

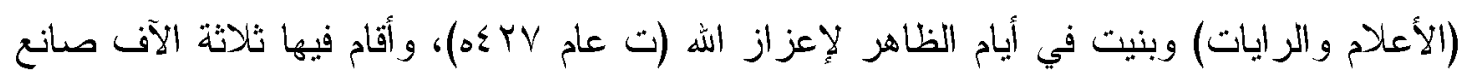

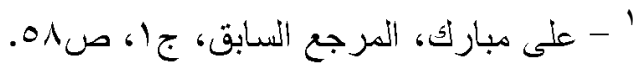

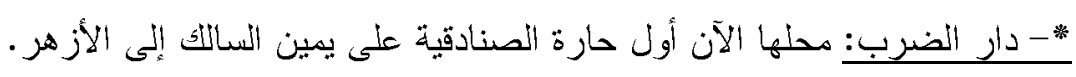

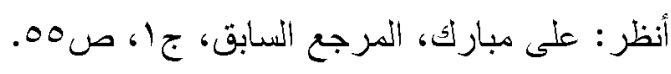

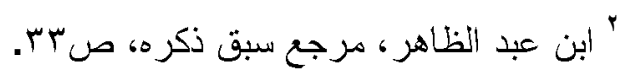

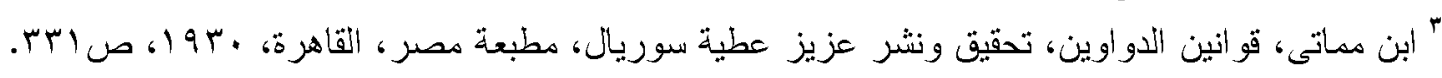

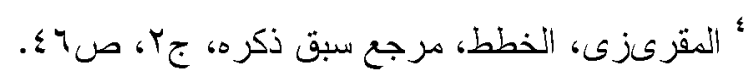

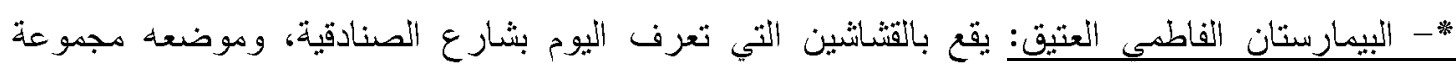
المباني الو اقعة المئان

تجاه جامع الأثرن برسباى بشار ع الأشرفية حيث كان بابه على اليسار بداخل شار ع الصنادقية تجاه دار

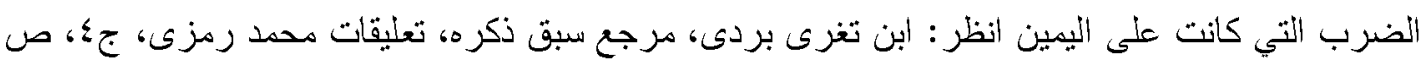
.1 .1

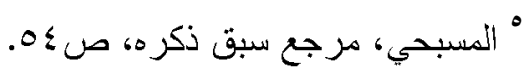

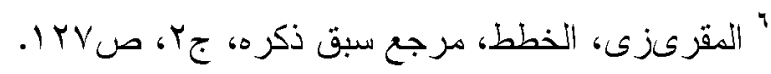

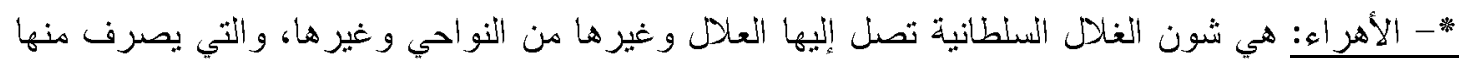
على الاصطبلات الثريفة و المناخات السلطانية. 


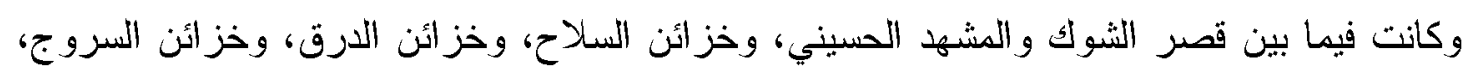

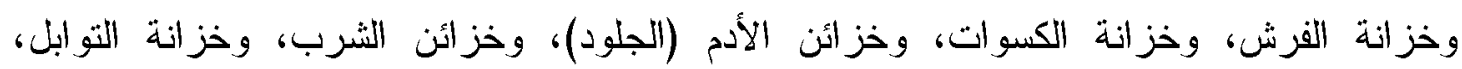
وخز ائن الخيم، وخز انة الجوهز وخر والطيب". الإهراء": يقول عنها الهقرىزى' تقع بجوار الجامع الحاكمى من جهته الغريبة وهي أهراء

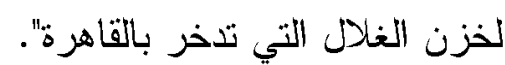

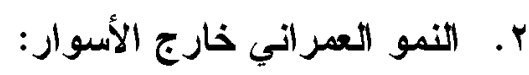

أ. النمو العمر اني جنوب مدينة القاهرة خارج الأنو الأسوار في العصر الفاطمي:

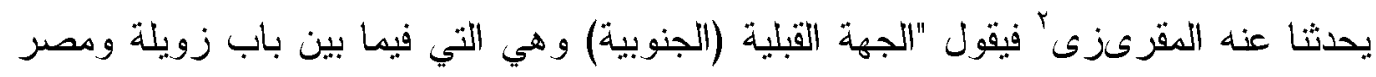

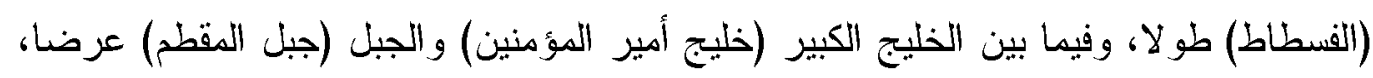

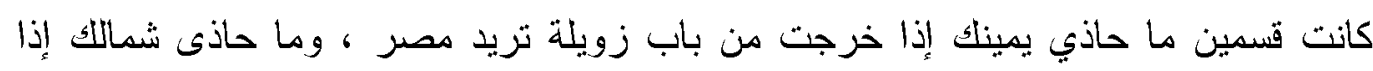

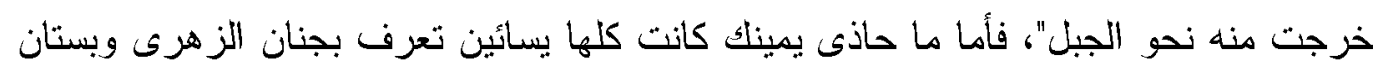

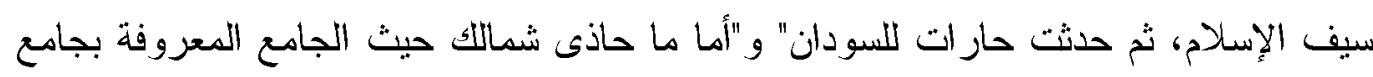
الصالح إلى قطائع ابن طولون فذللك كان مقابر أهل القاهرة".

*أهم المنشآت التي أقيمت في مدينة القاهرة خارج الأسوار جنوبأ:

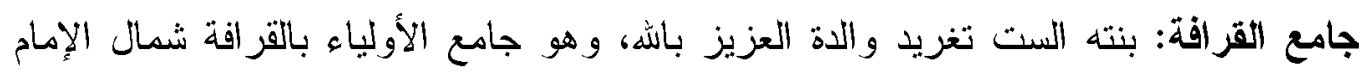

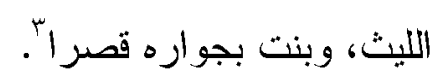
جامع الصالح طلامع: يقول عنه ابن عبد الظاهرء" هو جامع الصالح طلائع بن رزبك خارج

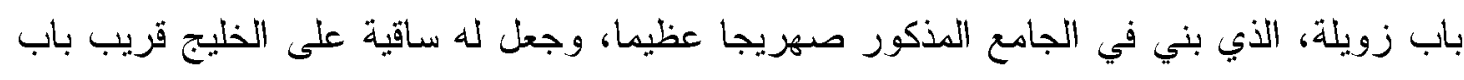

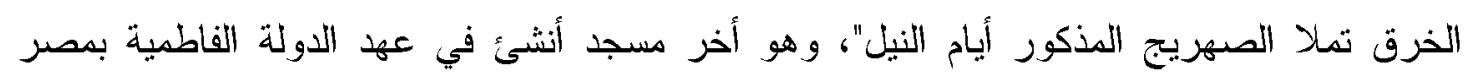

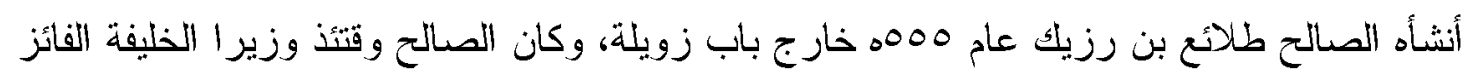
بنصر الله.

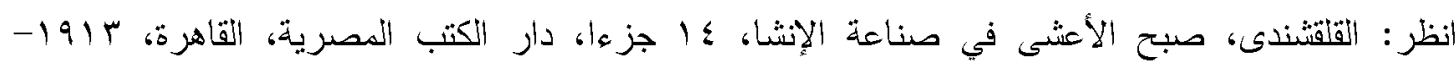

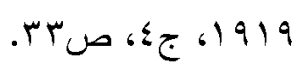

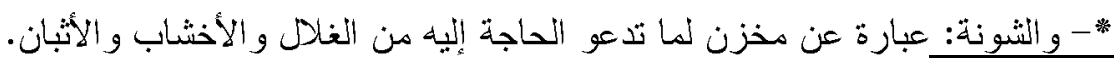

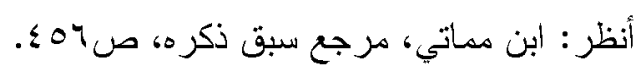

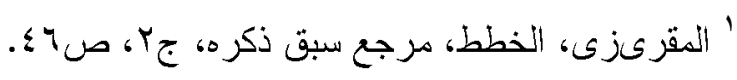

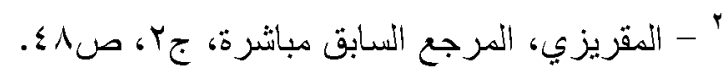

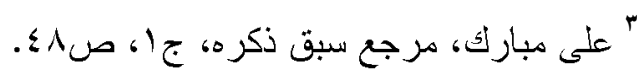

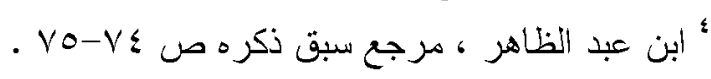

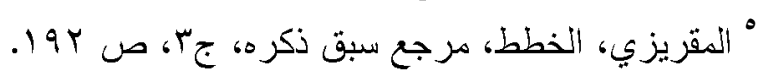




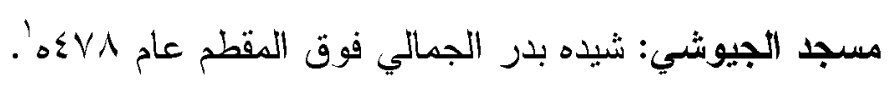

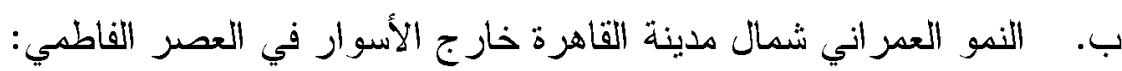

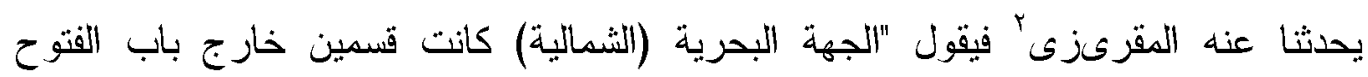

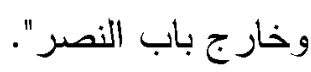
"فأما خارج باب الفتوح فإنه كانت هناك منظرة من مناظر الخلفاء وقدامها البستانان الكبيران،

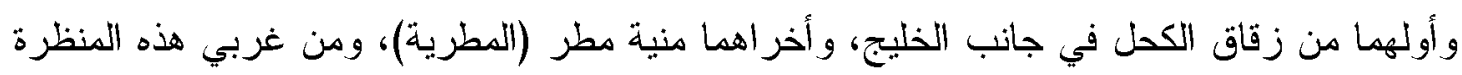

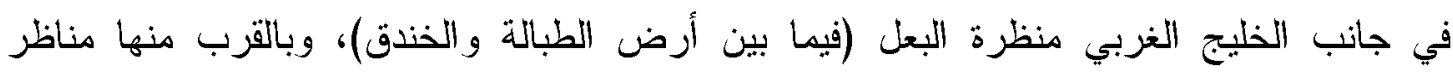
الخمس وجوهو التاج ذات البساتين الأنيقة المنصوبة لتنزه الخليفة".

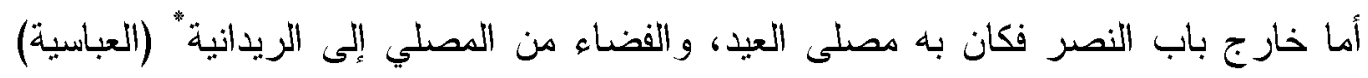

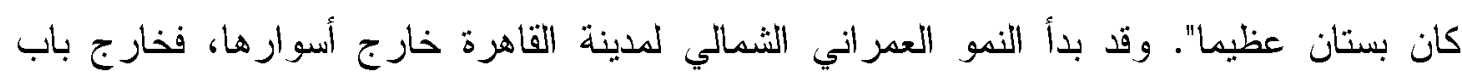

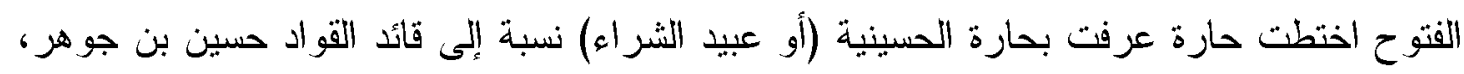

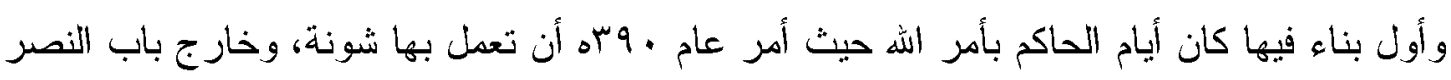

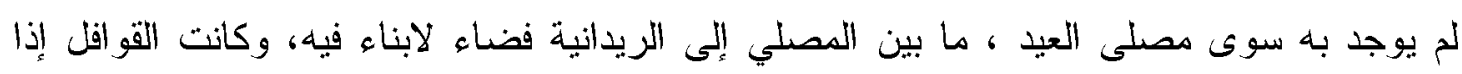

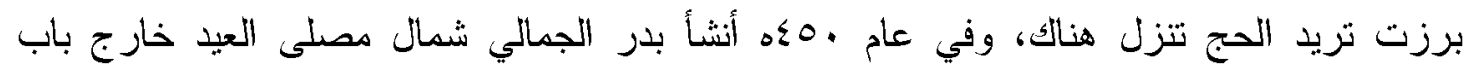

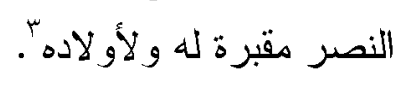

*أهم المنثآت التي أقيمت في مدينة الثاهرة خارج الأسوار شمالاً:

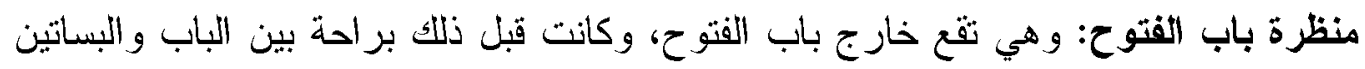

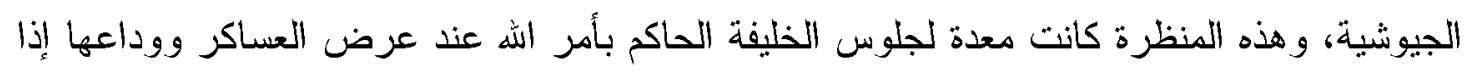

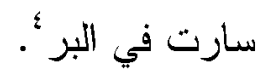

منظرة البعل: أنشاها الأفضل شاهنشاه بن أمير الجيوش بدر الجمالي، وتقع هذه المنظرة

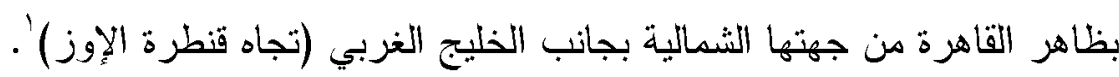

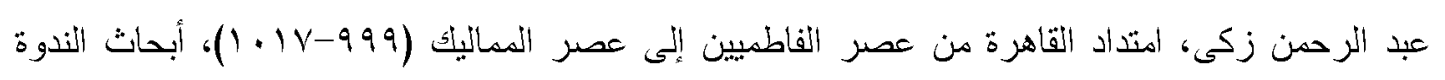

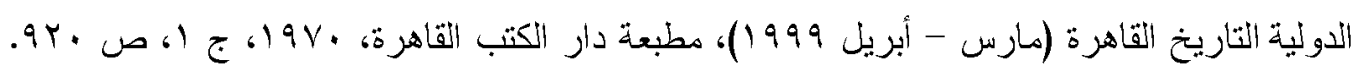

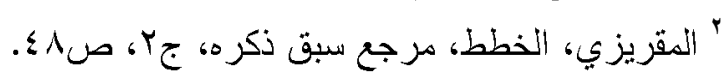

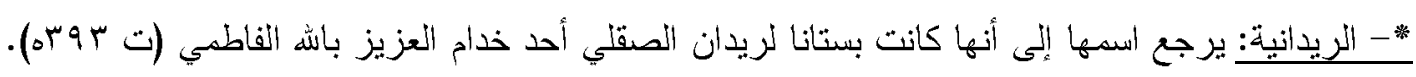

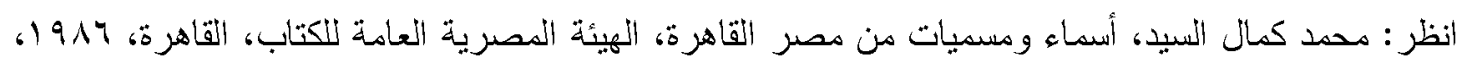

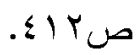

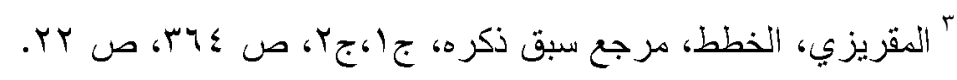

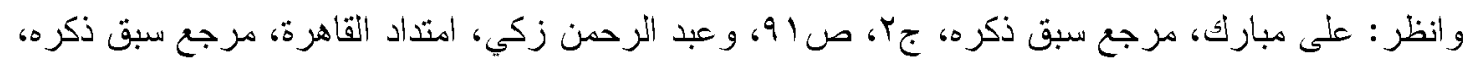

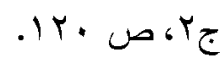

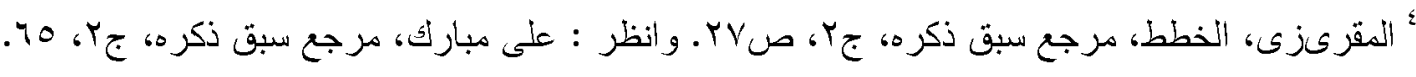


منظرة التاج" والخمس وجوه: يقول عنها ابن عبد الظاهر ب " كان منتز ها وحوله من البساتين

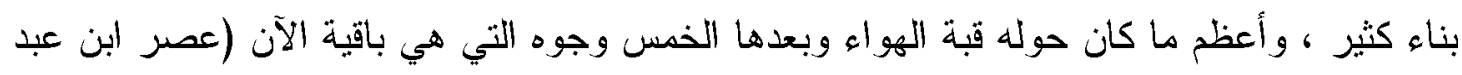

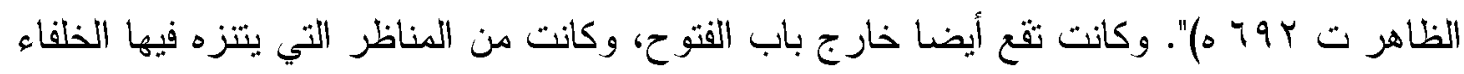

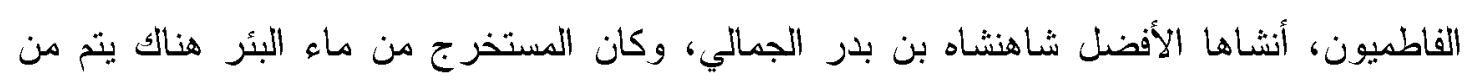

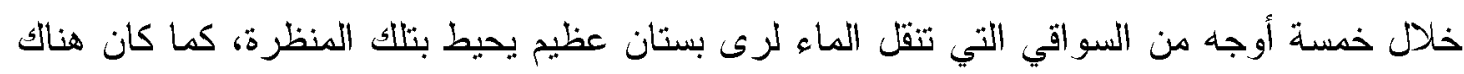

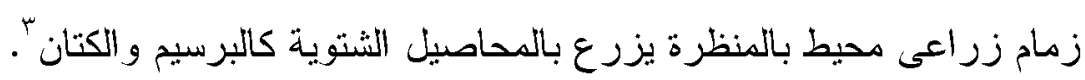

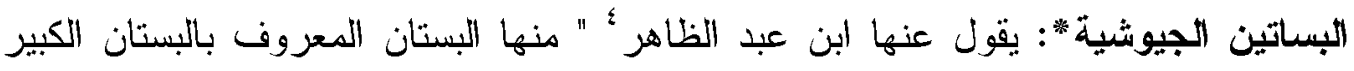

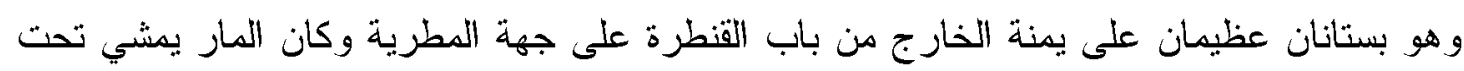

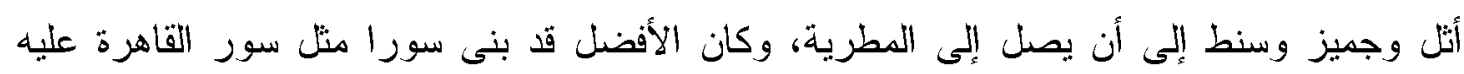

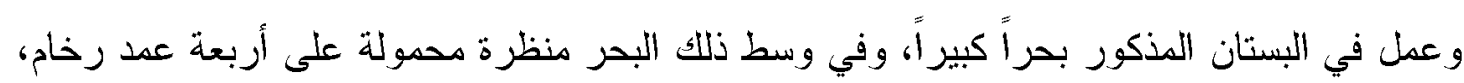

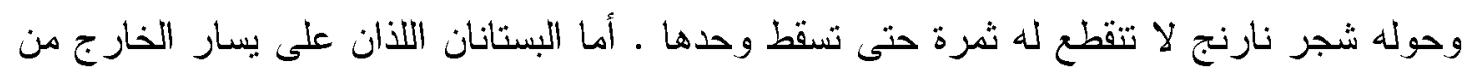

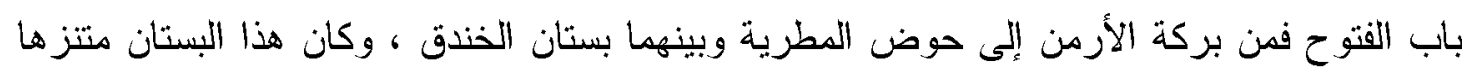

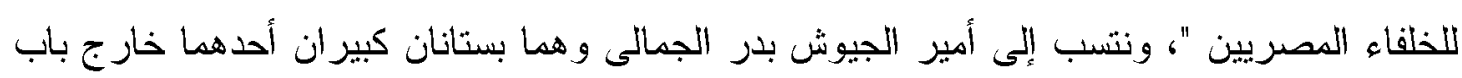

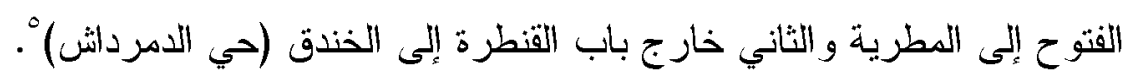

النمو العمراني غرب مدينة القاهرة خارج الأسوار في العصر الفاطمي: ج

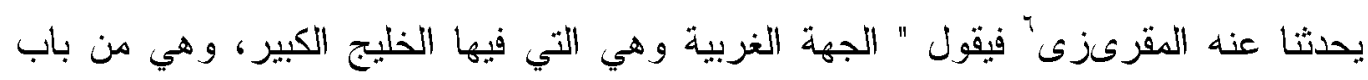

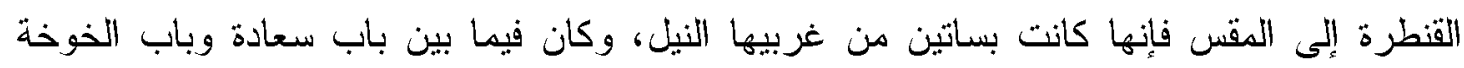

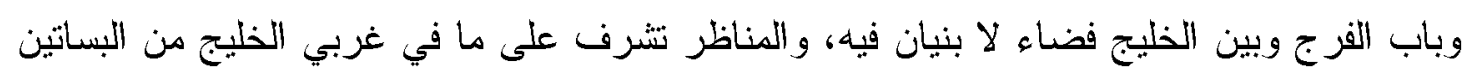

$$
\text { التي ور اءها بحر النيل". }
$$

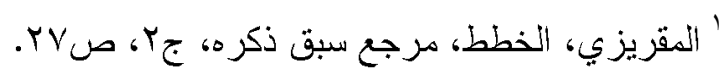

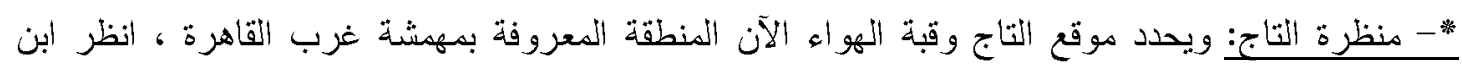

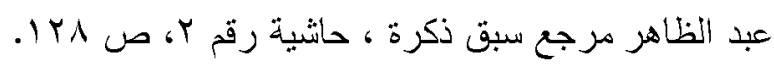

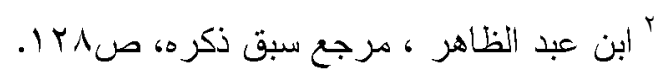

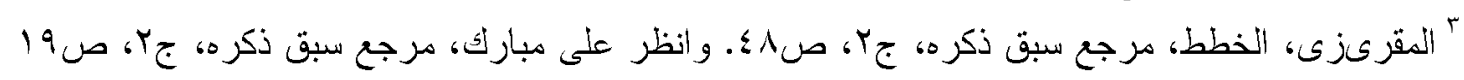

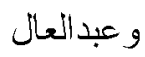

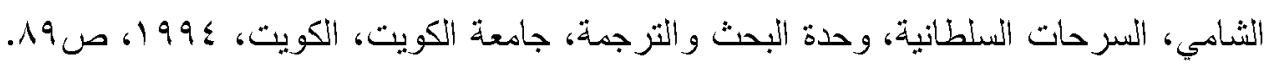

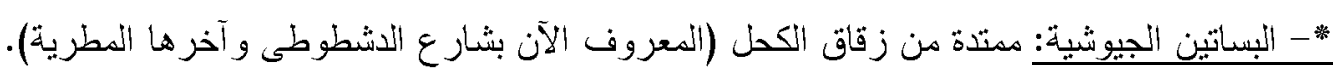

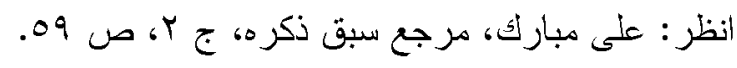

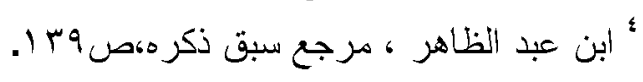

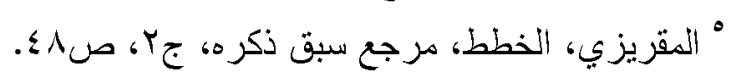

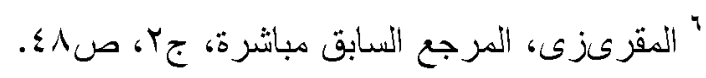


وقد بني المعز لدين اله (ت عام هب؟ه) مرفأ جديدا للسفن في المقس، (وهي قرية قديمة

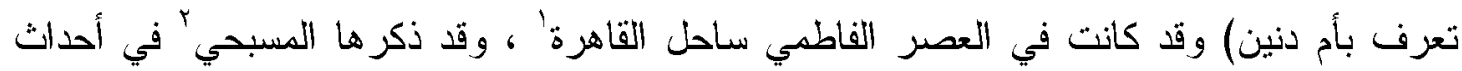

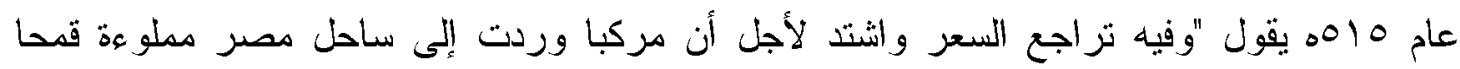

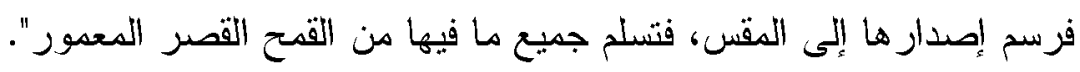

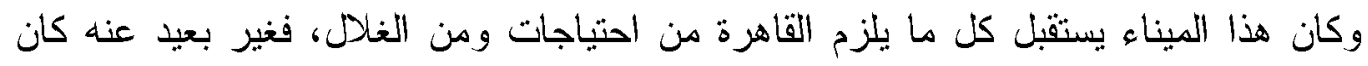
مىدان القمح (هىدان الغلة) وكان موضعا للغلال وغيرها توضع من جانب المقس إلى باب القنطرة

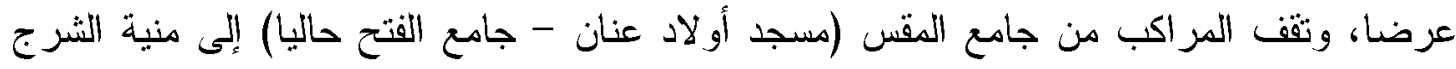

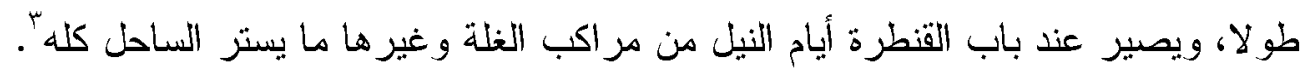

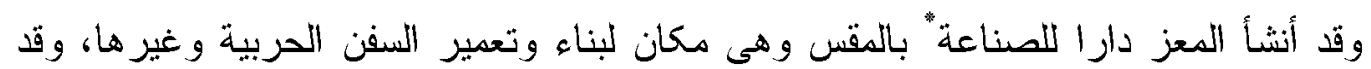

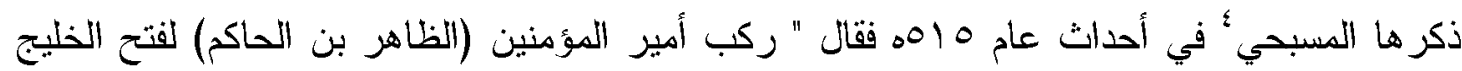
وشق البلد حتى انتهى إلى صناعة الجسر".

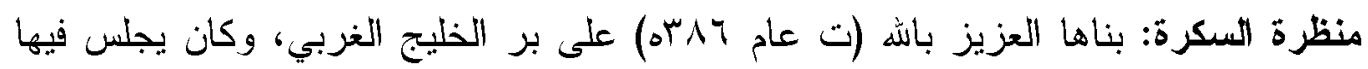

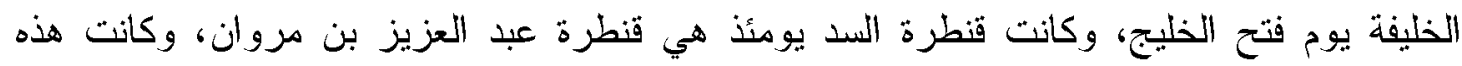

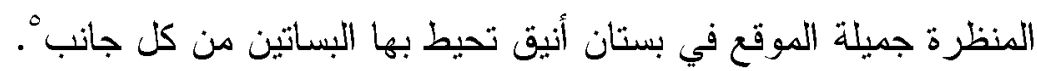

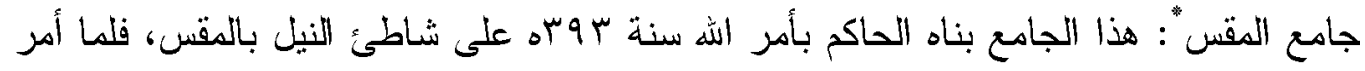

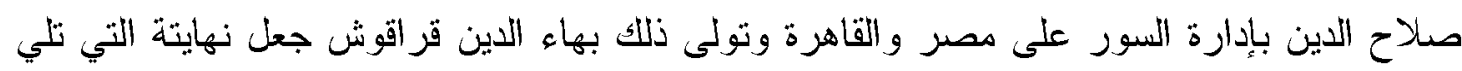

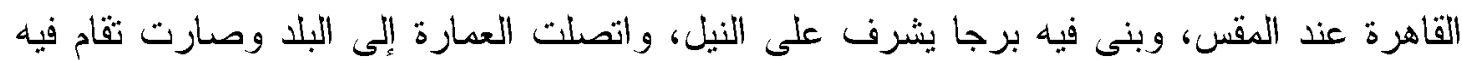

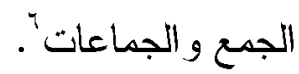

' عبد العال الثشامى مصر عند الجغر افيين العرب، مرجع سبق ذكره، ص

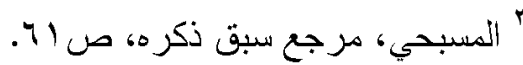

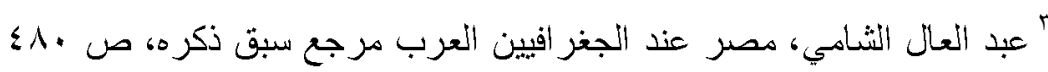

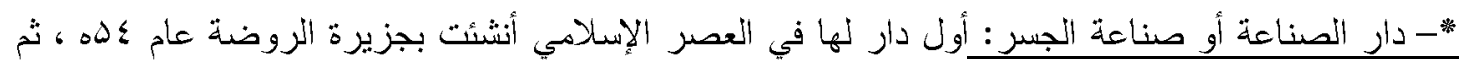

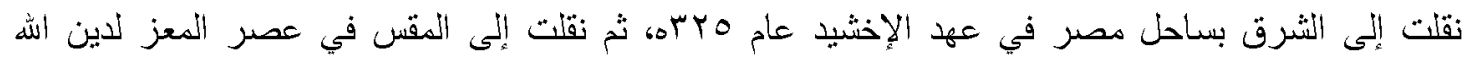

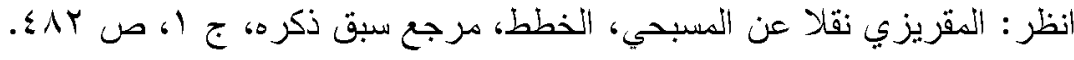

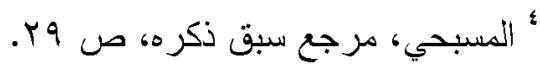

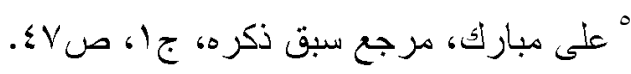

*- المقس: كانت تقع بين باب القنطرة وشاطئ النيل في المكان الأبي يقع فيه الآن جامع أو لاد عنان (مسجد الفتح الآن) أبي في المنطقة المحاطة بشار ع نوبار باثـا وشار ع الفجالة وحديقة الأزبكية.

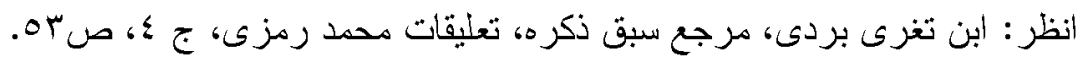

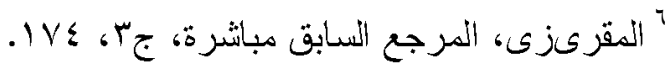




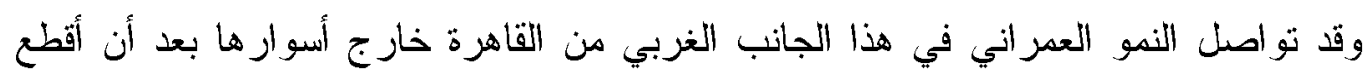

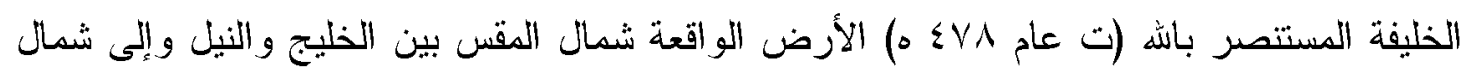

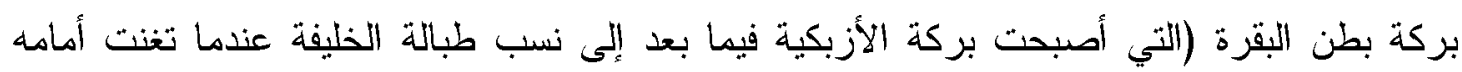

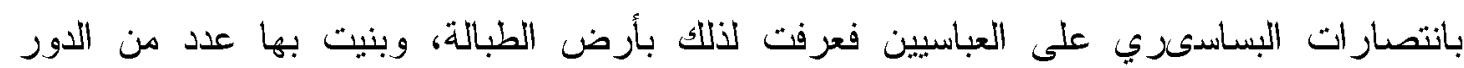
والبيوت'.

وفي عصر الخليفة الأمر بأحكام الله (ت عام ؟به) قام وزيره المامون البطايحي بإعادة حفر

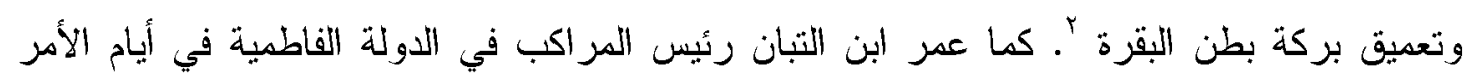

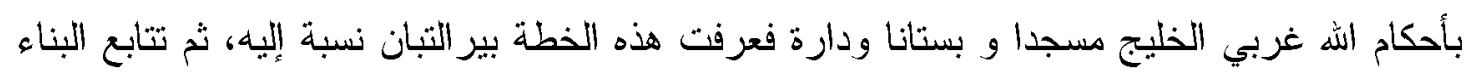
هناك".

منظرة الغزالة* : يقول عنها ابن عبد الظاهر؛ هي على شاطئ الخليج قبالة حمام بن فرقة ".

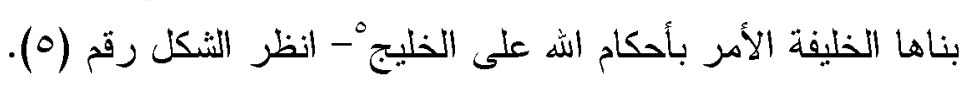

د. النمو العمراني شرق مدينة القاهرة خارج الأسوار في العصر الفاطمي:

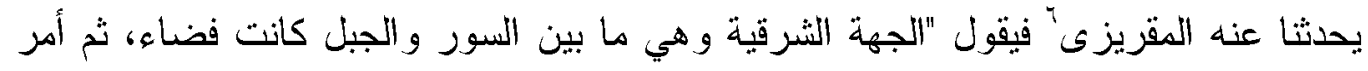

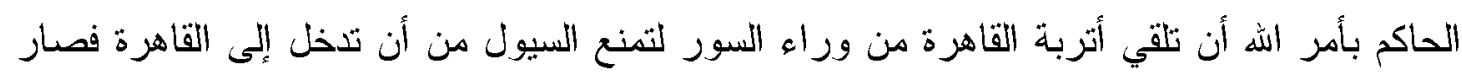

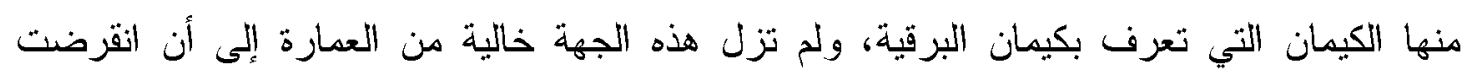
الدولة الفاطية". r. إنكماث نطاق العمران في القاهرة أواخر حكم الفاطميين:

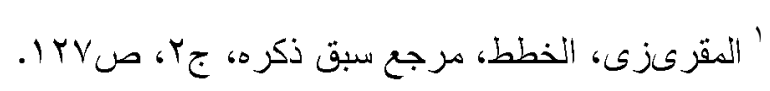

و انظر : جومار، وصف مدينة القاهرة وقلعة الجبل، نقله عن الفرنسية وقدم له و وعلق عليه أيمن فؤاد سيد،

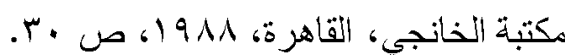

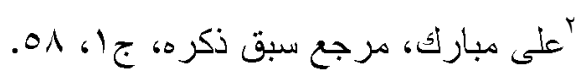

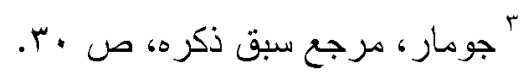

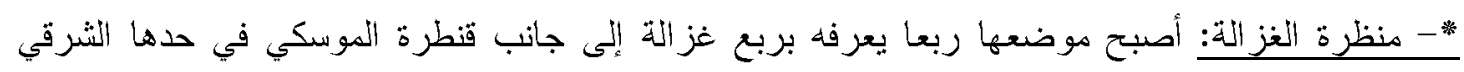

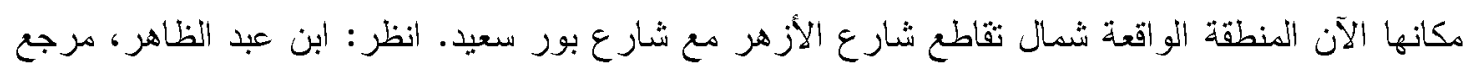

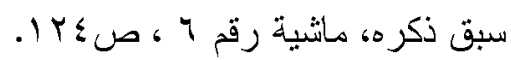

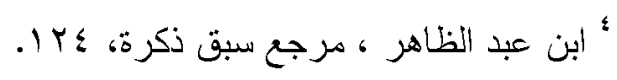

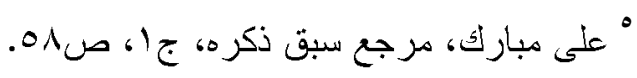

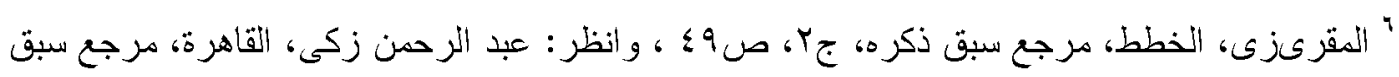

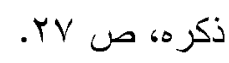


هناك سببان لانكماش نطاق العمران في مدينة القاهرة في العصر الفاطمي وهما الثدة

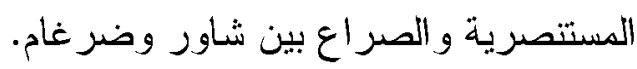

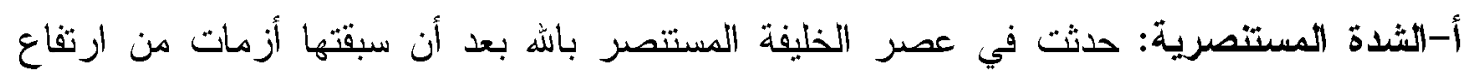

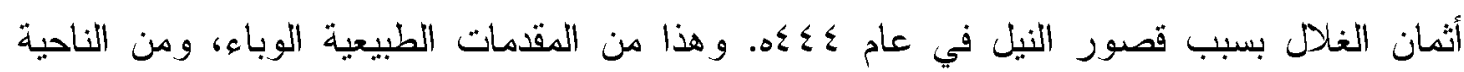

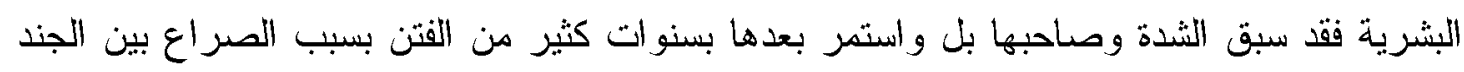

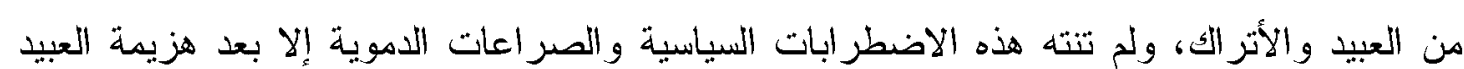

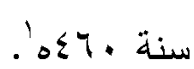

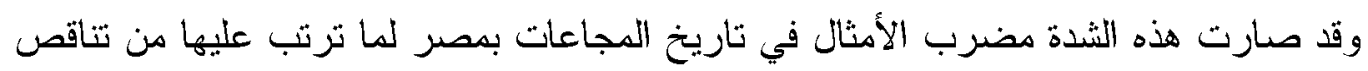

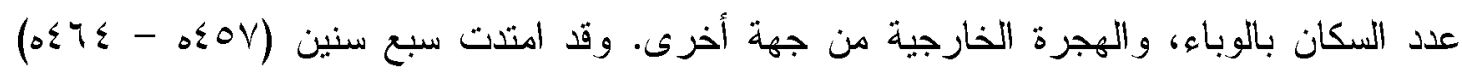

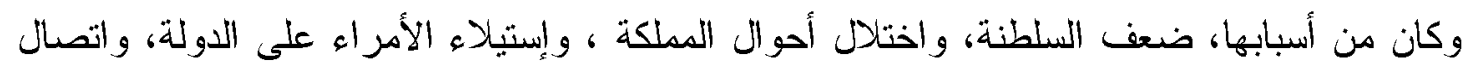

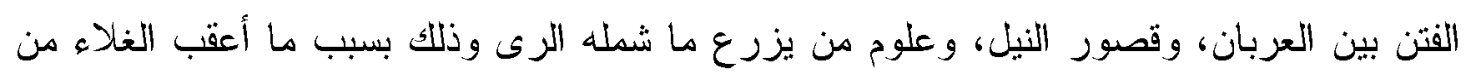

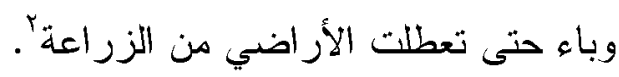

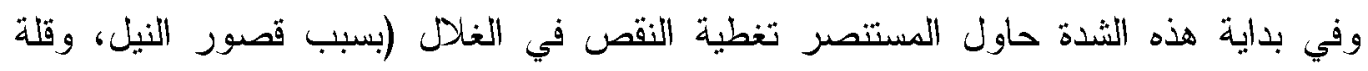

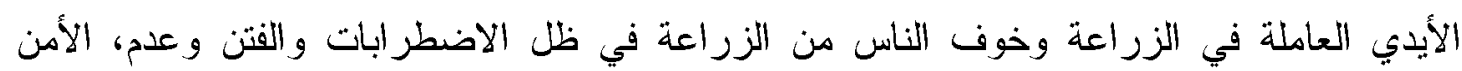

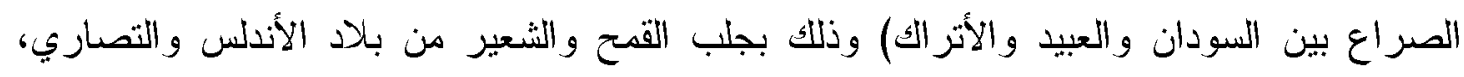

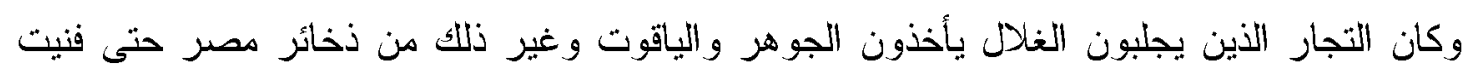

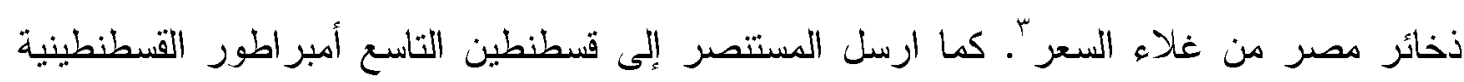

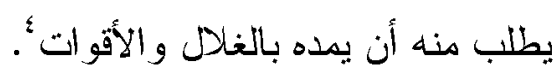

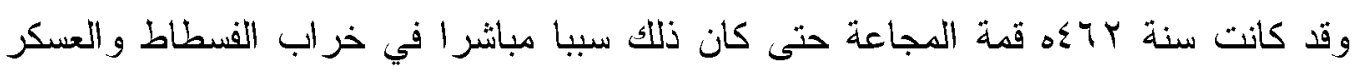

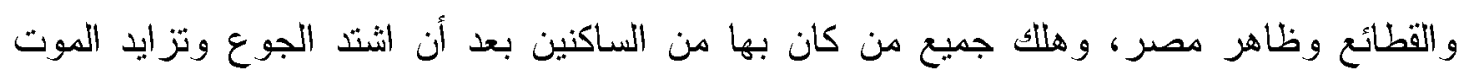

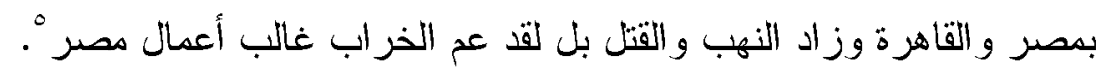

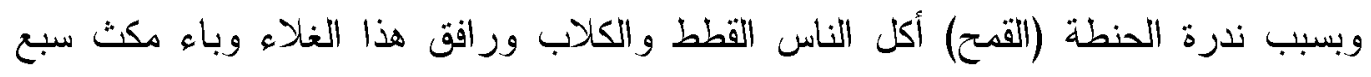

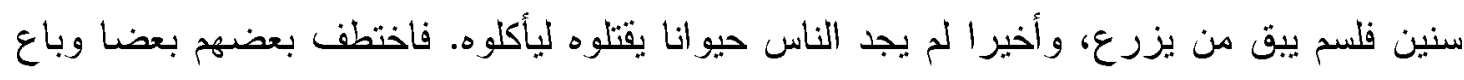

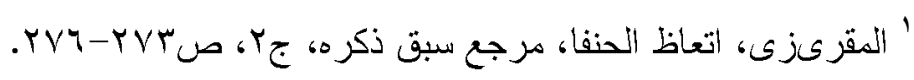

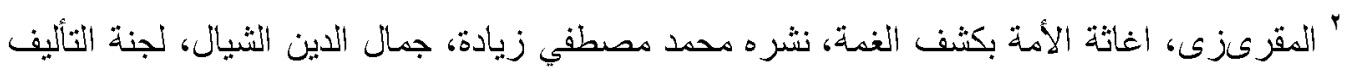

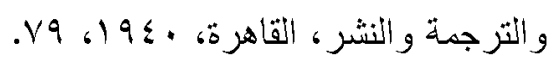

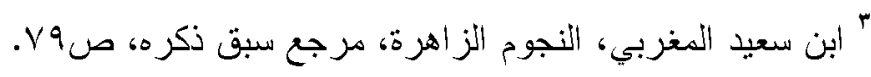

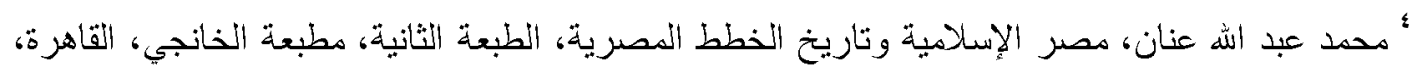


القصابون الجزارون) لحم الإنسان، ثُ جاء الطاعون فكان يحصد أسرة بعد أسرة وقاست مصر في

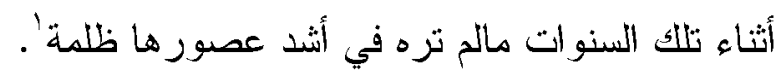

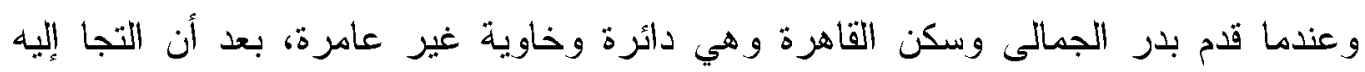

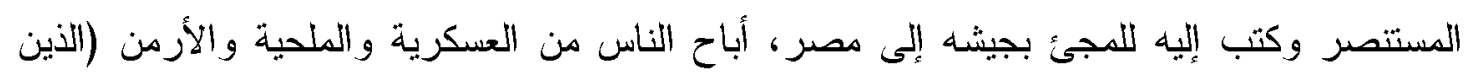

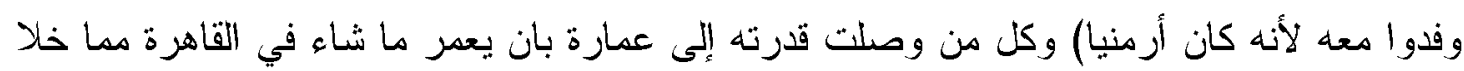

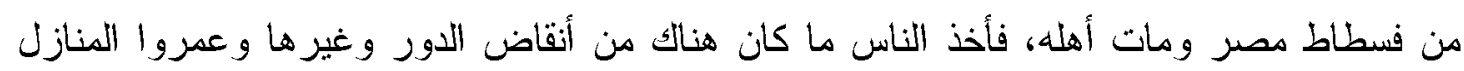
في القاهرة وسكنو هابً.

وبعد تقل أنقاض ظاهر مصر مما يلي القاهرة حيث العسكر و القطائع صار محلها فضاء وتلا"

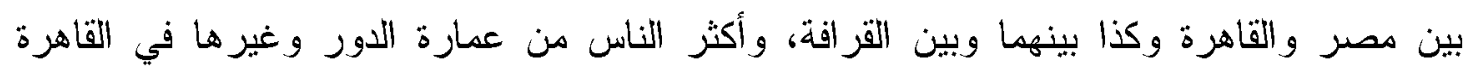

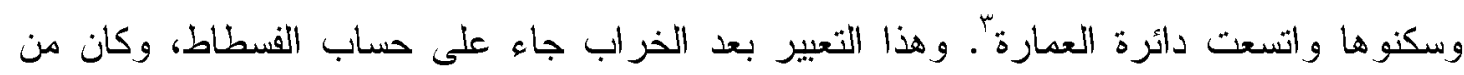

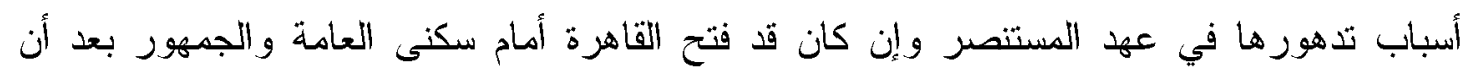

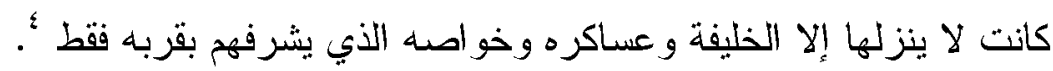

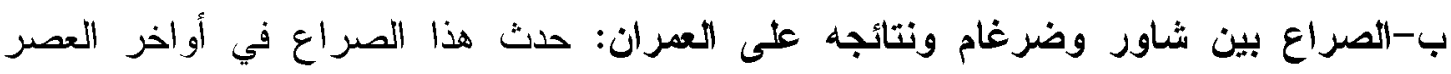

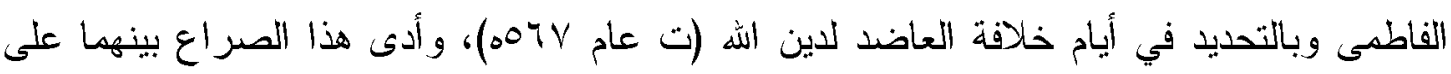

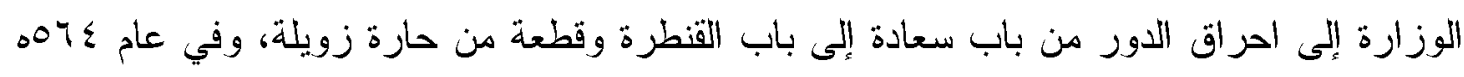

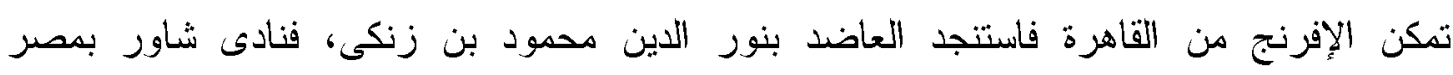

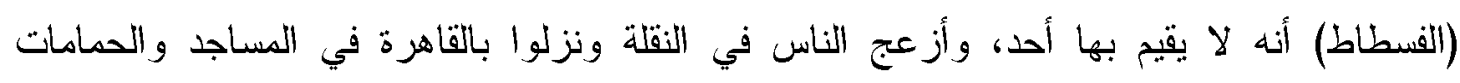
والأزقة و على الطرقات.

و هكذا نجد أن قاهرة المعز وإن شهدت نموا عمر انيا خصوصا في العصر الفاطمي الأول، فإنه في العصر الفاطمي الثاني ومع تدهور الدولة سياسية واقتصادية، تراجع هذا النمو العمراني للقاهرة.

قائمة المصادر و المراجع

أولاً: المصادر:

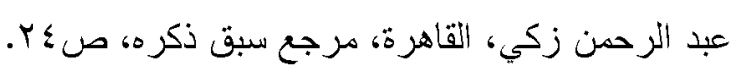

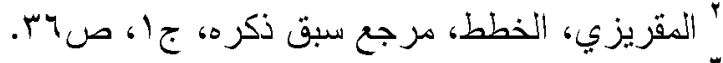

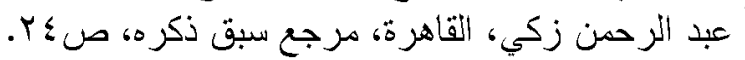

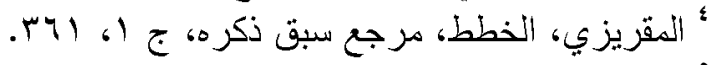

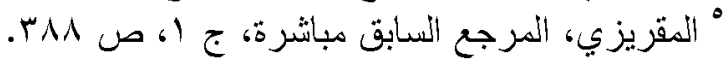


1- ابن تغرى بردى، النجوم الز اهرة في ملوك مصر و القاهرة، 9 اجزعا، الأجزاء من ا-1Y|

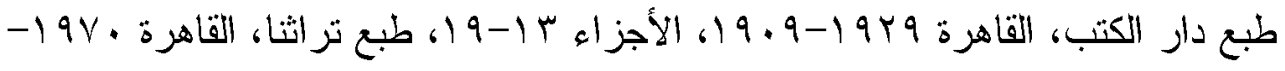

$$
.11 \mathrm{P}^{6} 19 \mathrm{VM}
$$

r- ابن حجر، إنباء الغمر بأبناء العمر، بأجزاء، تحقيق حسن حبشى، المجلس الأعلى للشئون

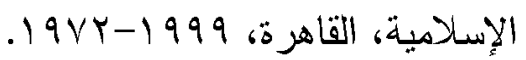

r- ابن حوقل: صورة الأرض، تحقيق كريمرز، طبعة بريل، لَيْدِن، ربهو ا. צ- ابن دقماق، الانتصار لو اسطة عقد الأمصار،جه، دار الآفاق الجديدة، بقروت، د.ت. ه- ابن سعيد المغربي، النجوم الزاهرة في حلى حضرة القاهرة، تحقيق حسين نصار ، مطبعة دار الكتب، القاهرة، . 19V. ج- ابن عبد الظاهر ، الروضة البهية الزاهرة في خطط المعزية القاهرة، حفقه وقدم له وعلق عليه

$$
\text { أيمن فؤاد سيد، بيزوت } 1999 \text { أبرن }
$$

V- الصيرفي، نزهة النفوس و الأبدان في تواريخ الزمان، بأجزاء، تحقبق حسن حبش، دار

$$
\text { الكتب، القاهرة، . 19V. }
$$

^- الظاهرى، زبدة كثف الممالك وبيان الطرق والمسالكك، تحقىق بيول راويس، المطبعة

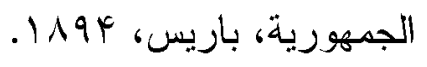

9- على مبارك، الخطط التوفيقية الجديدة لمصر ، ج ا، القاهرة، الهيئة المصرية العامة للكتاب،

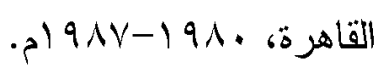

• - - القلقندى، صبح الأعشى في صناعة الإنشا،ج؛، ع ؛ جزعا، دار الكتب المصرية،

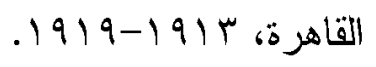

11- محمد رمزي، القاموس الجغر افي للبلاد المصرية من عهد قدماء المصريين "لسنة

19 19 - البلاد المندرسة، مطبعة دار الكتب المصرية، فهرس القاموس الجغر افي الجزء

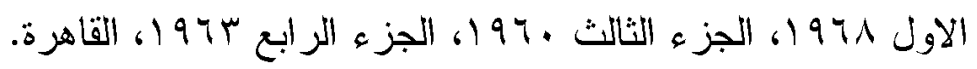

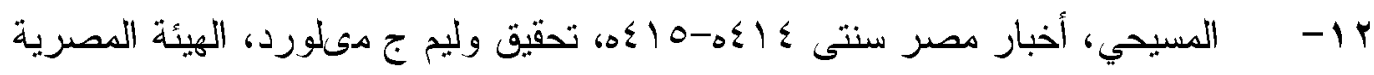
العامة للكتاب، القاهرة، . 191 19. r ب - المقرىزى، أتعاظ الحنفا بذكر الأثمة الخلفا، ب أجزاء، نشر جمال الدين الثيال، محمد

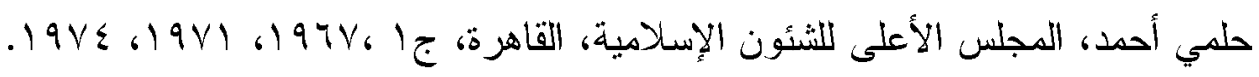


ع ا- المقرىزى، اغاثة الأمة بكشف الغمة، نشره محمد مصطفي زيادة، جمال الدين الثبال، لجنة التأليف و الترجمة والنشر ، القاهرة، . 9 1.

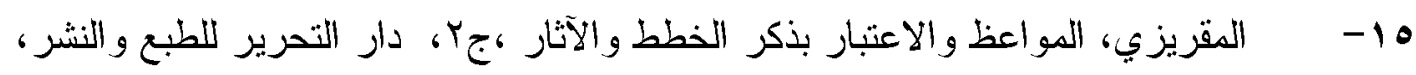

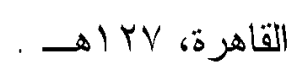

17- اصر خسرو، سفر نامه، ترجمة يحبى الخشاب، الهيئة المصرية العامة للكتاب،

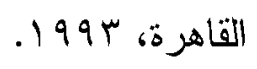

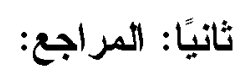

1- أحمد على إسماعيل، العالم الإسلامي، دراسات جغرافية في الجوانب الحضارية، دار

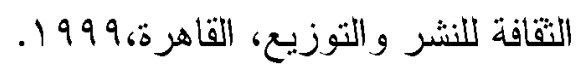

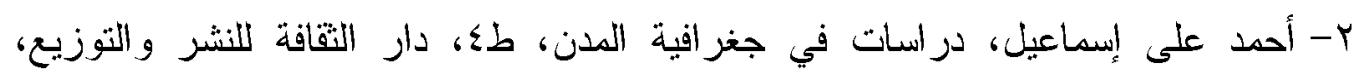

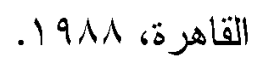

r- أحمد فكرى، خصائص عمارة القاهرة في العصر الأيوبي، أبحاث الندوة الدولية لتاريخ

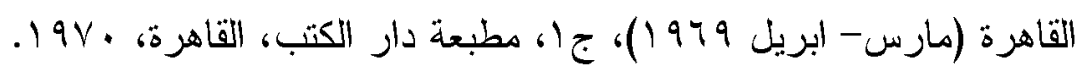

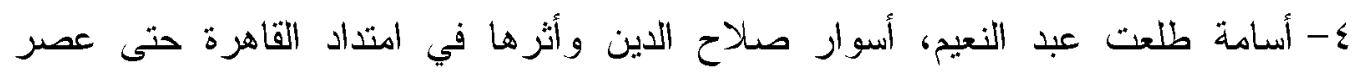

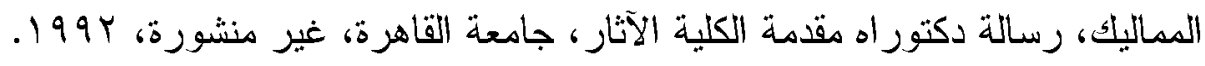

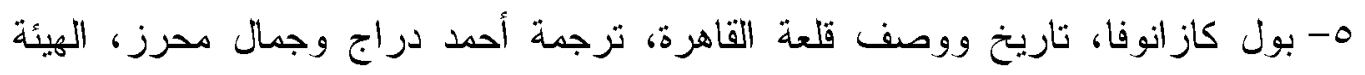

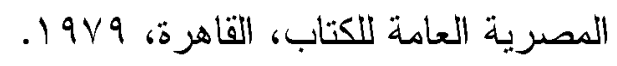
9- جومار، وصف مدينة القاهرة وقلعة الجبل، نقله عن الفرنسية وقدم له وعلق عليه أبمن

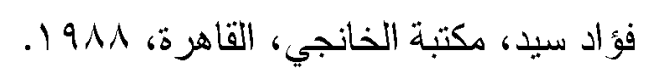
V- حسن إبراهيم حسن، تاريخ الدولة الفاطمية، الطبعة الثانية، مكتبة النهضة الفئهة المصرية،

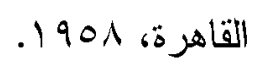

1- صلاح الاين عبد الله بحيرى، صحراء جنوب شرق الألتا دراسة جيمورفولوجيه، رسالة

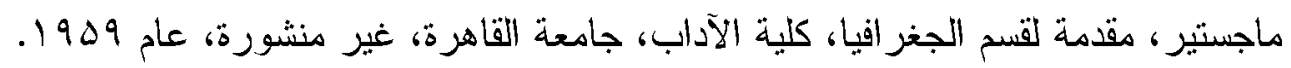

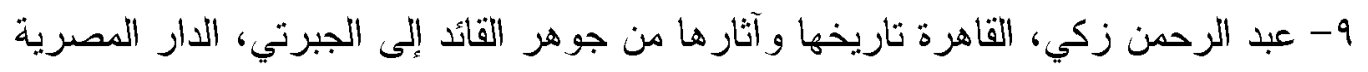
للتأليف، القاهرة، 1974. • 1- عبد العال الثامي، السرحات السلطانية، وحدة البحث والترجمة، جامعة الكويت،

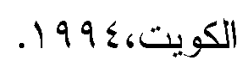

11- عبد العال عبد المنعم الثامى، جغرافية العمران عند ابن خلدون، الجمعية الجغرافية

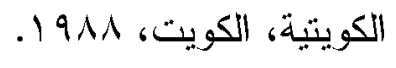


rا- عبد العال عبد المنعم الثامي، مصر عند الجغرافيين العرب فيما بين القرنين الثالث

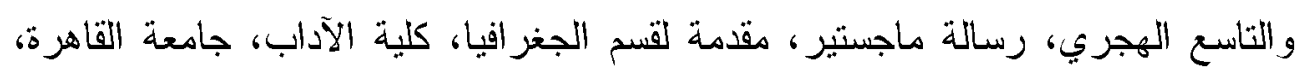

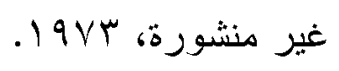

با- على إبراهيم حسن، تارىخ جوهر القائد، الطبعة الأولى، النهضة العربية، القاهرة،

ع ا- فتحي محمد أحمد الثرقاوى، جبل المقط دراسة جيومورفولوجية تطبيقة، معهد البحوث

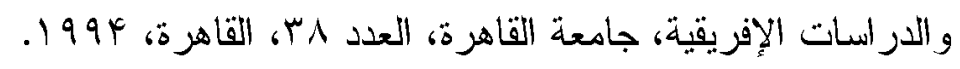

10- فتحى محمد مصيلحى، تطور العاصمة المصرية والقاهزة الكبرى، دار المدينة المنورة،

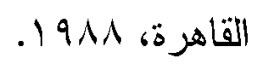

17 - محمد عبد الستار عثمان، المدينة الإسلامية، عالم المعرفة، الكويت، 1911 19.

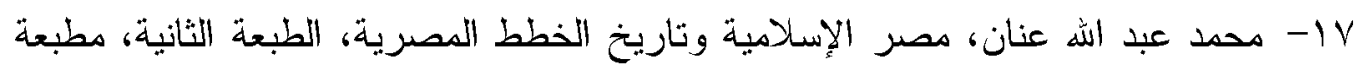

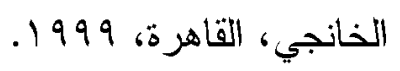

11- محمد كمال السيد، أسماء ومسميات من مصر القاهزة، الهيئة المصرية العامة للكتاب،

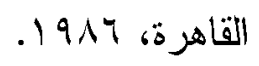

الخاتمة:-

إنصب اهتمام هذه الدراسة لددينة القاهرة فى العصر الفاطمى على استقصاء المادة العلمية من

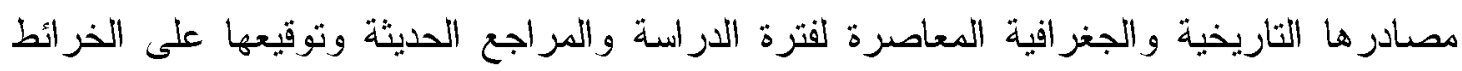

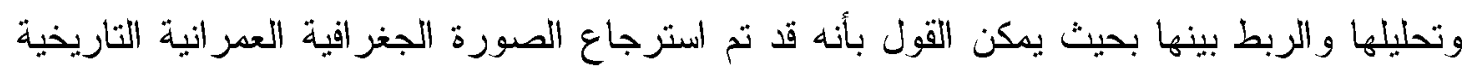

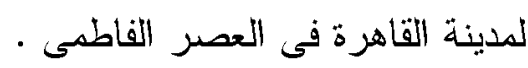
بالنسبة لموضع مدينة القاهرة فلقد توافرت فى نثأتها الاولى مساحة كافية من أراضي طرح النهر

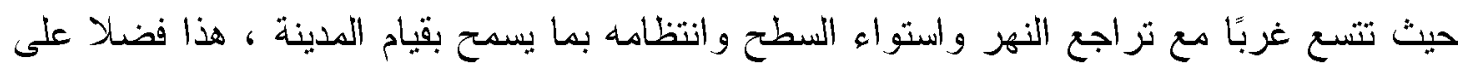

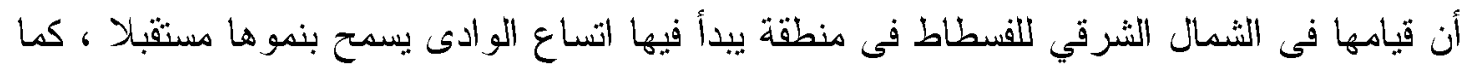

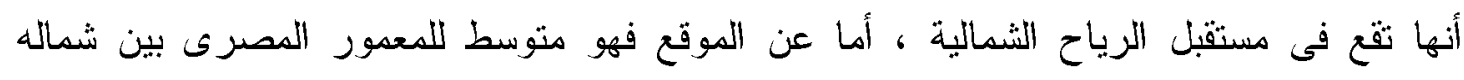

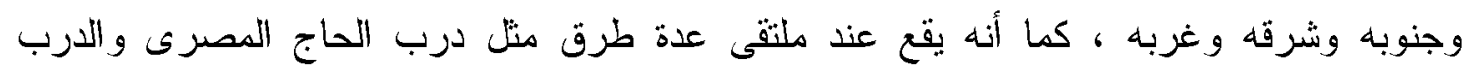

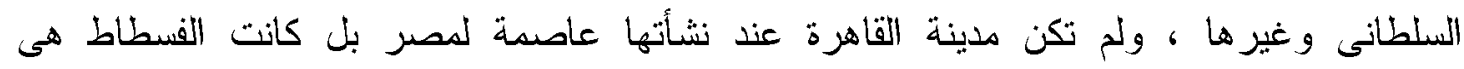

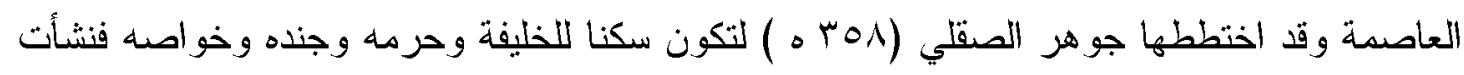

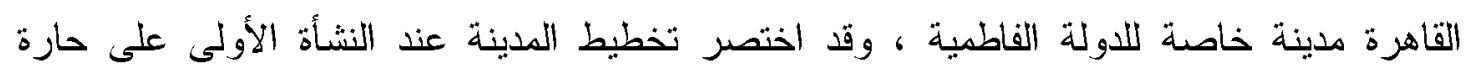

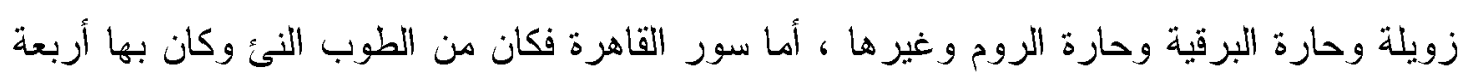

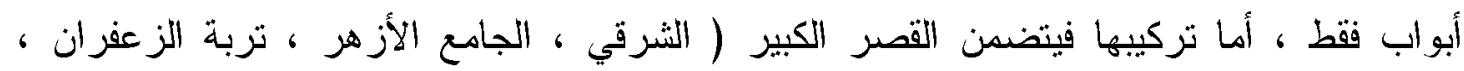
مصلى العيد ) 


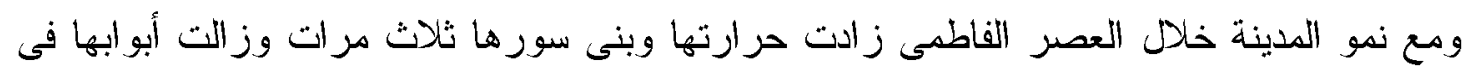

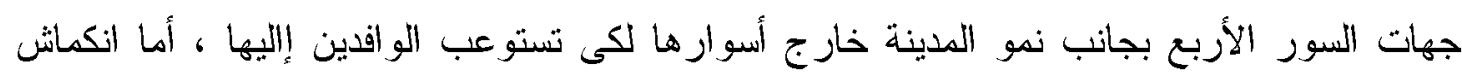

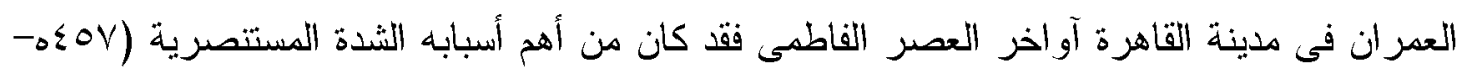

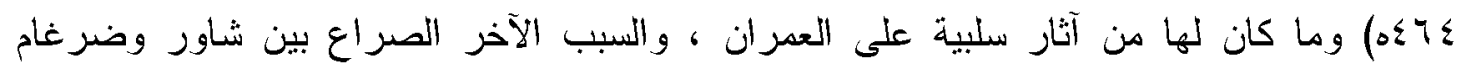

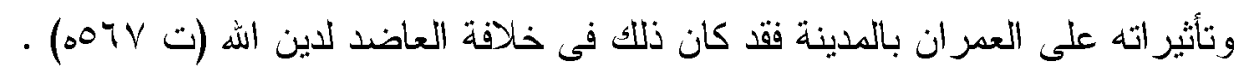

